S B

221

Ho

UC-NRLF

|

В 4 52] 736 


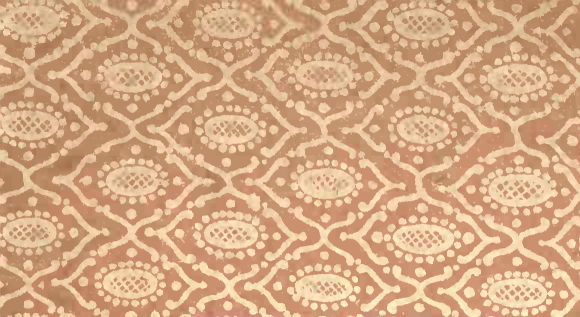




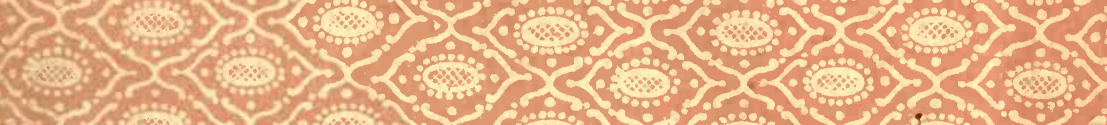

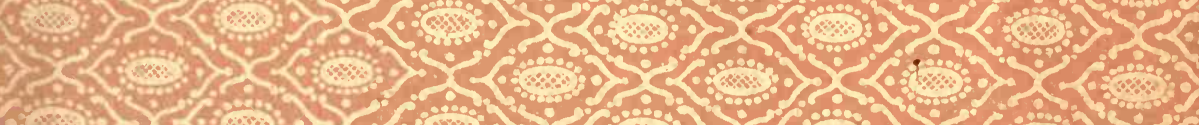

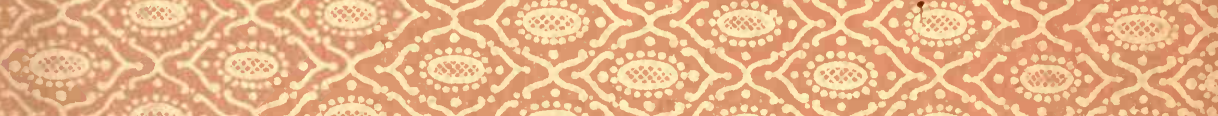

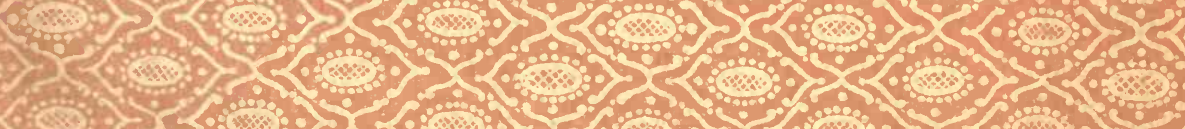

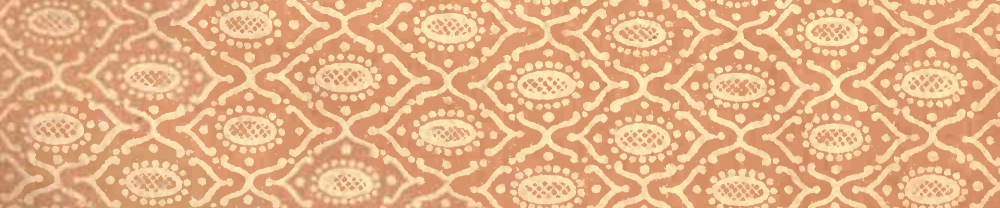

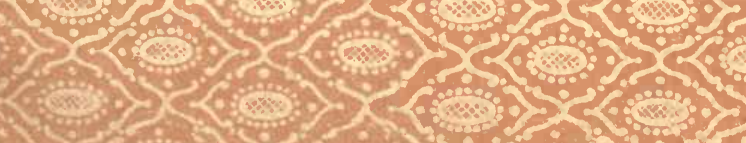







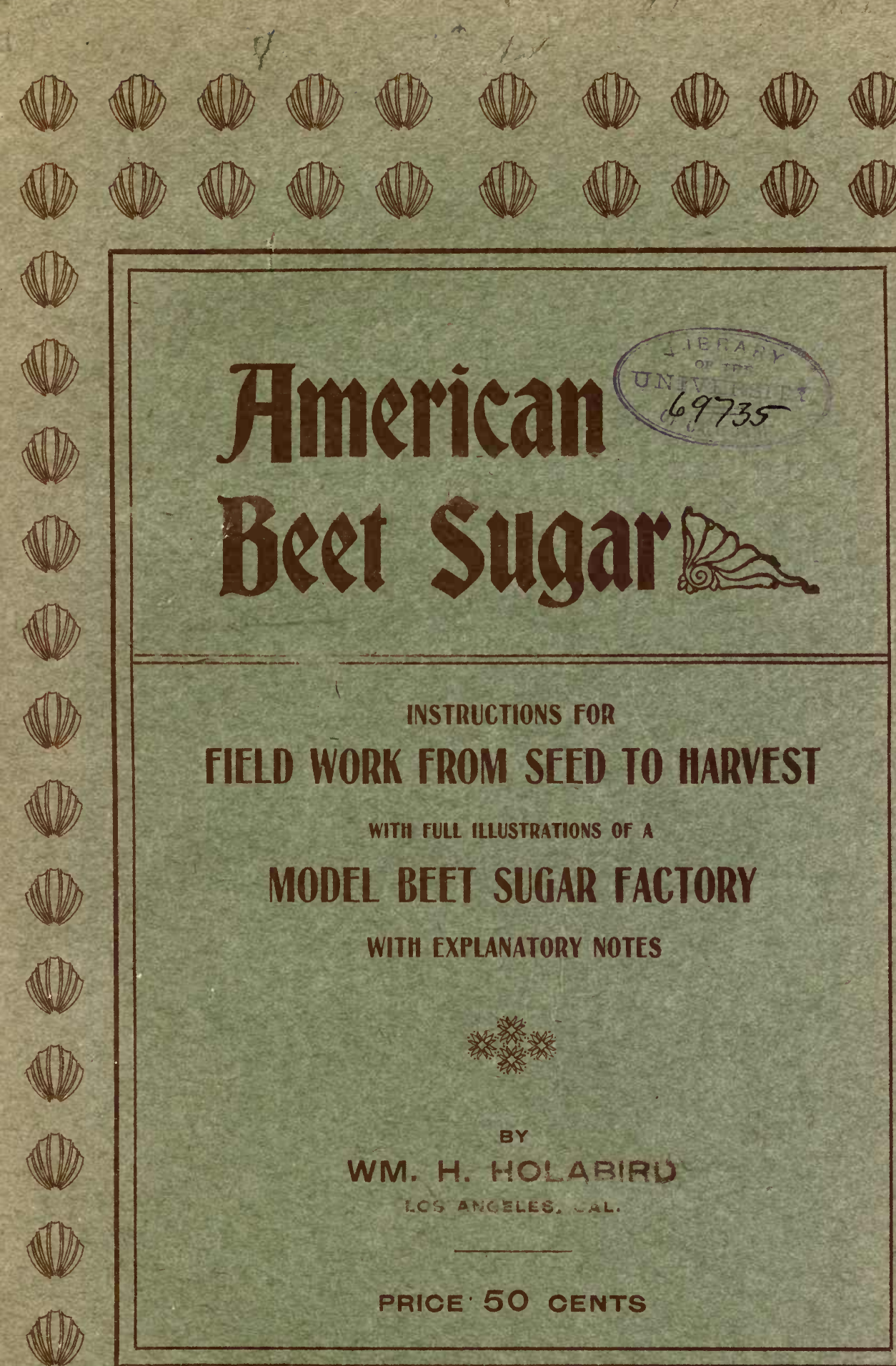

(v)

(1)

(1)

(1)

(1)

(10)

(WD)

(1)

(UD)

(10)

(1)

(WD)

(10)

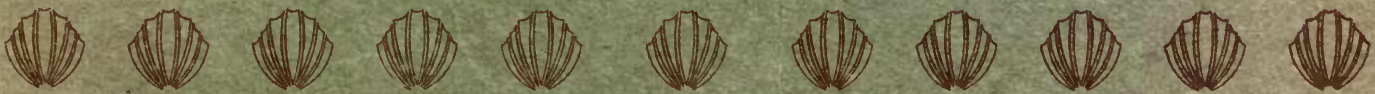

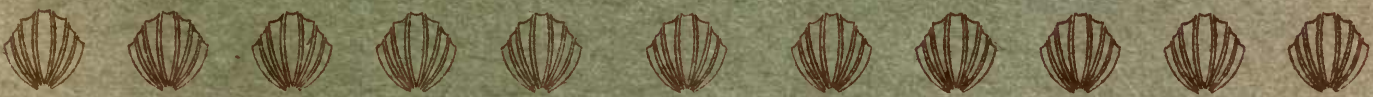


Compliments of ..

W. H. HOLABIRD

308-310 Byrne Building LOS ANGELES, CAL.

UNIVERSIIY

uf CALIFOR: : 
Among the Journals giving most enthusiastic support to the development of the Beet Sugar Industry, and to whom the writer is indebted, are :

THE SUGAR BEET of Philadelphia, Pa.

THE CALIFORNIA SUGAR BEET, San Francisco.

THE LOUISIANA PLANTER, New Orleans.

THE PACIFIC RURAL PRESS, San Francisco.

THE ORANGE JUDD PUBLICATIONS, Herbert Myrick, Editor, Springfield, Mass.

They are worthy of the most liberal patronage by the American people.

The Illustrations show the .......

\section{LOS ALAMITOS SUGAR COMPANY'S BUILDINGS AND MACHINERY}

The photographs were taken while the works were extracting the sugar from 400 tons of beets daily. 

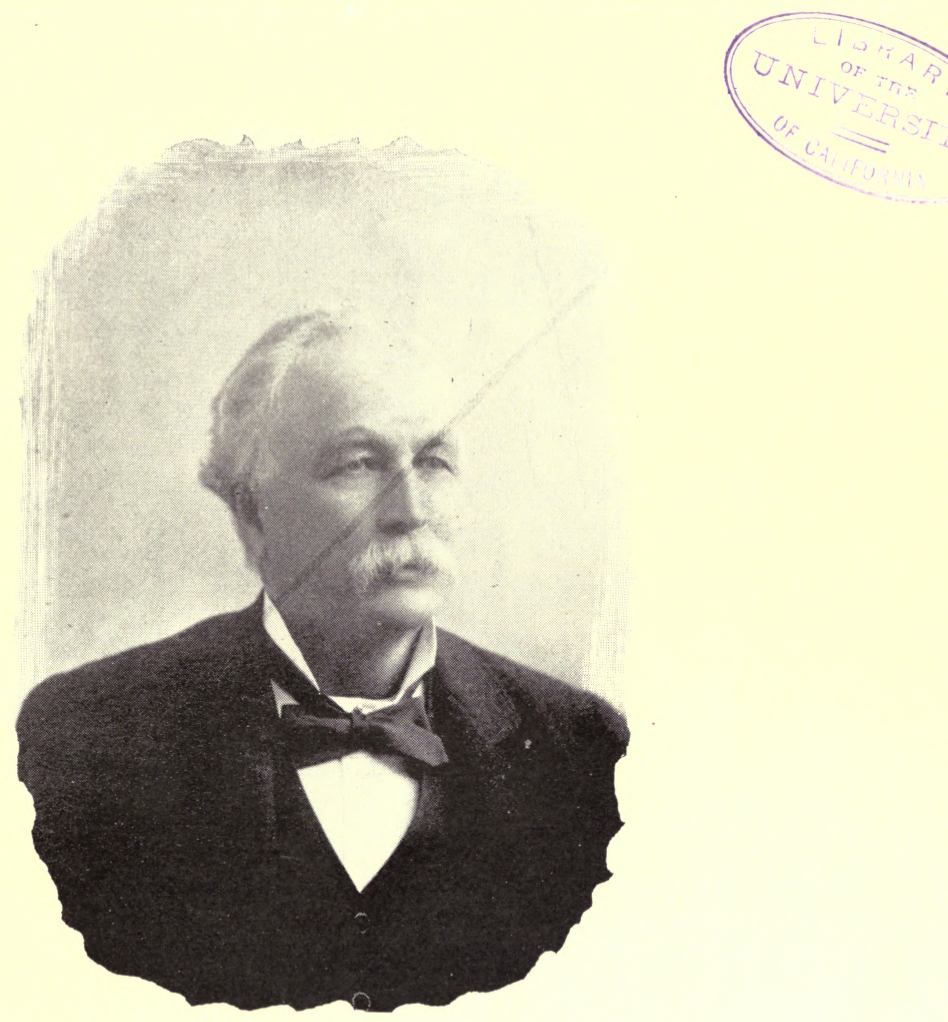

E. H. DYER, ESQ.

The Pioneer Beet Sugar Manufacturer in America.

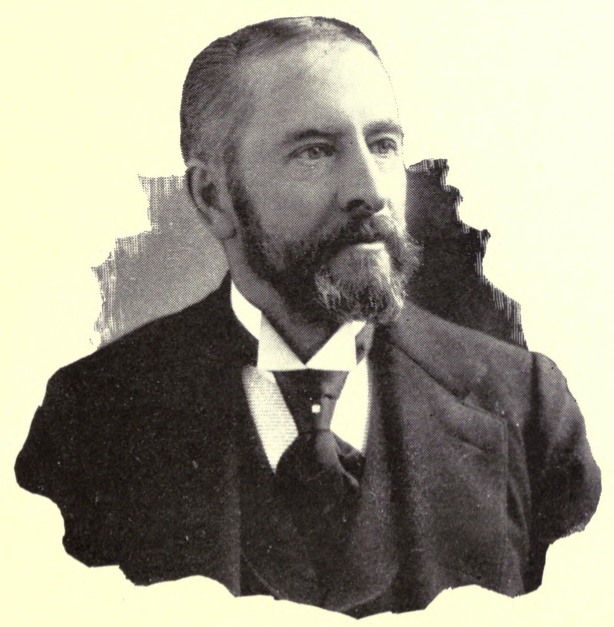

THOMAS R. CUTLER, ESQ.

Promoter and Manager Utah Sugar Co., Lehi. Mr. Cutler backed his judgment with his capital and won. 


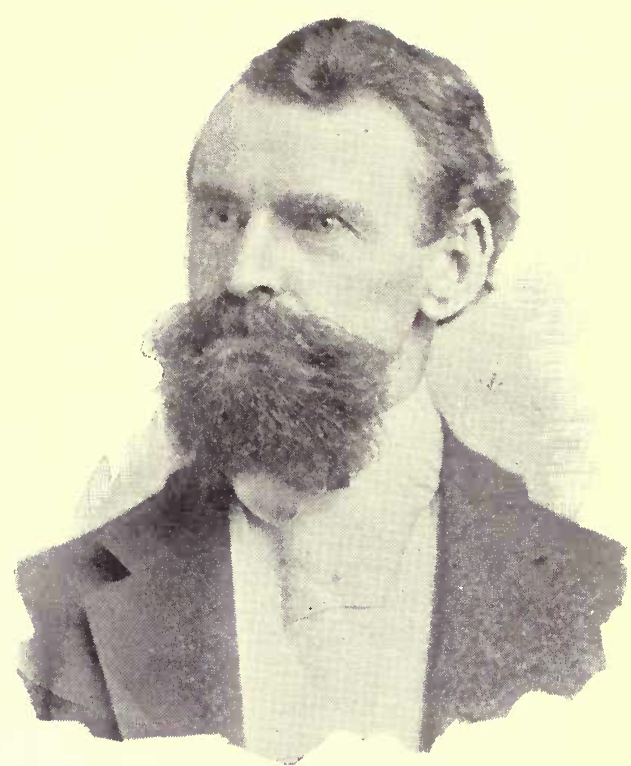

WILLIAM A. CLARK, ESQ.

PRESIDEN'T LOS ALAMITOS BEET SUGAR CO.

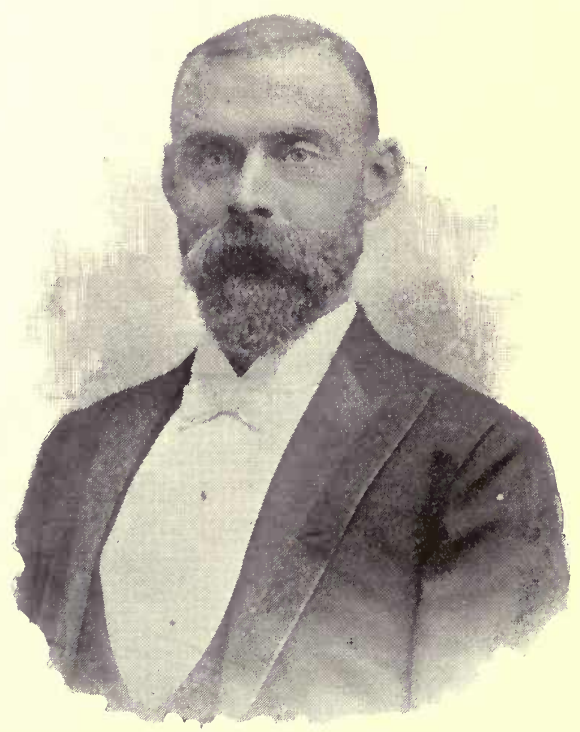

J. ROSS CLARK, ESQ.

VICF-PRFSIDENT AND MANAGER LOS ALAMITOS BEFT SUGAR CO.

In the face of possible adverse legislation, with the unjust Hawaiian treaty in full force, Messrs. Clark invested one million dollars in their beet sugar house and lands adjacent. The results have shown the wisdom of their mature judgment. 


\section{AMERICAN BEET SUGAR}

INSTRUCTIONS FOR

FIELD WORK FROM SEED TO HARVEST * * $*$ WITH FULL ILLUSTRATIONS OF A MODEL BEET SUGAR

FACTORY * * WITH EXPLANATORY NOTES * * * *

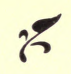

BY

WM. H. HOLABIRD

Los Angeles, California

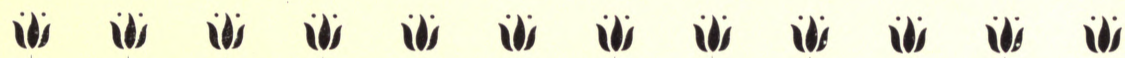

ids ids ids ids ids ids ids ids ids ids ids ids ids 

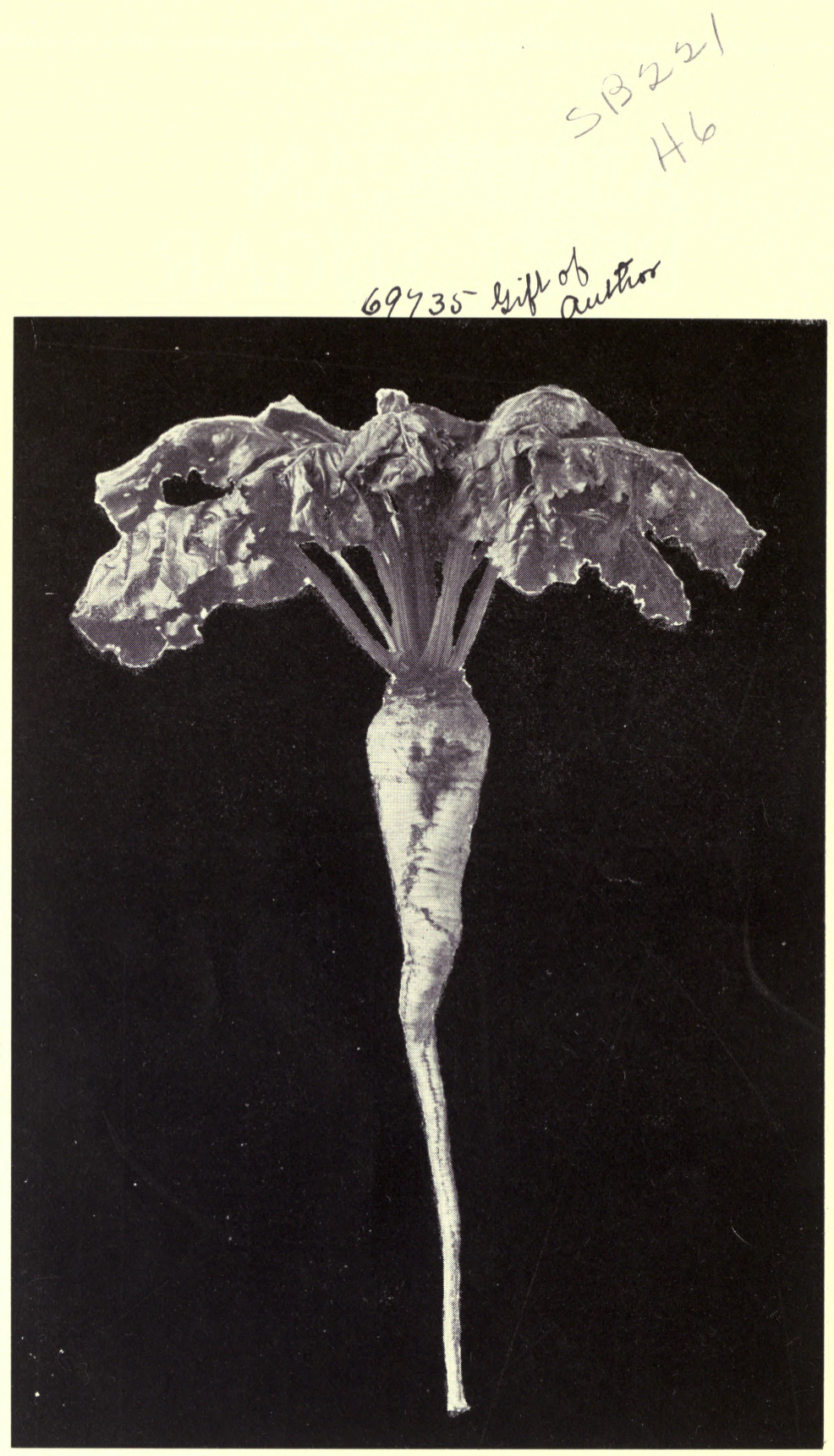

AN IDEAL TYPE OF SUGAR BFET.

From "Pacific Rura! Press". 


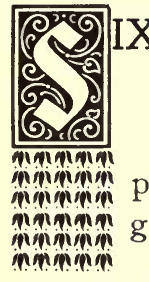

\section{MILLIONS OF HEADS OF AMERICAN FAMILIES

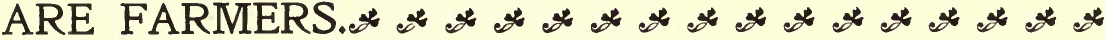

Thirty millions of people and upwards constitute the agricultural population. Their prosperity or their adversity affects the nation to a greater degree than any other class.

Seventy-four per cent of our total exports are agricultural products, chiefly staples sold at so small a margin of profit as to make it a question whether it would not be wiser to abandon their production in excess of local needs. No new crop can be suggested that will so thoroughly change these unfortunate conditions as the Sugar Beet. Consequently in the development of the Beet Sugar industry lies the hope of American agriculture.

No other nation in the world is increasing in wealth and intelligent population in comparison to the United States of America.

In no other country is the burden of taxation lighter, or the guarantee of safety to capital invested greater.

In no other country has inventive genius been given greater encouragement, or reaped greater results.

Particularly in the manufacture of beet sugar machinery has this fact been illustrated, as is shown in the very successful sugar factories at Alvarado, California ; Lehi, Utah; and Los Alamitos, California, the first, the parent beet sugar factory in the United States; the last, the best possible type of what American genius and American-made machinery can accomplish.

The subject is of vast importance, dealing with an industry the development of which interests millions of people and capital of colossal proportions.

EFFECT CN COMMUNiTy LIFE. - The effect on community life of the establishment of the beet sugar industry, with necessary capital, amidst favorable physical conditions, is very striking.

The results are best shown at Watsonville, Cal., Chino, Cal., Los Alamitos, Cal., and Lehi, Utah, particularly in the three last named places. Chino has grown from a mere hamlet in the midst of a stock farm to a town of no small importance. Over two hundred and fifty thousand dollars per annum are paid to the beet growers, in addition to a sum nearly as large for labor and officers' salaries connected with the factory. Lehi, Utah, was a very ordinary settlement; its picturesque surroundings and fertile soil did not make a market for the farmers' products, and up to the date of the establishment of the sugar factory there was little more than a bare living for the farmer; he had no bank account, his taxes were not always paid promptly, he owned no comfortable carriage or pleasure vehicle, his lines were hard and unpromising (as is too true in the case of all outlying farming villages, no matter where they are situated). But the sugar factory came. A cash market, at a fixed price, was given him for his beets. Seven years have passed. A bank with 700 depositors exists, largely farmers, and when the writer visited this most interesting community, the balance to the credit of the depositors exceeded $\$ 70,000$, although it was the end of the season and just before marketing the beets, hence the time of all times when the cash on hand should be the least amount. The banker said, "We have no delinquent taxes, the farmers 


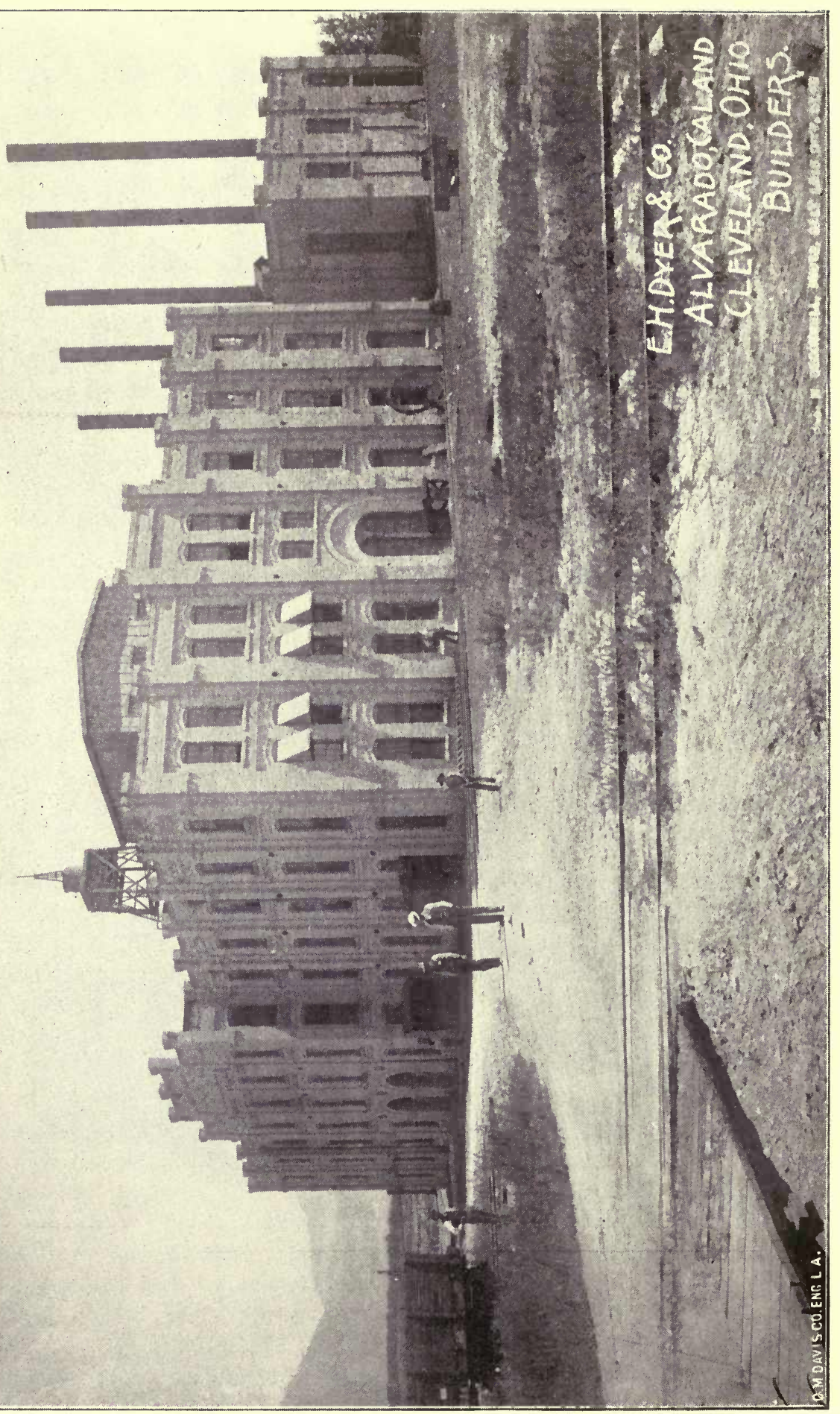

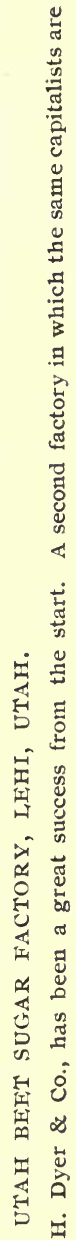

轨

อิ

:

范

몀

突品

吾这

T.

कृ.

क

뭉

这

先 
are not in debt as a class ; they all, or nearly all, own comfortable carriages ; their homes, though simple, are comfortable: pianos and other luxuries are not uncommon. Farm values are high now, whereas in the days before the factory came, they were very low. The quality of other crops with which they alternate their beets is much improved and the quantity is greater." An air of thrift pervaded the entire community. New homes were being built and public improvements made, and Lehi, Utah, stands to-day as a living illustration of the results of a good market for a rich farm product, to first hands, with no middle man between.

That the capitalists who invested in Lehi are at least satisfied, that they made no mistake in investing $\$ 35^{\circ}, 000$ to $\$ 500,000$, is shown by the fact that they are organizing other sugar factories in the State of Utah, as well as in adjoining territory. Capital so invested reaps a handscme profit, which is proper and right.

Los Alamitos, California, is the youngest town or community dependent upon a sugar factory.

Ground was broken in the fall of ' 96 . The situation was a great unsettled valley, the nearest railroad station seven miles away. The soil, virgin and of surprising fertility, had been of little use save to produce a coarse grass for pasture. One year has passed, and a transformation has taken place that is most interesting to note. The Southern Pacific Company extended their line to the site now christened "Los Alamitos." A town of 500 people came into existence as if by magic. Water-works, hotels, stores, livery stables and comfortable homes were built in less than six months. Thirty-five hundred acres of land were broken up and put into beets, the area to be doubled in 1898 .

Conspicuous in the foreground, the magnet that drew the people, the mint that turned beets into dollars, stands the splendid Los Alamitos Beet Sugar Factory'; without which the valley would be still a pasture, unattractive and uninhabited by human beings.

AN IMPORTANT QUESTION in the development of this magnificent industry is, shall our factories be built by foreign workmen, or shall we encourage the American engineer, and only rely upon American genius to create and install these great hives of industry?

To prove that Americans are fully competent to do this, we have only to cite the primary and wonderful success of E. H. Dyer \& Co. in the Alameda Sugar House at Alvarado, California,-works that were originally of foreign make and under foreign technical management, and as such incompetent.

It was then that E. H. Dyer, who still had confidence in the business, believing that with good management it could be made profitable and successful, having purchased the land and buildings owned by the old company at Alvarado, undertook the difficult task of interesting capital, but in the face of so many failures, and at a time when mining and other enterprises offered such inducements, it was not until February, I879, that the Standard Sugar Company was organized, with a capital stock of $\$ 200,000$. This company made a success from the start. The profit of the first four campaigns was \$IO4,000, this being the first beet sugar made in the United States at a profit.

About this time Claus Spreckels and the Sugar Trust were cutting prices, and Mr: Dyer saw that in order to continue the successful manufacture of beet sugar in this country it would be necessary to erect a larger and more economical plant. 


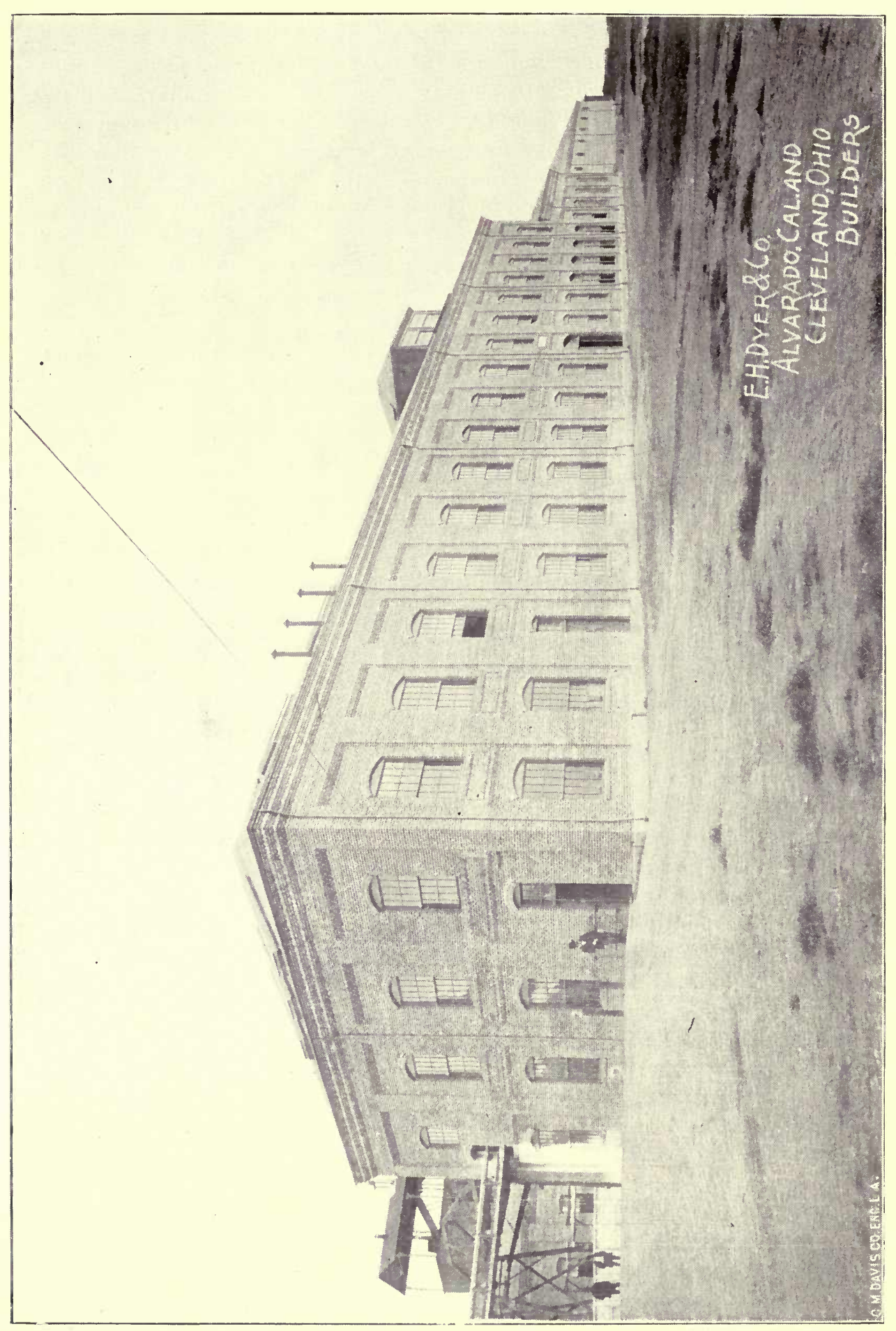

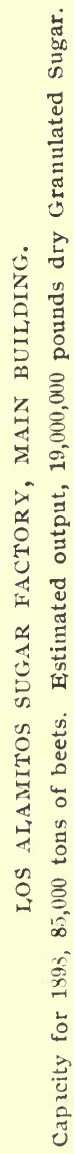


With this object in view, he, with his son, Edward F. Dyer, and nephew, Harold P. Dyer, spent several months in France and Germany, visiting the largest sugar factories and works for the manufacture of beet-sugar machinery there.

Upon their return to this country they designed and erected the factory at Alvarado, in accordance with American ideas and with special reference to the economy of labor and fuel, which enabled them to extract all the available sugar from the beet at a much less cost than ever before. These years of experience convinced Mr. Dyer that the business could be made a grand success in the United States.

This was in 1879 , and the factory is still in operation; the capacity was increased to 300 tons per day in I888, and has been increased for the I897 crop to 800 tons per day. The success of the Alvarado factory led Mr. Spreckels to build the Watsonville factory in $\mathbf{1 8 8 8}$, and also the Oxnards, the Grand Island (Neb.) factory in 1890 . Since that time the Oxnards have built their Norfolk (Neb.) and Chino (Cal.) factories.

In a recent book published in the interests of sugar, a gentleman well known as an organizer and promoter of beet sugar industries is credited as being the "founder of America's beet sugar industry." This is erroneous, and if credit is to be given at all, let it be given where it belongs. To E. H. Dyer of Alvarado, California, all the credit of founding the industry that promises to represent more capital and occupy more people than any enterprise in the United States belongs.

The remarkable success at Alvarado led E. H. Dyer \& Co. to arrange for the construction of the machinery for other factories; consequently an alliance was made with the most elaborate machine shop in Cleveland, Ohio, where was built in I89I the first complete American beet sugar works, which was erected in the beautiful Utah valley at Lehi. This plant was not only of American make but was technically managed by the builders for two consecutive years; this factory, incorporated as the "Utah Sugar Company," made a dry granulated sugar of superior quality, which found a ready market; the company always making money and the community constituting the village of Lehi prospering beyond the comprehension of anyone not conversant with the results of the establishment of such an industry in an agricultural community.

In I896 Mr. J. Ross Clark of Clark Brothers, bankers and smelters of Butte, Montana, sought health in the genial climate of Los Angeles. Finding what he sought for, he cast about for lucrative investment of idle capital. The beet sugar industry was not at that time as prominent before the people as it is to-day, although the dividends had been large and regular by the three plants in California and one in Utah. Fortunately Mr. Clark met Mr. E. F. Dyer, and becoming interested in the possibility and ultimate expansion of the beet sugar business, made most careful inquiry, visited the Lehi and other beet sugar factories, confirming every assertion made by Mr. Dyer, with the following results:-

In I $897 \mathrm{~J}$. Ross Clark and his brotber Wm. A. Clark (a multi-millionaire) organized "'The Los Alamitos Sugar Company," located the plant twenty miles from Los Angeles, Cal., gave E. H. Dyer \& Co. a contract to erect a 350-ton plant and have it ready for the crop of the same year,- ' 97 . The mill was completed on time, perfect in every detail. The first campaign was a phenomenal success, and resulted in an enlargement of the factory to double its original capacity for the crop of 1898 . The investment of the Clarks in the Los Alamitos plant was increased by the purchase of 8000 adjoining acres the following season, with the in- 


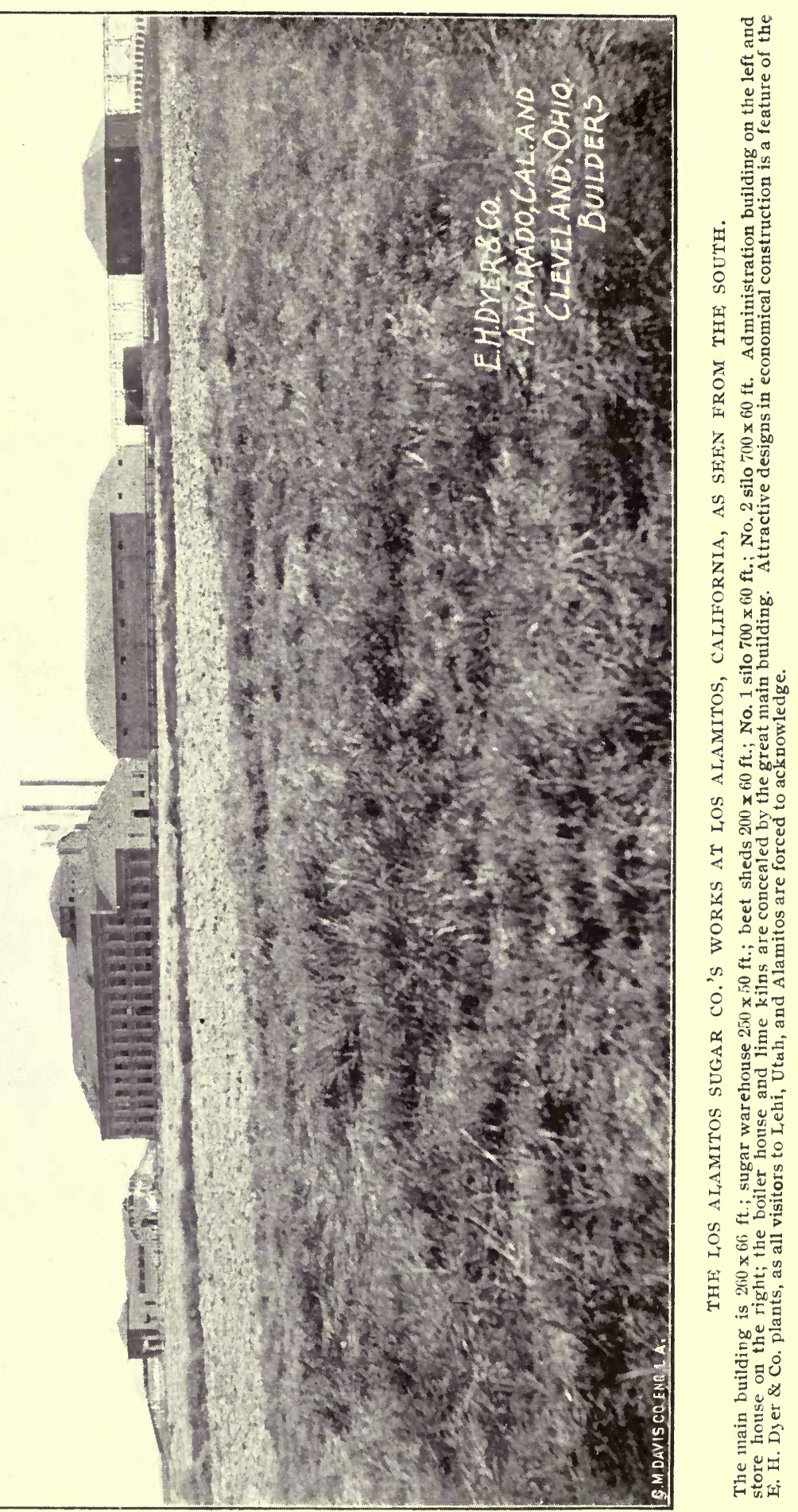


tention of erecting in '99 a second sugar factory, making their total investment $\$ 1,325,000$.

When it is considered that Messrs. Clark are of the most conservative type, successful in all their business ventures, possessors of unlimited capital, the attractions which the beet sugar industry offered must have been more than ordinary.

The following letters confirm all that has been affirmed by the writer:-

$$
\text { [COPY.] }
$$

LEHI, UTAH, September 9, I895.

DEAR SIR: In answer to your inquiry, we beg to say that we made an extensive tour in Europe last year, visiting quite a number of the largest beet sugar factories in Germany, Belgium, and France. Of course we picked up quite a number of ideas, but came to the conclusion that our factory was as compact as any we saw. The arrangements of the machinery in many factories in Europe being of the nature that there is no regard for economy of labor. We will say that our factory is satisfactory to us; the machinery being placed in such a form as to very much economize the labor question.

Our factory was built by E. H. Dyer \& Co., with guaranted capacity of 300 tons of beets for each twenty-four hours. We will say that we have demonstrated already that they gave us everything that was contracted for.

Last season we ran as high as 4 I I tons through in one day, and the average for the entire season was 335 tons per day. We are hoping and expecting that we shall exceed that average this season.

We have also been quite fortunate, since we commenced five years ago, in having no serious breakages that entailed any loss of time.

We are perfectly satisfied that with beets that will give us the average polarization of I6 per cent, that we can make granulated white sugar at less than three cents per pound. We employ an average of ninety men inside the factory, that is, forty five on a shift.

Yours truly,

(Signed) Thonias R. CuTLER, Manager.

\section{[COPY.]}

Mr. Clarence M. Fenton, Secy.,

Los Alamitos, Cal., Sept. 26, I897.

Erie Preserving Co.,

Buffalo, N. Y.

DEAR SIR: Your favor of the 2oth inst., asking for information regarding our factory and its builders, E. H. Dyer \& Co., received. In reply, will say that the factory and its product has been perfectly satisfactory in every particular, the factory having run over its estimated capacity, and the product is pronounced to be by all, the finest sugar in the market. In regard to the factory and its builders, E. H. Dyer \& Co., we have this to say, that the quality, arrangement and efficiency of the machinery seems to be most perfect, enabling us to do the greatest amount of work with the minimum amount of labor and fuel. Situated, as we are, in the beet-growing West, and being near the Chino factory, acknowledged to be of the finest European machinery, we have had unusual opportunities for comparison, and do not hesitate to say that we have the model plant of America.

As to the Dyers, we take pleasure in saying that they have given ample proof that they are thoroughly experienced, capable and honest, and that any contract 


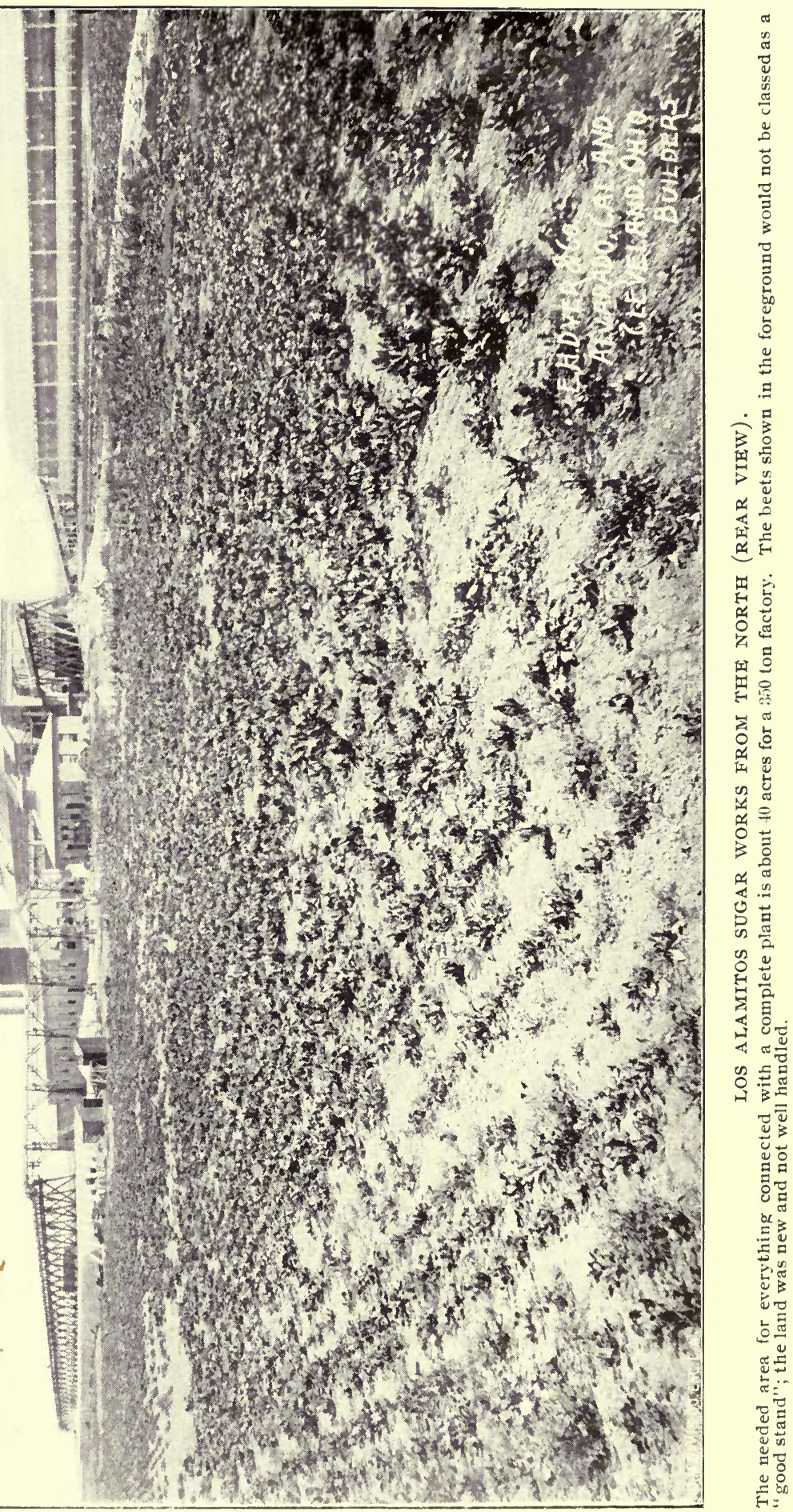


that they undertake will be carried out to their credit, and satisfaction of those employing them.

In this instance, they constructed our plant in every detail from the foundation up, and in addition to this, systemitized the office, laboratory and other clerical work so far as it pertained to the factory ; furnished all the skilled and unskilled employees, and in an exceedingly short period of time had all running as smoothly as an old established business. What is fully as pleasing, it has been a commercial and financial success from the start.

Not over a year ago we were confronted with the same problem as you probably, are today ; whether to embark in the business, or not at all ; if we did, where to get the machinery, and whom to operate it. Today, after having studied the field over and had our experience, we feel that we have made no mistake, and are glad to have an opportunity to testify to the merits of E. H. Dyer \& Co.

Our factory is what the Dyers term their $350^{-}-700$ ton plant ; that is, the buildings, and some of the machinery, are large enough for working 700 tons of beets per day, but only sufficient machinery is erected at first to work 350 tons per day, the balance to be put in whenever desired. This we think an ideal arrangement, while to the uninitiated it would convey the idea of large buildings with much waste room ; such, however, is not the case ; the arrangement of the machinery is such that it requires but little more building than would be required for half that capacity; the advantage is, that the plant may be doubled at a minimum cost at any time, an advantage that every factory that has been built will be glad to avail thamselves of.

We employ about 100 men, all told, 80 of whom work in the factory proper, the balance are engaged in unloading and testing beets, breaking rock, building stock-yards, and other outside employment. We pay laborers from \$1.80 to \$2.00 per day, factory hands $\$ 2.00$.

If you embark in this business, we hope the Dyers will construct your plant; for it will insure the elements of success, experience and ability. The more successful and widely separated factories, the greater our political strength.

There is another point in your letter that I, perhaps, have not touched strongly enough upon, and that is, the comparison between American and foreign machinery. While I do not pose as an expert in machinery, it is apparent to a layman that there is about as much difference between foreign and domestic sugar machinery as there is between an American and a European locomotive, both good in their respective countries, but a foreign locomotive would be of but little use in this country under our conditions.

There are plants now operating in this country, fitted with foreign machinery. They are a constant source of trouble and expense to the owners; they require nearly double the operatives, and 30 to 50 per cent more fuel than either the Lehi or this plant, to run them, which is not a matter of opinion, but facts.

Very truly yours,

Los Alamitos Sugar Co.,

Signed by J. Ross CLARK,

V. P. and Gen. Mgr. 

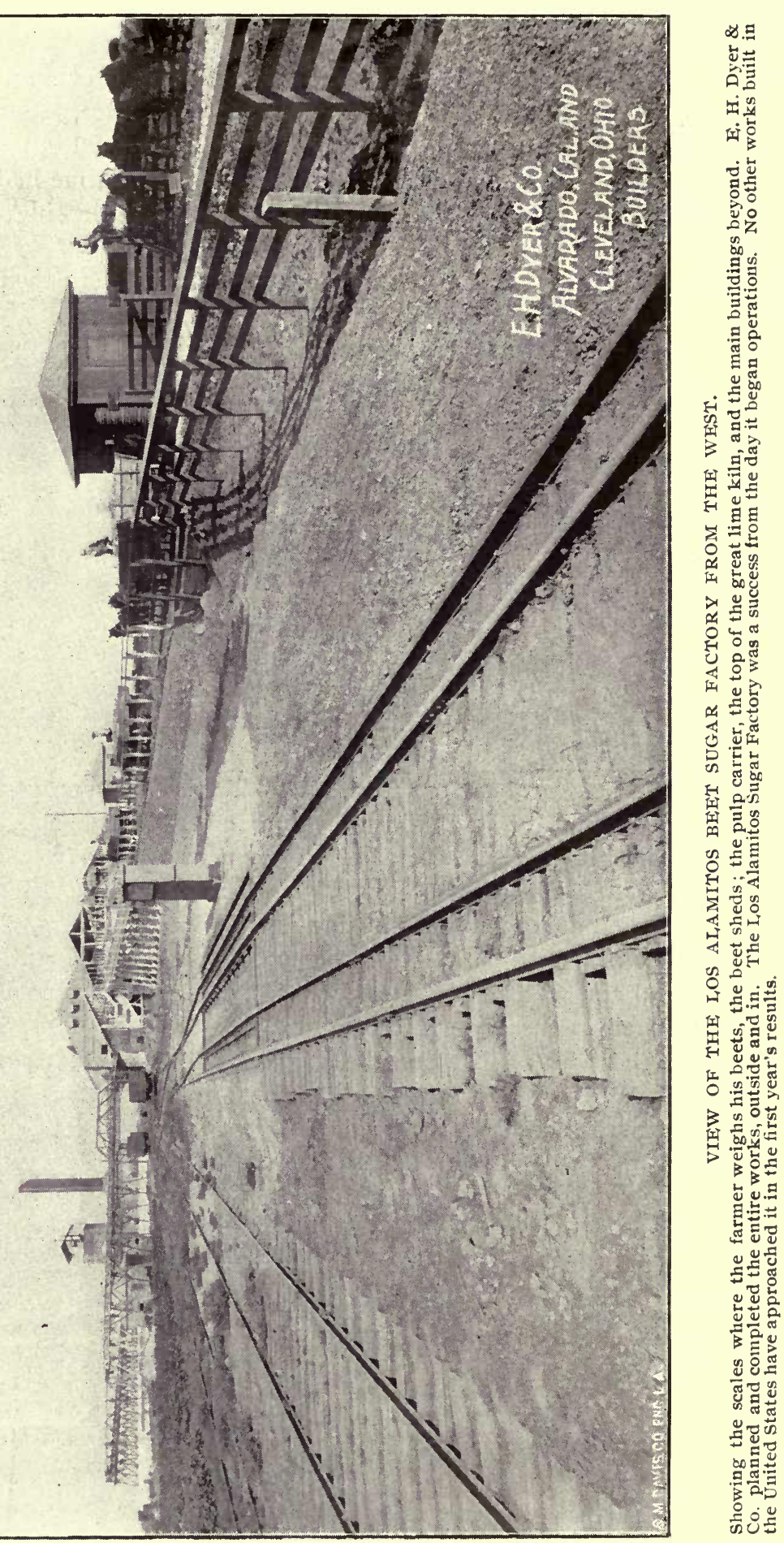
[COPY.]

Fred J. Kiesel \& Co., Wholesale Dealers in Groceries.

Los Alamitos Sugar Co.,

Ogden, Utah, Aug. I3, I897.

\section{Los Alamitos, Cal.}

DEAR SIR: Our first car of sugar came in today, and we desire to congratulate you upon the finest produce that has ever been turned out in California in the beet sugar industry.

We at once mailed out a lot of samples to our most valued customers in order to bring your product before them, and hope it will result in much good, which we trust you will approve of. Will wire our orders direct to you from now on.

Again congratulating you upon the success of this enterprise, we remain, Yours truly,

(Signed, FrED J. KIESEL \& Co. [COPY.]

\section{J. Ross Clark, Manager,}

Boston, Mass., November 2, '97.

\section{Los Alamitos Sugar Co.}

DEAR SIR: Your favor of 26 ult. received, also the sample of granulated sugar.

We most heartily congratulate you upon the quality. Not only is it far better than any sample we have seen of German, Austrian or French granulated, but it is the best sample we have seen produced in this country from beets.

The Revere Sugar Refinery, of Boston, prides itself on making the best granulated made in the United States. They never use raw beet sugar, but use only the high grades of centrifugal sugar. Their granulated always commands I-I $6 \mathrm{c}$. per pound more than other refiners.

We have just placed your sugar beside their fine granulated, and it would be hard to say which is the better of the two. Higher praise we cannot give your sugat. We may send for another sample when this is used up.

\section{Yours truly,}

(Signed,) George F. Hall \& Co.

THE FARMER's SHARE IN THE PROFITS. - The writer copies certain statements, made in writing to him. They speak for themselves. (Localities and names are omitted for obvious reasons.)

DEAR SIR: In answer to your inquiry as to what success I have had as a raiser of sugar beets, I will give you an account of my experiences.

I came here with my family in March, I89I, just four years ago. I was in debt at the time, and we had absolutely nothing to depend on for a living except our own good will to work. I rented 22 acres of beet land, but was unable to do all the work myself on account of want of a good team and implements; I paid $\$ 2.25$ an acre to have some of the plowing done. However, that year saw me clear of all my debts, and I had made a good living and put some funds away for a rainy day, and this after paying one-quarter of the crop for rent. In I892 I rented the same land, but broke up a few acres of new land, so that I actually planted about 25 acres. My crop gave an average tonnage of $I_{5}$ tons to the acre with the sugar per cent running from $\mathrm{I} 4$ per cent to $\mathrm{I} 8$ per cent. I did 


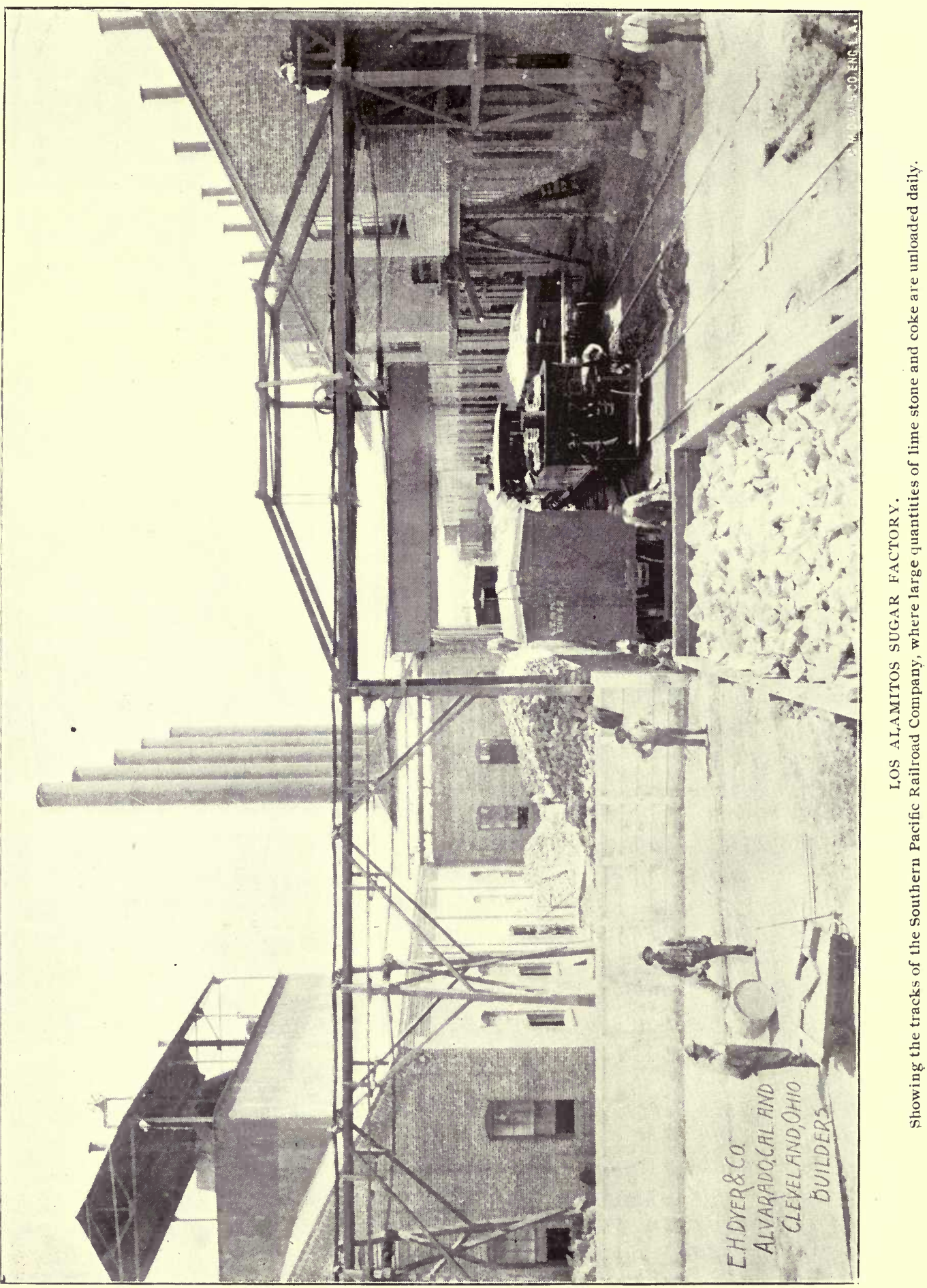


well again this year, so that I was enabled to purchase a good team and wagon, and add to my stock of agricultural implements, and put money by. In I893, being fully equipped with teams and implements, my boys and myself did all the work, and we put in 34 acres of beets, eight of which was new land which I got rent free for the breaking. You can understand that I did well this year, when I say I paid $\$ 754$ rental for the 25 acres. The eight acres of new land gave me ro4 tons, for which I received $\$ 4.00$ per ton. I made this year over $\$ 2,200$, and in October of this year I thought I could commence to buy land, so I paid my first payment down on 60 acres. I continued to have good success, and in 1894 was enabled to make a second payment on the land. I think that this will show what can be done in the beet business. I have now a good home, good teams and good wagons, and all implements necessary to do good farming, and hope soon to own my land. I look upon the beet business as the best payer of good, honest work, and am well satisfied with the results obtained. I have had to work hard before, but have never been paid so well for work done.

(Written in I895.)

Yours truly.

DEAR SIR : It affords me pleasure to give you my experience as a beet-grow ing farmer. I arrived here April I2th, I89I, but did not do much that year, it being too late to go into the beet business. In 1892 , however, I made my first trial, putting in $\mathrm{I} 3$ acres from which I realized altogether \$IOOO. This pleased me so, that the next year, I893, I put in 25 acres. I was not very happy in the selection of my land, as ten acres of this was fruit land which gave but a poor return in beets, though I made good wages; but the other I 5 acres paid me equally as well as in 1892 , and my total returns were over $\$ 1600$. From $53 / 4$ acres I realized $\$ 525$. Last year was a dry year, and we were not supposed to do so well, yet from forty acres my returns were $\$ 2900$, which, after paying all expenses, left me and my two boys $\$ 2300$ for our labor. The average tonnage was $15 \mathrm{r} / 2$ tons to the acre. I have never had less than is tons to the acre, and some have shown 27 tons per acre. My percentage of sugar has been from I4 to I 8 per cent. This country is the best place I have come across yet, either for beet farming or general farming. This last year I had 8 acres of alfalfa ; from this I have fed four horses and four cows, and sold \$I 40 of alfalfa. The average tonnage was $I \frac{I}{2}$ tons per acre each cutting, and I took off five crops. I find plenty of outside work to do, and this amply pays me all my expenses of raising my beet crop. Myself and two boys do nearly all the work; one boy is a little over 12 and the other a little over I4 years of age. I am putting in 45 acres of beets for the coming season, and I know of no crop that pays so well for the work put upon it.

Yours very truly.

Ideal Conditions under which Sugar BeEts can Be Grown SucCESSFULLY. - In dealing with the most important foundation of the industry, we. have, as our standard of excellence, such conditions as will favor the production of the ideal sugar beet. Such a beet will not exceed two pounds in weight. It will be of the parsnip shape, from twenty-five to thirty inches in length from the top of the outstretched leaf to the extreme of the root. It will be free from latteral roots, and when ripe will have few hair-like rootlets, save in the characteristic channel or groove that is always found half winding down the length of the root. In sugar it will average 14 per cent; in coefficient purity, 80 . It will be 


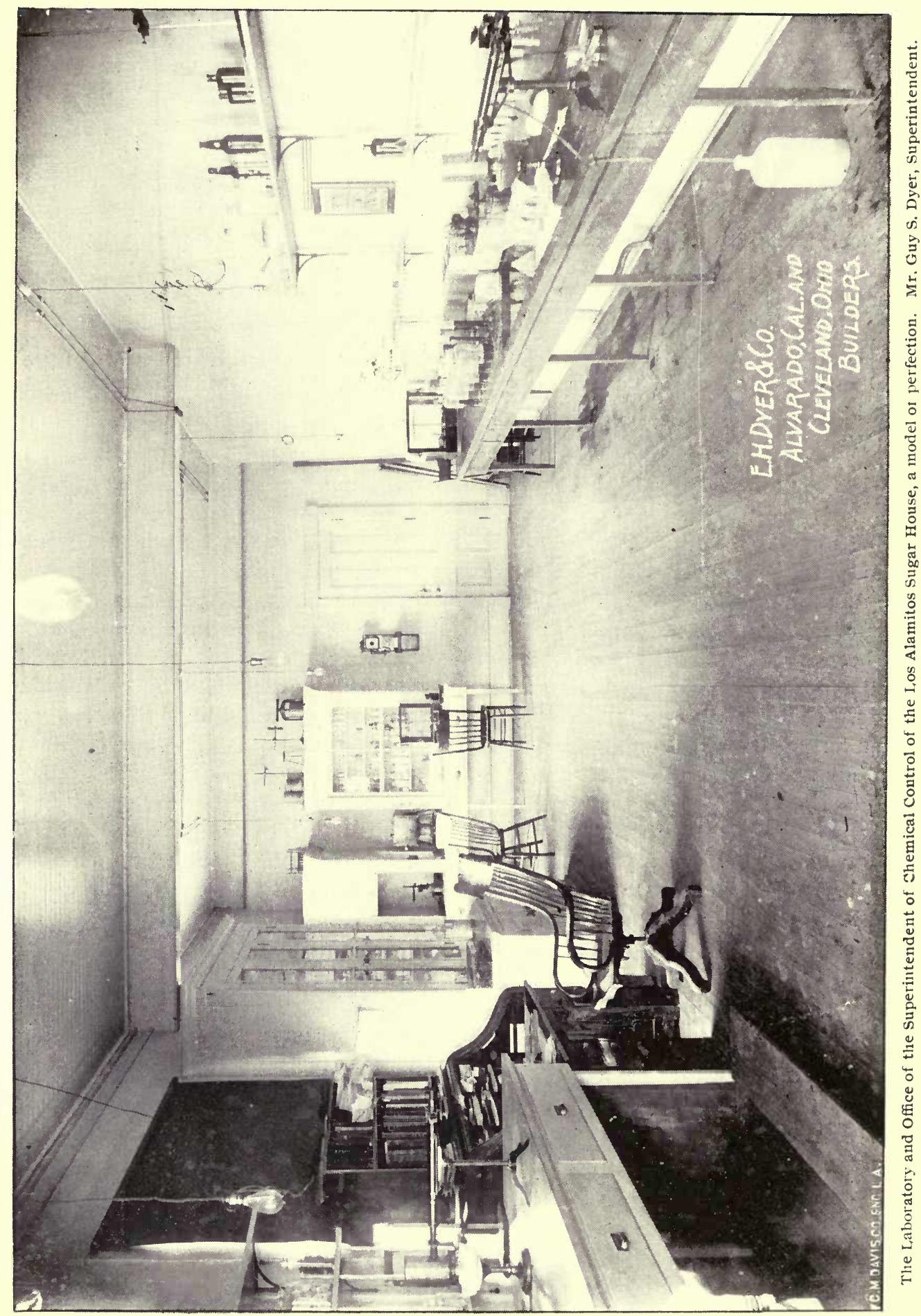


wholly grown beneath the ground. Such a beet root will be very profitable to both the grower and the sugar factory.

LENGTH OF CAMPAIgn.-Experience in Europe and in America has proven that I 20 days is about the limit of "campaign"' (as the factory run is termed) for a season. It is possible, however, to protract this period in California where the peculiar length of seasons permits the first seed to be sown early in February, and the last sowing in June, thus enabling the campaign to begin July Ist and to continue to December Ist; but in latitudes where killing frosts and rain, or both, are liable at any time after October, silos are needed, out of which the beets are taken to supply the factory; hence the danger of attempting a campaign of a longer period. Taking, however, I 20 days as a unit for a 350-ton factory, there would be required 42,000 tons of beet root.

Possible Results.-An ideal soil, with a farmer of peculiar painstaking. should produce sixteen to twenty tons of beets per acre ; but from a large acreage, say 3,000 acres, with 300 different farmers, good, bad and indifferent as they are apt to be, twelve tons is a far safer average to rely upon. Consequently 3,500 acres must actually be planted to beets each year, plus 7,000 acres upon which to rotate other crops in order to maintain tonnage, saccharine and purity; so we have IO, 500 acres as the necesssary area to depend upon for the raw product for a factory of 350 tons capacity.

Quantity of WATER NeEded FOR FACTORy. - If the presence of suitable water (at least a flow of I,500,000 gallons daily), proper drainage facilities easily provided for, limestone of the desired quality reasonably near, and adequate transportation facilities, can all be had, then locate the factory as near the center of the ro, 500 acres as is possible.

DELIVERY BY WAgON Versus RAILROAD.-The location of the very successful sugar factory at Lehi, Utah, and the larger plant at Chino, California, and the smaller works at Eddy, New Mexico, all demonstrate the fact, that whilst it is better for the farmer growing the beets to be sufficiently near the factory to deliver the crop by wagon and thus save paying railway freight, it is possible to secure farmers' contracts for factory delivery by rail to the maximum distance of roo miles. The Chino factory buy fully one-half their product an average distance of 70 miles away ; Eddy, New Mexico, from 50 to 70 miles; Lehi, 25 to 50 miles. The Nebraska factories, the great sugar works at Watsonville, Cal., also buy great quantities that are delivered by rail. Hence, while it is greatly to be desired that the beets be grown near the factory, for the farmers' sake, it is not at all impractical to depend upon outlying lands on the railway.

The Importance of Lime in The Soll.-Prof. Hilgard, of Berkeley, Cal., who is considered the highest authority in America in agricultural chemistry, confirms the experience of all close observers when he states that of all soil ingredients favorable to best development of the sugar-making qualities, lime stands foremost. Another authority, who has had much experience in soil analysis in the West, being agricultural chemist for the Pecos Companies in New Mexico, says :

I. "The beet requires for its development a certain amount of heat, which can 


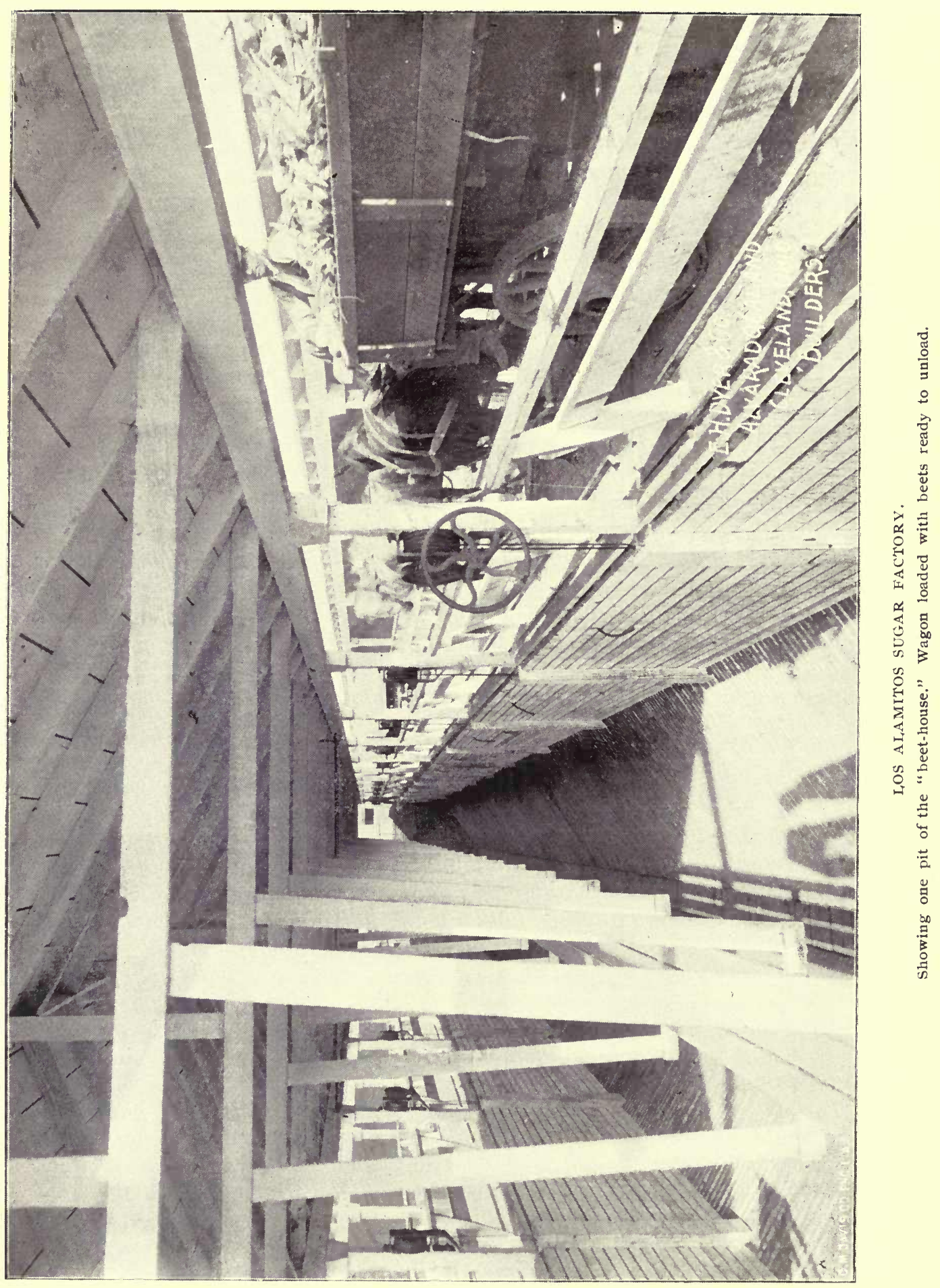


be found by adding up the mean temperature of each day from the date of sowing to that of maturity. Normal heat for the beet is about 3,ooo degrees C., and this is spread over about six months.

$*_{2}$. For every Ioo degrees heat the beet requires so much moisture :

For first period of two months 0.6 inches For second period of two months........................................................... 4 inches For third period of two months. 0.4 inches

And it is very important that these proportions of moisture to heat are in the above order.

The above gives a total for normal heat of $12 \mathrm{x} / 2$-acre inches for the crop.

NoTE-Accordingly an extra amount of moisture in soil when air is dry would be beneficial.

3. Beet seed to sprout requires about i $20 \mathrm{C}$. units of heat, and soil must contain from 7 to $I 7$ per cent. moisture at depth of seed. It will sprout at a temperature little above freezing to 35 degrees C. (94 degrees F.) Best temperature is 20 degrees C. (7o degrees F.)

4. As for soil composition:

a. Phosphoric acid is absolutely needed in sufficient quantity, and more increases sugar.

b. Magnesia appears next important to phosphoric acid.

c. Lime next, and great quantities, and even up to 50 per cent is not hurtful.

d. Potash is needed, but soda can replace most of the potash, and it is said with great advantage as regards purity.

e. Nitrogen. Little is required, and much is decidedly hurtful to sugar production."

* [Dealing solely with beets grown by irrigation. ED.]

Clay SoIl NOT Desirable.-Clay soils without an admixture of loams are nhjectionable, being hard to pulverize into a perfect seed-bed, unless taken at just the right moment, and more difficult to keep loose and in high tilth, and still more annoying in harvesting, owing to the tendency of the beet root to break off in the tenacious soil, and also the persistency with which the clay sticks to the root in such large quantities as to cause excessive tare at the factory. Loose, friable soils, such as are classed as No. I corn or wheat land, ordinarily can be classed as beet land; but beware of what is commonly known as "hard pan," unless at a depth of seven to ten feet from the surface. Level lands are far more desirable than hills for obvious reasons. It is always safest to have proposed factory sites examined carefully by an expert, both as to soil for beet growing and other important conditions.

THE SEED.- This is one of the important topics. Given scientifically produced seed, good land, a fair climate, a good farmer and favorable conditions, and the results will be perfectly satisfactory; but given seed of unknown pedigree, produced in the same unscientific way most of our agricultural seeds are produced, with all the conditions named in the first instance perfect, and your factory will suffer as well as the farmer. This has been illustrated in many instances, and proven absolutely true; not to the extent of causing a factory to fail, but the rejection of beets by the factory because of low sugar content and still lower purity, to the total loss 


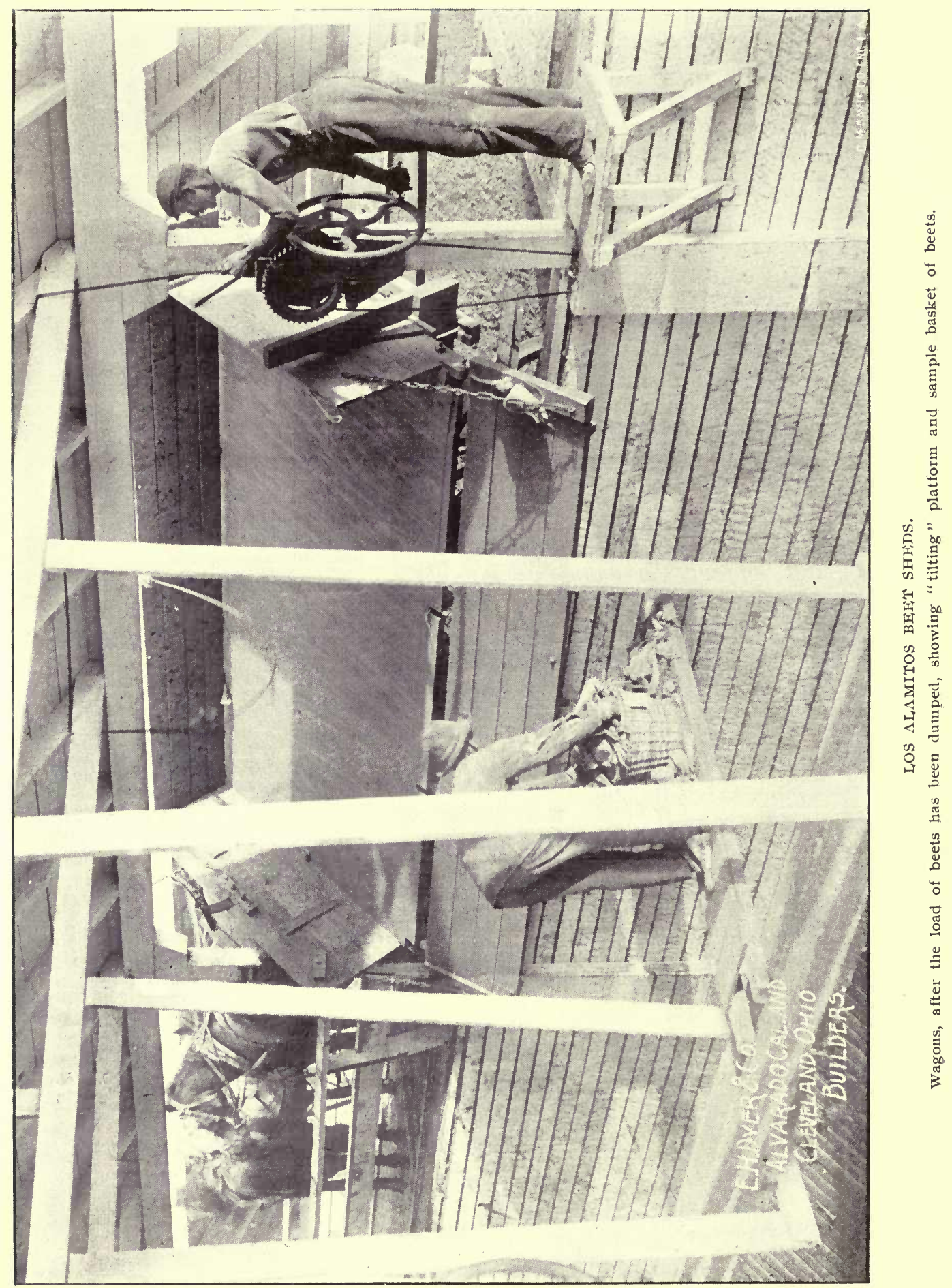


of the farmer; all because he tried to save a paltry two or three cents per pound on his seed by buying from a general seedsman rather than paying the factory for the scientifically produced seed. In fact, most factories stipulate that they will only receive beets grown from seed furnished by them. The method of production of sugar beet seed is of absorbing interest. It is a good illustration of the survival of the fittest from a scientific test. The two varieties which have been most widely grown in this country are the "Vilmorin Amelioree" and the "Klein Wanzlebener." The certainty that the seed has been grown according to the most scientific methods is of greater importance to the beet grower than the variety. The beet has reached such a high state of perfection as to make the least degree of laxity in its treatment exceedingly dangerous to its qualities.

The sugar beet of to-day is the most aristocratic vegetable on earth. From the most humble origin, the "Beta Vulgaris," through the most careful and scientific selection of the mother beets, has become the highest type of food plants known to man. The extreme care exercised in the production of sugar beet seed in Europe is briefly described as follows :

How BeEt SEED IS Grown IN EUROPE.-Assuming for the start seed of the highest attainable quality. This is planted in the spring in the usual manner and the crop cared for in all respects as a good beet farmer would handle a crop for the factory. In the fall, at the time of harvest, the beets are carefully examined as to their physical characteristics of form, color, size, shape, condition of leaves, and method of growth. Those coming up to a standard previously fixed upon are reserved for seed, whilst all others go to the factory. This selection usually reserves from one-sixth to one-eighth of the crop as mother beets for the next season. In the early spring of the second year, these mother beets are taken from the silo and subjected to a chemical analysis, for the purpose of securing, for planting, only those of high sugar content and purity.

The analytical process, in brief, consists in taking a small sample from each individual beet in such a manner as fairly to represent the whole beet,- - this does not in any way injure the root for planting. The juice is then expressed from the sample and polarized. In this way, all of the beets reserved the previous fall are divided into three classes, viz: first, those that fall below a certain minimum per cent. of sugar, say I 6 per cent. go to the feed stable; second, those that in sugar content run between 16 per cent. and 18 per cent. will be planted as seedproducing or mother beets ; third, those that run above 18 per cent. in sugar will be planted for seed to keep up the stock.

For convenience, we will call these classes I, II and III, and confine our attention to class II. When this chemical selection has finally been made. the beets in class II are planted. In the autumn the seed stalks are cut, the seed thrashed out, cleaned, and put away for the winter. In the following spring - the third from the start - this seed is planted, but in a manner a little different from the ordinary, inasmuch as the rows are closer together and the beets are thinned to a distance of from three to four inches, the object being to produce a very small and rich beet. The usual summer care is given, and in the autumn these very small beets are harvested; another selection on the basis of their physical characteristics made, and those retained are carefully stored for the winter. In the spring of the fourth year these small and very rich beets are planted for seed production. Ac- 


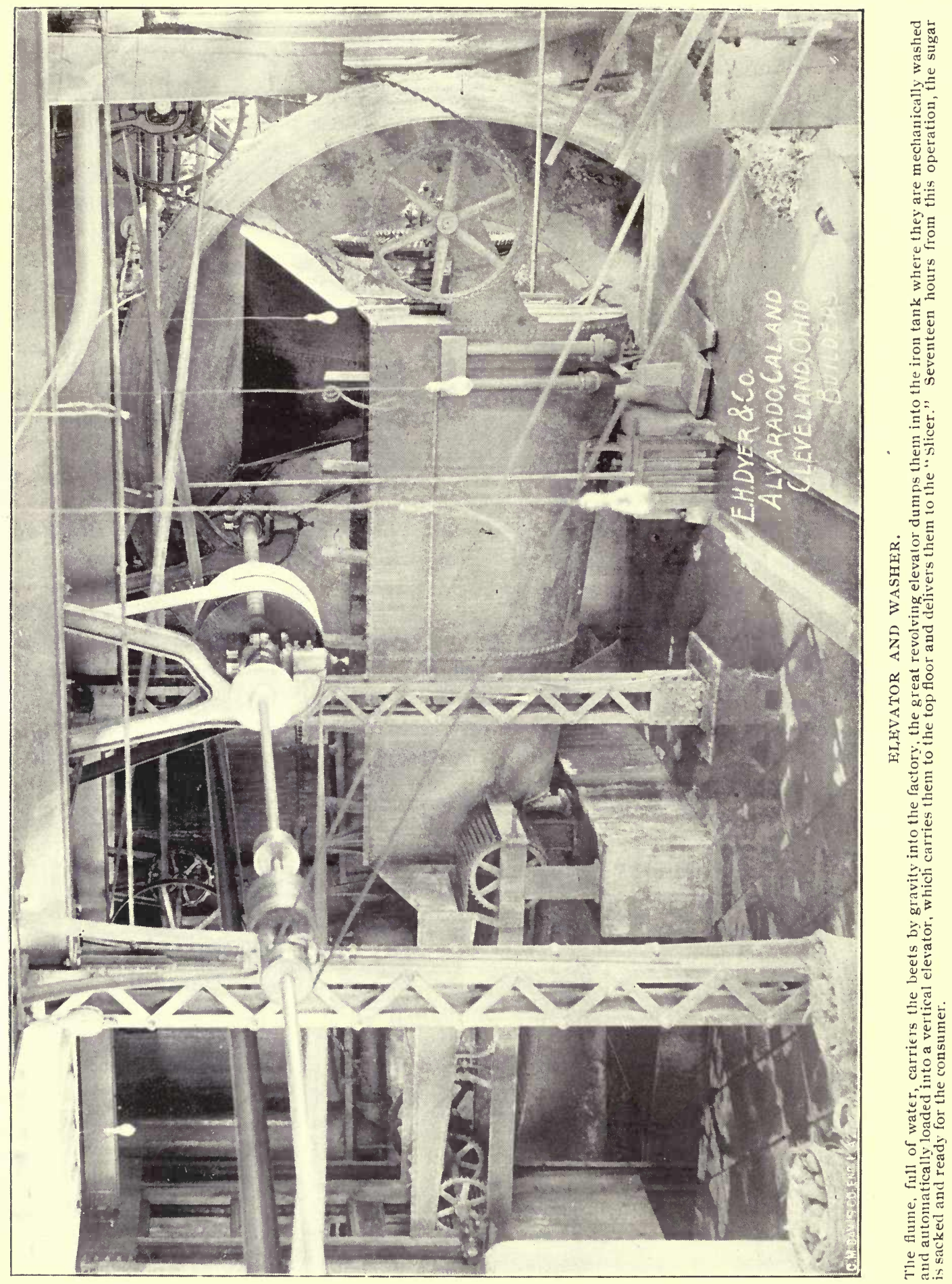


cording to this method, seed to be offered for sale comes on the market in time to be planted during the fifth year after the first steps in its production were taken. This plan, or one similar, is adopted by all successful seed-growing specialists in the old country. Of course, after the first lot is ready for market, each succeeding season furnishes a crop. The only long delay comes in starting.

Average PER CenT. OF Sugar in THE BeET. - The writer has assumed that I4 per cent. with 80 purity is nearer the average than higher percentages or purity. It must be admitted that for days the factory average at Los Alamitos, Alvarado, and Pecos Valley has ranged from $\mathrm{I} 7$ to $\mathrm{I} 8.50$ per cent, with a purity from 80 to 84 , but it would be unwise to hold out the inducement to the country at large that such results could be depended upon. Poor land, poor stands, and poor farming will always prevent high averages, hence the selection of 14 per cent. as the safe unit of sugar in the beet to be calculated upon.

IRRIGATION.- Sugar beets, like most agricultural products of the temperate zone, can be successfully grown by irrigation, as is well illustrated in Lehi, Utah, and Pecos Valley, New Mexico. The chief danger lies in the too frequent use of water and the consequent neglect in cultivation. Particularly when approaching maturity should the water be kept away from the beets. An otherwise successful farmer in the Pecos Valley who had been accustomed to growing potatoes and cabbage by irrigation, and had been successful in Colorado, attempted to apply the same rules to beet culture, and made an unsatisfactory showing. The Mormons in Utah have made greater success, and there can be no risk whatever in establishing a sugar factory solely dependent upon an irrigated product. The larger area devoted to beet culture, however, will be where the submoisture or natural rainfall during the period of growth is sufficient to make a crop without irrigation. Beets will not thrive if neglected. Sugar and weeds, or sugar and neglect in any way, are not found in the same beet patch.

DEEP PIOWING.-Deep plowing on old land is of highest importance; fall plowing is preferred, and if farmers could only see the great benefit resulting from subsoiling, it would be more generally practised. Otherwise the surface plow must go down 8 to 12 inches. When planting time comes, the land must be perfectly pulverized. This may be by one harrowing, or it may require six. Seed will not germinate well in rough ground, the rows will not be straight and the stand will be uneven, some seed being too deeply covered and others not covered at all. Deep plowing and perfect pulverization precede the seeding.

QUANTITY OF SEED NEEDED. - The quantity of seed required per acre ranges from $12 \mathrm{I} / 2$ pounds to 20 . In some soils the seed germinates more quickly than in others; the temperature may be too high or too low. Many things militate against the germination of every seed, so it is best to plant enough to insure a good stand, and also to exercise the force necessary to lift the crust and let the tender germs out. The rows should be 8 inches apart, which permits room for the horse to walk in cultivation and the leaves perfectly to shade the ground. The proper depth for planting aepends upon the locality. In moist land with a humid atmosphere, $I / 2$ to $I$ inch is fully deep enough, while $I \frac{1}{2}$ inches in very arid regions is necessary, owing to rapid evaporation of surface moisture. Where conditions are perfect, shallow planting is best. 


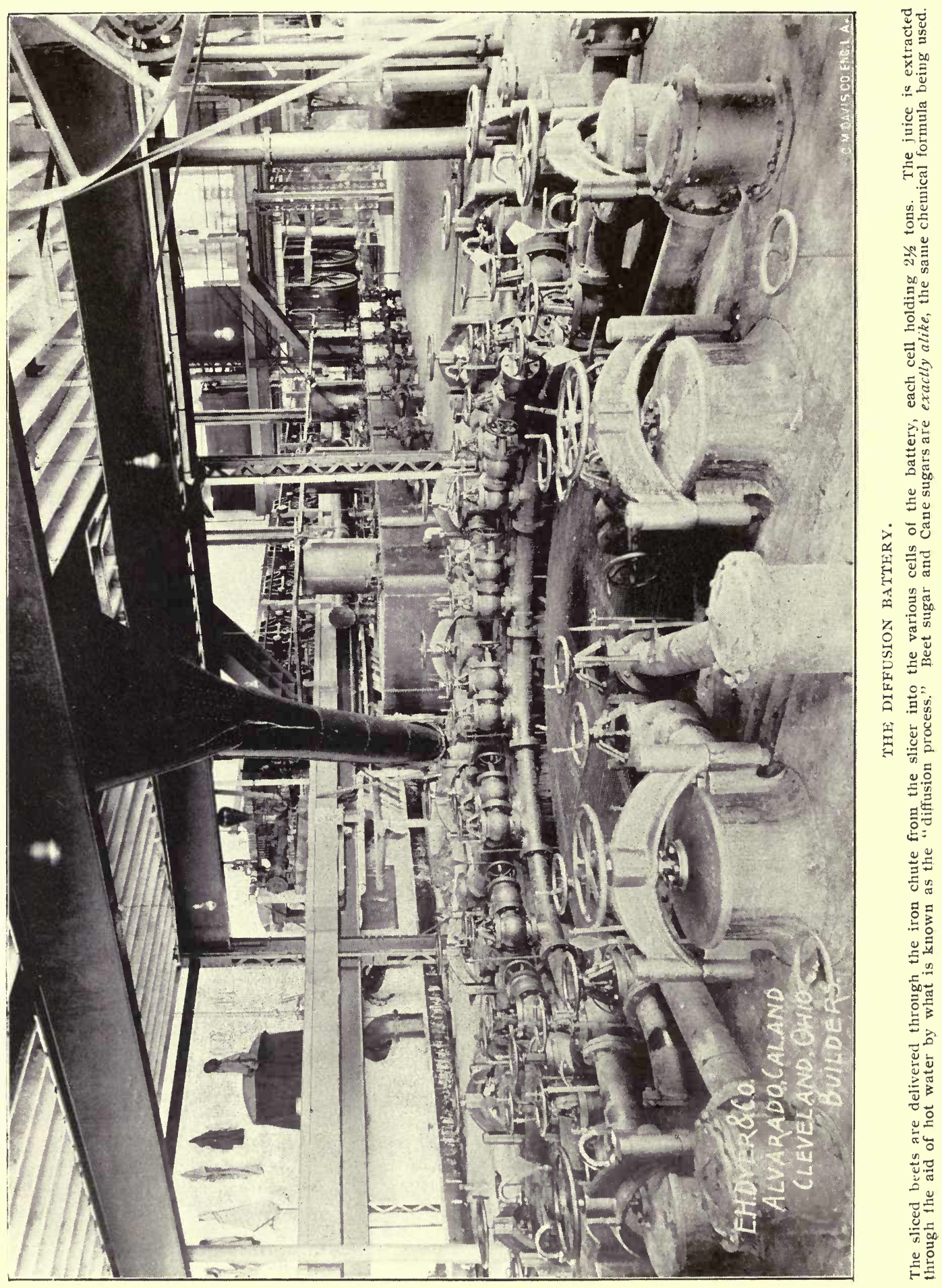


When the plants are about two inches in height it will be discovered that there are too many in the row; it is then time to thin the plants to a uniform distance. This is done most economically by having hoes cut to 4 inches in width and made sharp. One man with the hoe will strike out the spaces for two or three "thinners." He leaves the little beets in bunches, 6 to 8 inches apart. The "thinner" deftly pulls out all but one. More than one beet in a place means ruin to the whole bunch. In the struggle for mastery they become twisted around each other and none are worth harvesting. So never leave but one beet in a place. In poor land thin to Io inches apart; in fairly rich soil 8 inches is best; in very rich land, 4 to 6 inches is to be preferred. Large beets are not desired.

The thinning in small beet fields can generally be done by the family of the farmer, but must be done quickly, and it is economy to hire labor rather than put the work off until the beets have attained much size, as the pulling out of the surrounding beets leaves the survivor in a weak condition, which is not noticeable when the plant is just beginning to send its root down into the earth. In large fields the thinning is done by contract, the price varying from $\$ 3$ to $\$ 5$ per acre, depending entirely upon the stand, the condition of soil, weeds, etc.

After the thinning the plants will look weak, and it will be forty-eight hours before they have gained strength to hold their heads up.

Cultivation.-Now begin the cultivating with the horse hoe; the old fashioned corn cultivator must not be used. The Moline beet cultivator is the best yet made. You cannot cultivate too often. Keep the ground mellow, the weeds down, and nature will do the rest. Do not hill the beets. The crown of the beet, from whence the leaves branch out, should never be covered with dirt, nor should the cultivation bring the dirt away from the beet. When the leaf surface is large enough and the ground almost covered, the work with the horse and cultivator is done; to lacerate the leaves by further use of the horse would injure the plant. But later, weeds must be pulled, and one man can be kept busy all the time on twenty acres, until the harvest time has come, cutting or pulling weeds.

Maturity of the beet can only be determined by the chemist, but ordinarily, when that period arrives, the dark green of the leaf disappears, the outer leaves wither and die, and the central leaves turn a golden yellow, save very late in the season, when these notable indications of maturity are absent; yet the analysis shows high sugar with a corresponding co-efficient purity. When the chemist discovers that the beet is from I 4 to 20 per cent. sugar with co-efficient purity 80 to 85 , the sooner that crop is harvested the better.

But it is not possible to harvest thousands of acres at once; the factory can only consume its quota; the beet sheds and pits will only hold a few thousand tons; then comes the necessity for wisdom on the part of the field superintendent. He must distribute the order for beets among all the ripe fields, showing no partiality. It is far better for the farmer to be ready, and rush his harvest when his order comes, and best results are only attained when the factory and the farmer work together. This means: the farmer plows and plants in proper season, is never behind in his work, never undertakes more acreage than he can well handle with profit. There can be no question but that small farm units are best for all concerned.

With the harvesting comes the need of a suitable wagon. The tires should be at least 4 inches, with axle trees strong enough to support five tons of beets. An extra bolster is put on, that the body frame may be set up high enough 
to extend the box out over the top of the wheels. The frame should be of $2 \times 8$ timber, of good tensile strength (Oregon pine is well suited). The $2 \times 8$ are set on edge; firmly bolted upon these, at both ends and in the middle, are three $4 \times 4$ cross pieces reaching out even with the end of the hub; upon these cross pieces bolt Ix3s, leaving a space between each of at least $3 / 4$ of one inch to permit the dirt to shake through. The ends are securely bolted to the standards-rigidly bolted to the $2 \times 8$. The sides are made of $2 \times 4$ with $\mathrm{Ix}_{3}$ bolted thereon, as the bottom was made; but the sides are attached to the body on the lower sides by heavy forged hinges, three on each side, with eyes and bolts at each end to hold the sides firmly in place while the load is on.

This constitutes the strongest and most convenient box yet known; and the sides hung upon hinges facilitates the quick unloading at the factory, which is accomplished by making the platform by the side of the beet pits, a series of tilting sections, by which means the wagon is tilted by a system of weights and pulleys at such an angle that the beets are in a second dumped into the pit, the side boards acting as an apron, as is shown in the very apt illustration.

BEET Plows. - The other important harvesting tool is the plow, and it is well to suggest, as unwise, to try to plow out the beet crop with an ordinary plow. The loss in roots broken off in the ground and those missed entirely, will more than pay for a suitable plow in harvesting any considerable acreage. The ordinary sub-soiler, furnished by the trade, of which the beet plow is a type, is not built strong enough to stand the test. In California and in Utah, the local smith has made the most serviceable tool at a cost of about \$12.00 each. There is another great advantage in the use of the beet plow of the sub-soil type, it breaks up the subsoil in a way to promote the better growth of the next crop.

Topping.- In topping, a well riveted, strong butcher knife, with a Io-inch blade, is fully as competent to perform the work well as a costly knife made expressly for that purpose. The plow lifts the beet root partially out of the ground, so that it can be easily grasped by the left hand of the topper, while with his right hand he deftly cuts the tops off at one blow, cutting just below the lowest leaf growth. A little practice makes the worker very expert.

BEDS FOR THE TOPPED BEETS. - The plow is, perhaps, one hundred rows ahead of the toppers. A man precedes them with a rake; at frequent intervals he removes the beets a little, making a bed about 6 feet across, with a smooth surface, if the crop is good, these beds are about 30 feet apart and are in a perfectly straight row. The reason for this is obvious. The topper throws the finished beet to the bed where it is ready in heaps for the loader, unmixed with leaves or clods of dirt. The leaves are very objectionable to the factory superintendent-they clog the knives in the slicer, and in other ways hinder the operation. The clods of dirt plus the leaves, cause extra tare in determining the net weight of the farmer's load. Be sure that the beets are in snug, clean heaps, and you will facilitate all interests involved.

The detrimental solids, or salts, absorbed by the beet in its growth, centralize in the top of the beet, particularly in that portion grown above the surface. If the topping is properly done, all that portion grown above ground is cut offsquare across. Then the analysis of mature beets will ordinarily show a satisfactory coefficient of purity, which should always be above 80 . The beet tops are of 


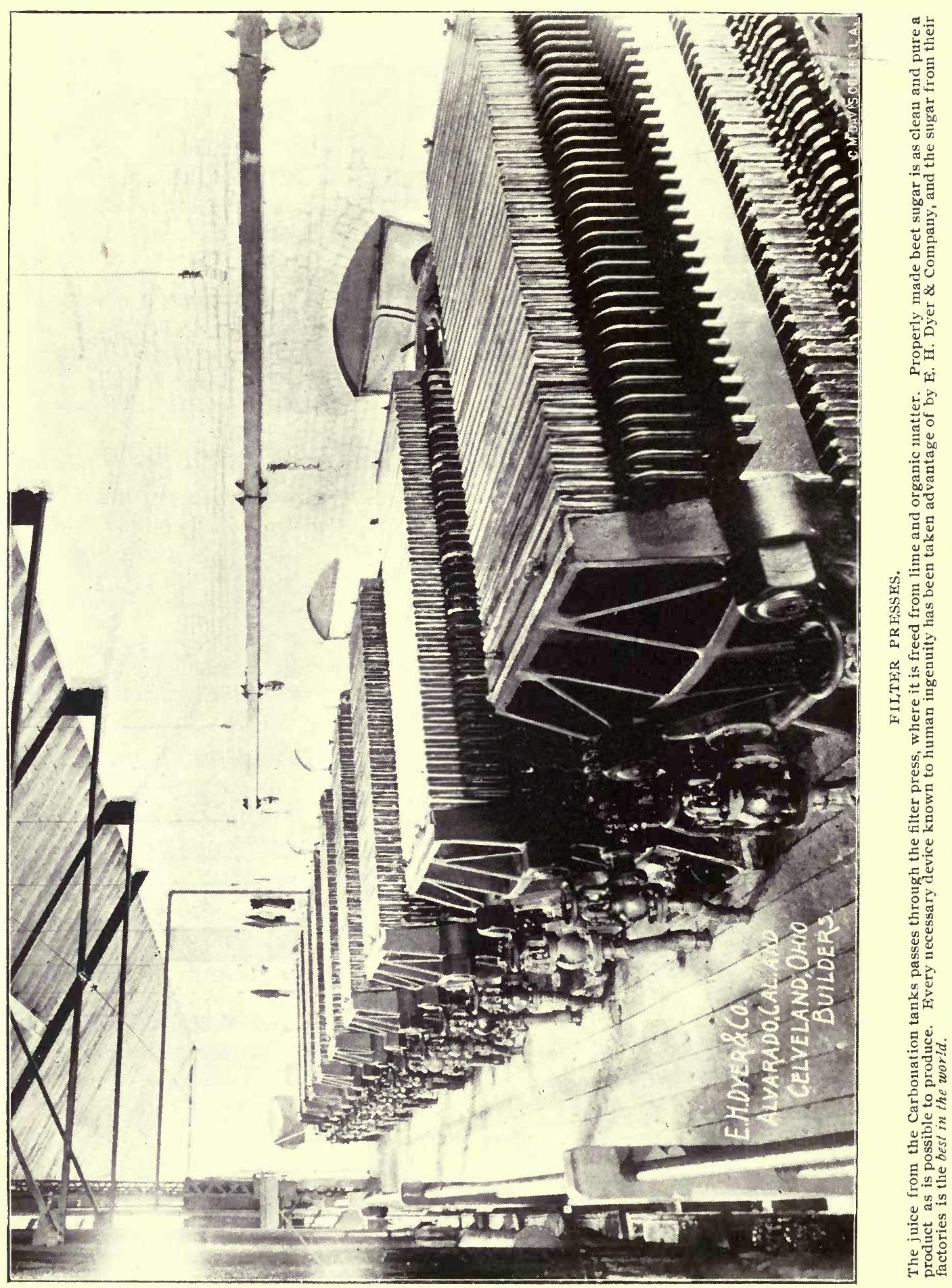


great fertilizing value. It is dangerous to allow them to be used for stock feed; they must be plowed under as soon as possible after the beets are removed from the field.

I give the following extract from a Traite de la Culture de la Betterave a sucre, by G. Dureau, showing the estimation in which beet tops are held for fertilizing purposes in older beet-raising countries :

"On a well conducted farm the beet tops and leaves should be well looked after. We have shown that the leaves and tops of rich sugar beets equal 50 per cent. of the weight of the roots. If we take, for example, a yield of 50,000 kilos. of beets to the hectare (22 6-20 tons to the acre), with, say, 25,000 kilos. ( I I 3-20 tons per acre) of tops and leaves, the latter will contain $95 \mathrm{~kg}$. of nitrates, $63.75 \mathrm{~kg}$. of phosphoric acid and $270 \mathrm{~kg}$. of potash (or say, $85 \mathrm{lbs}$. nitrates, $57 \mathrm{lbs}$. of phosphoric acid and $24 \mathrm{I}$ lbs. of potash to the acre).

"On account of their richness in nitrates, phosphoric acid, potash and other more or less useful elements, the beet tops are an excellent fertilizer, and in every instance should be restored to the field that produced them by plowing them under while green. Different experiments have proved that it is better to plow them under green than dry.

"If the beet tops are not restored, the value of the elements lost to the land may be estimated as follows: Phosphoric acid at $0.50 \mathrm{fr}$., potash at $025 \mathrm{fr}$., nitrate at I. 50 fr. per kilo., or say a loss of $24 \mathrm{I}$ fr. per hectare for a yield of 50,000 kilos. of beets (\$I 9.50 per acre for a yield of 22 6-20 tons).",

It is therefore, a serious mistake to underestimate the benefit of beet tops as a fertilizer. They are of great value, and every farmer that restores them to the soil realizes a double profit in the chemical and physical improvement of his land.

"We speak of the per cent. of sugar in the juice and the coefficient of purity. Let us understand the meaning of these terms. A hundred pounds of sugar beets contain about 95 pounds of juice. This juice not only contains sugar, but various other substances, largely mineral matter, which are a great hindrance, causing serious losses of sugar during the manufacture. A hundred pounds of average beet juice will carry about I 5 pounds of solid matter, of which I 2 pounds may be sugar and three pounds matter not sugar. If we divide the number of pounds of sugar (I2) by the total number of solid matter ( I5) we get 0.8 , which sum is called the coefficient of purity; that is, beet juice with I 5 parts of solid, I 2 of which are sugar, is said to have coefficient of purity of 80 . If the sample of juice contains 16 parts solid matter and I 2 parts sugar, as before, then the coefficient of purity is only 75. When reducing the beet juice to make sugar, each pound of foreign matter, not sugar, prevents at least 3 to 5 per cent. of sugar from crystallizing."

THE FOLLOWING ACCURATE AND STRICTLY UP-TO DATE EXPLANATION OF HOW SUGAR IS MADE WILI, DOUBTLESS INTEREST MANY :

A Short Description of the Process of Extracting Beet Sugar is as follows: The beets are delivered by wagon and weighed, the weighed beets are unloaded in storage bins with sloping bottoms, through which runs a stream of water confined in a flume with a movable covering; the beets are allowed to fall into this flume, the water floating them to the factory, where they fall into an elevator, which drains the water and elevates the beets to a washer; here they are subjected by means of propeller arms to a thorough washing, after 


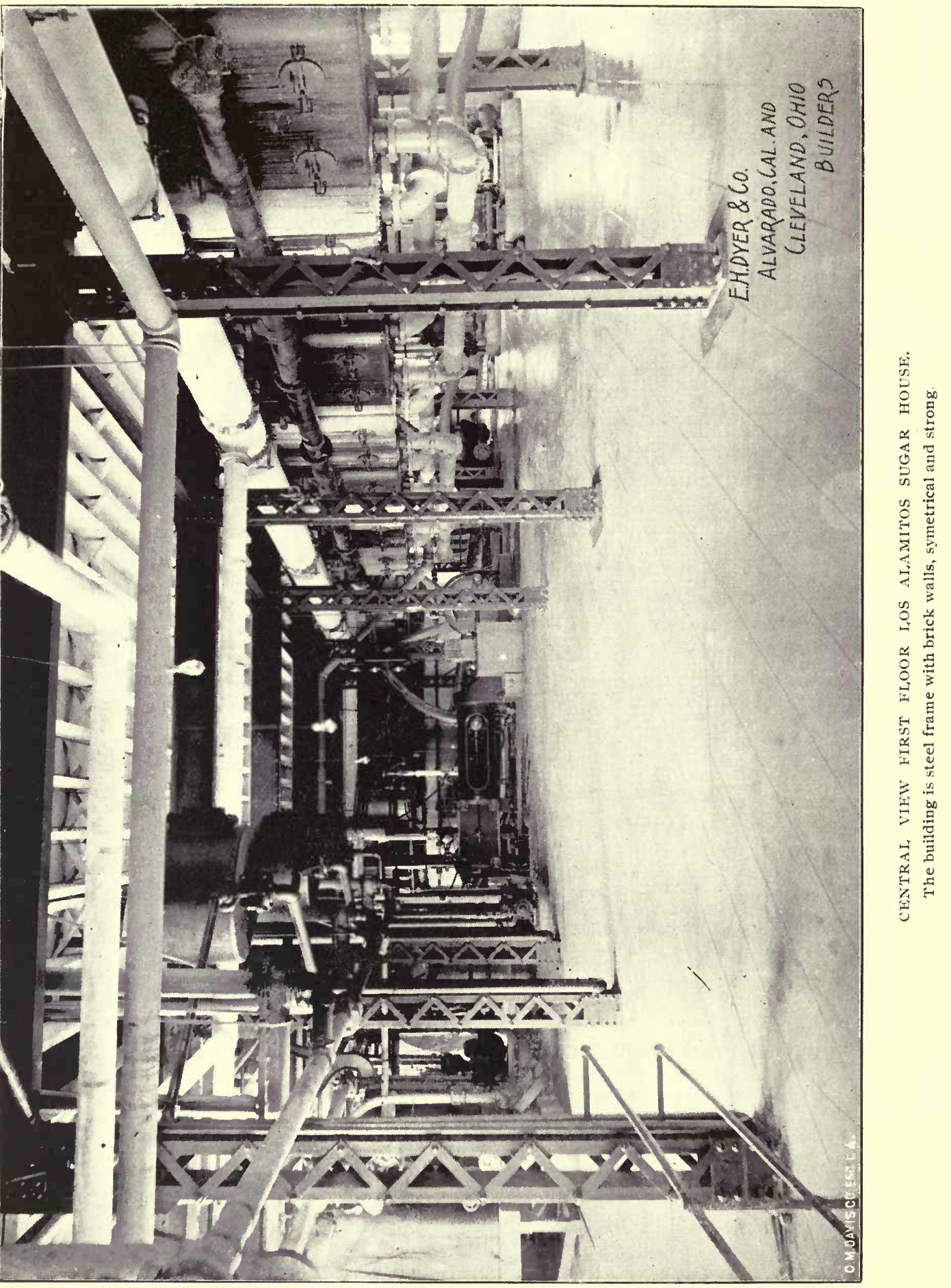


which they are automatically ejected into an elevator, which carries them to the third floor, where they fall into a slicer.

THE SLICER.- In this machine the beets are cut into long v-shaped strips about $5 / 8$ of an inch wide by $1 / 8$ of an inch thick and of various lengths.

DIFFUSION BATTERY.-From the slicer the beets are transported by gravity through a chute to the diffusion battery (which consists of 14 tanks connected by piping and valves, each holding $2 \mathrm{~T} / 2$ tons of sliced beets), where the sugar is extracted by a series of leachings with hot water. The sugar is held in solution in the cells of the beets. These cells also contain most of the impurities. The object of the diffusion process is to obtain the sugar with as few of the impurities as possible. First, in the cutting, the machine and the knives are selected with a view of cutting the beets in such a form as to rupture as few cells as possible, and at the same time prepare a large surface for the action of the water or dilute juice in the operation in the battery, without destroying the rapid circulation of the liquid.

In the raw state the protoplasmic lining of the sugar cells will retain the sugar even if it be immersed in water, but upon heating, a change will take place, and the cell that previously prevented the process of diffusion will readily permit the sugar to pass out into the water, until the water on the outside of the cell contains the same percentage of sugar as that on the inside. If this water is then drawn off and replaced with fresh water, this process will again take place and may be continued until no more sugar remains. If the operation was carried on in this way, all of the sugar could be extracted, but there would be a large quantity of dilute juice.

To secure the same results without so great a quantity of juice, fourteen diffusion cells are employed in the factory herein illustrated, each holding $2 \mathrm{r} / 2$ tons, being about 6 feet diameter by 8 feet long. They are arranged in a circle for convenience in filling with fresh sliced beets (cossettes), and discharging those exhausted of sugar (pulp). Each cell has adjoining it what is termed a "heater". This heater is about 18 inches diameter by 8 feet long, filled with brass tubes, arranged so the juice may be heated by the admission of steam without contact with the juice. The fourteen cells and heaters are so connected by piping that either water or juice may be admitted to any individual cell, or caused to circulate through them all ; the whole arrangement is termed the "diffusion battery."

THE STRUCTURE OF THE BeETS.-In the cell of the beet is not only sugar (crystallizable body) but salts, albuminoids and other undesirable substances (colloid bodies); as it is only the crystallizable bodies that have the property of diffusing through the cell membrane, it is desirable to have them remain intact, therefore great care is taken to rupture as few cells as possible in slicing the beets ; also to avoid bursting the cells by overheating during the process of diffusion. The temperature at which diffusion takes place is from 70 to 85 degrees $\mathrm{C}$. - I 58 to I $85 \mathrm{Fah}$.- depending on the quality and character of the beets. If the process is properly conducted, there will be a partial clarification of the juice and the purity of the diffusion juice will be higher than the juice in the beet.

The Process of Diffusion.-The operation is conducted as follows: First from ten to twelve cells are filled with slices, water that has been previously heated to the desired point (say 80 C.) is admitted till the cell is filled. Assuming that the slices contain I 4 per cent. sugar, there is an interchanging of the sugar in the cell 


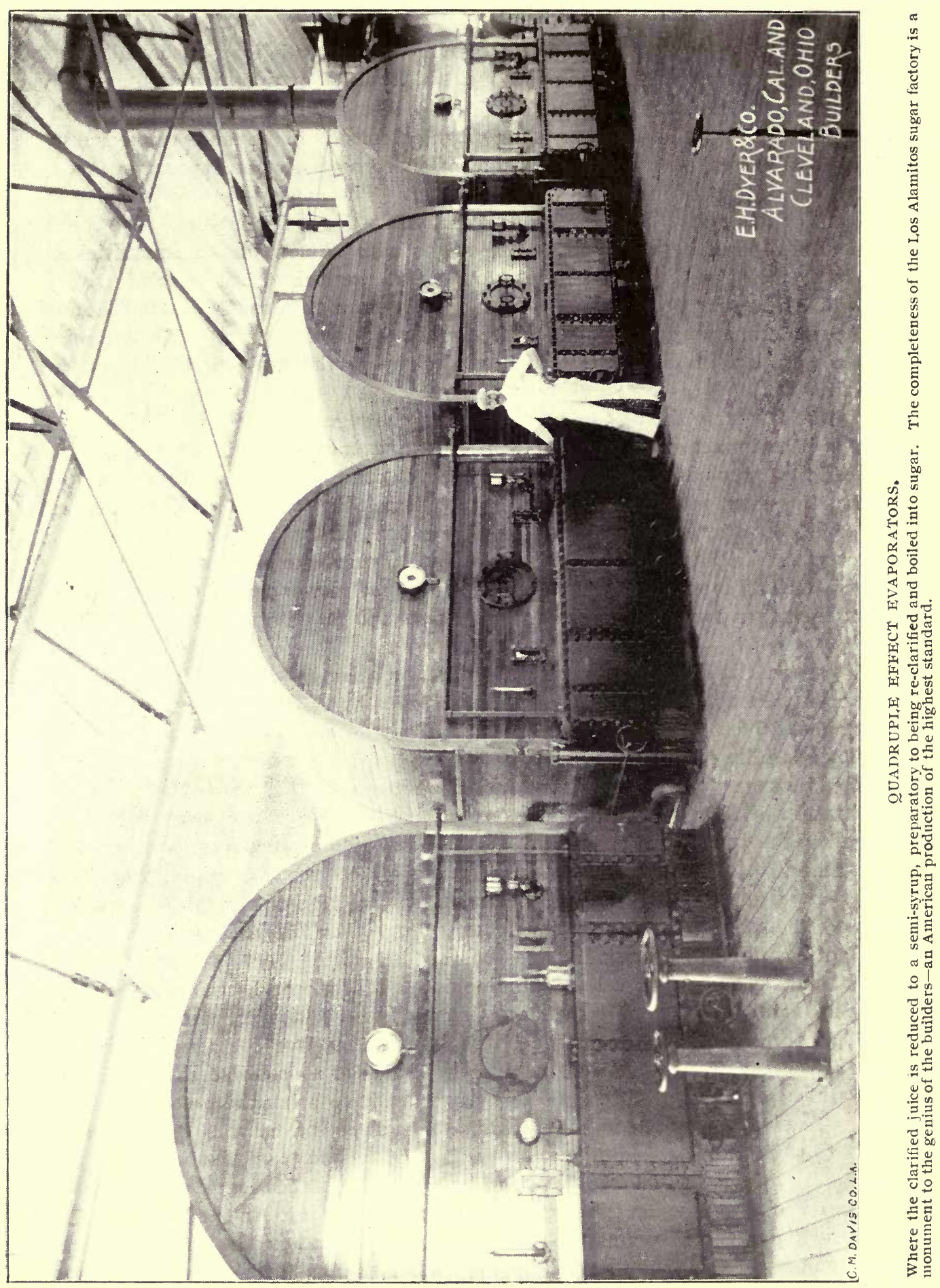


to the water outside, till there remains 7 per cent. in the cell and 7 per cent. in the water ; this water, which now is a dilute juice, is forced by gravity into the next cell. Having been heated in transit to $80 \mathrm{C}$., there is again an interchanging of sugar from the sugar cell to the juice; this time the water admitted having already 7 per cent. sugar will extract but half of the difference between the sugar in it and in the beet, and there will be 0.5 per cent. sugar in both water and slices; this is again forced over to the next cell of fresh slices, and again there is an interchanging or evening up, and there will be 12.25 per cent. sugar in the juice; and so on till this water has passed over eight to ten cells, when it becomes nearly as concentrated as the beet juice.

To go back to the first cell, in this we had slices with 7 per cent. sugar and 7 per cent. sugar in the water; this water was forced over to the next cell by means of fresh water; this water again eliminated half of the sugar, and there remained but $3 \frac{\mathrm{T}}{2}$ per cent. sugar; when the third cell was filled it was done by forcing water in cell No. I, which in turn being connected, forced the liquid contents of No. 2 into No. 3, and so on. This fresh water that for the third time has been admitted to cell No. I again extracts half of the sugar, leaving I.75 per cent sugar in both water and slices. This process is carried on till there remains from 0.5 to 0.25 per cent. sugar in the slices, when they are emptied by a door at the bottom of the cell, when the cell is refilled with fresh slices to be again subjected to the same process.

Carbonation Process.-The juice when sufficiently concentrated is drawn off by measure, taking enough to extract the sugar without too great a dilution; this is accurately measured and a record kept of the time, number of cell, and density. This juice flows by gravity into a heater (calorisator) where it is heated to $190 \mathrm{Fah}$. This is important, as it is necessary to coagulate all albuminoids before the presence of lime. From the "heater" the juice flows to the "carbonator" (a large closed tank with suitable valves and appliances for admitting the juice, lime, carbonic acid, etc.). To the heated juice there is admitted from 2 to 3 per cent of lime in the form of milk of lime (22B.); this lime combines with the greater part of the impurities and forms an insoluble precipitate. The action of the lime is complex, and it is not necessary to go into the minutiæ in an article of this kind.

The Use of Carbonic Acid Gas.-The lime also combines with the sugar, forming a sucrate of lime, which if not decomposed would be lost during filtration; this is done by injecting carbonic acid gas, which is made in burning the lime used in clarification, forming an insoluble precipitate of carbonate of lime. Just enough gas is admitted to break up this combination of lime and sugar ; care is taken not to carry the operation too far, as after the sucrate of lime is destroyed, the carbonic acid attacks other compounds of lime, and in time would iiberate all the impurities again. The process is closely watched, and samples are taken every few seconds as the operation approaches completion. The samples are taken in a test tube, the proper point at which to stop the flow of carbonic acid gas is shown by the formation of a granular precipitate, showing clear liquor between the particles; the gas is then instantly shut off, a test sample is sent to a table near by, where a chemist assistant is stationed, and the per cent. of lime in the juice determined by a standard acid. 
Filter Presses. - The physical condition of the precipitate is important; if the operation has been carried on properly, the juice will filter rapidly through the filter presses, leaving a hard lime cake that is easily washed and cleaned from the presses, but if improperly done, there will be a flocculent, gelatinous precipitate. The filter press consists of a series of frames and screens, alternating; the frame is a hollow iron square; its purpose is to receive and hold the lime precipitate. A corrugated plate is covered with a screen, which is covered in turn by the filter press cloth; the corrugation and screen is to prevent the collapse of the cloth and admit of the juice percolating through it.

After clarification (or carbonation, as it is called in a beet-sugar house) the whole contents of the carbonator, juice and precipitate, are drawn off and forced through filter presses by means of a pump, at a pressure of $60 \mathrm{lbs}$. per square inch, the whole compressed by means of screws or hydraulic pressure; this is to make tight joints between the frames, and does not in any way compress the contents of the press when working. The juice is forced into the frames of the press by the afore-mentioned pump, the clear juice passing through the cloth into the screen, from which the filtered juice passes to a trough, through a cock in the screen ; this is continued till the frames are completely filled with the lime precipitate, when the flow of juice into the press is stopped, and hot water forcd through instead, till the adhering juice is washed out of the lime cake and cloths; the press is then opened and the lime cake removed, when the press is again closed and is ready for further use.

Second Carbonation.-The juice, as well as the wash water from these filter presses, is received in another set of carbonators, where about $\mathrm{I} / 2$ of I per cent. milk of lime is again added; this time there is not so much danger of over carbonating with carbonic acid gas, which is passed through the juice till there remains but from 0.025 to 0.05 per cent. lime in the juice; this is determined by actual test each time; the juice is then boiled to precipitate the double carbonate that may be in solution, and again forced through another set of filter presses.

Sulphitors. - The clear strained juice, which is now a light straw color, is pumped to the sulphitors, which are somewhat of the same construction of the carbonators; here sulphurous acid gas is forced through the juice by means of an air compressor, which decolorizes the juice and precipitates the remainder of the lime ; this juice, which is now water white, is allowed to flow through mechanical filters which eliminate whatever mechanical impurities remain in the juice. At this stage the juice, while comparatively pure, is dilute, containing from 3 to ro per cent of sugar, dependent upon the quality of the beets being worked; it is desirable to concentrate it, which is done in a multiple effect evaporator.

THE EvaporaTOR.- The quadruple effect evaporator consists of four bodies, each of which is arranged with a steam chamber and tubes, with room for the vapors to disengage ; the upper part, or vapor chamber of each body is connected with the steam chamber of the next body, so the vapors from the boiling liquor may pass into the steam chamber of the next.

The operation of this apparatus is as follows : The liquor space of each body is filled with juice, and the exhaust steam from the different pumps and engines throughout the house are collected in a pipe which supplies the steam chamber of the first effect with steam, which causes it to boil; the boiling juice and the vapor 


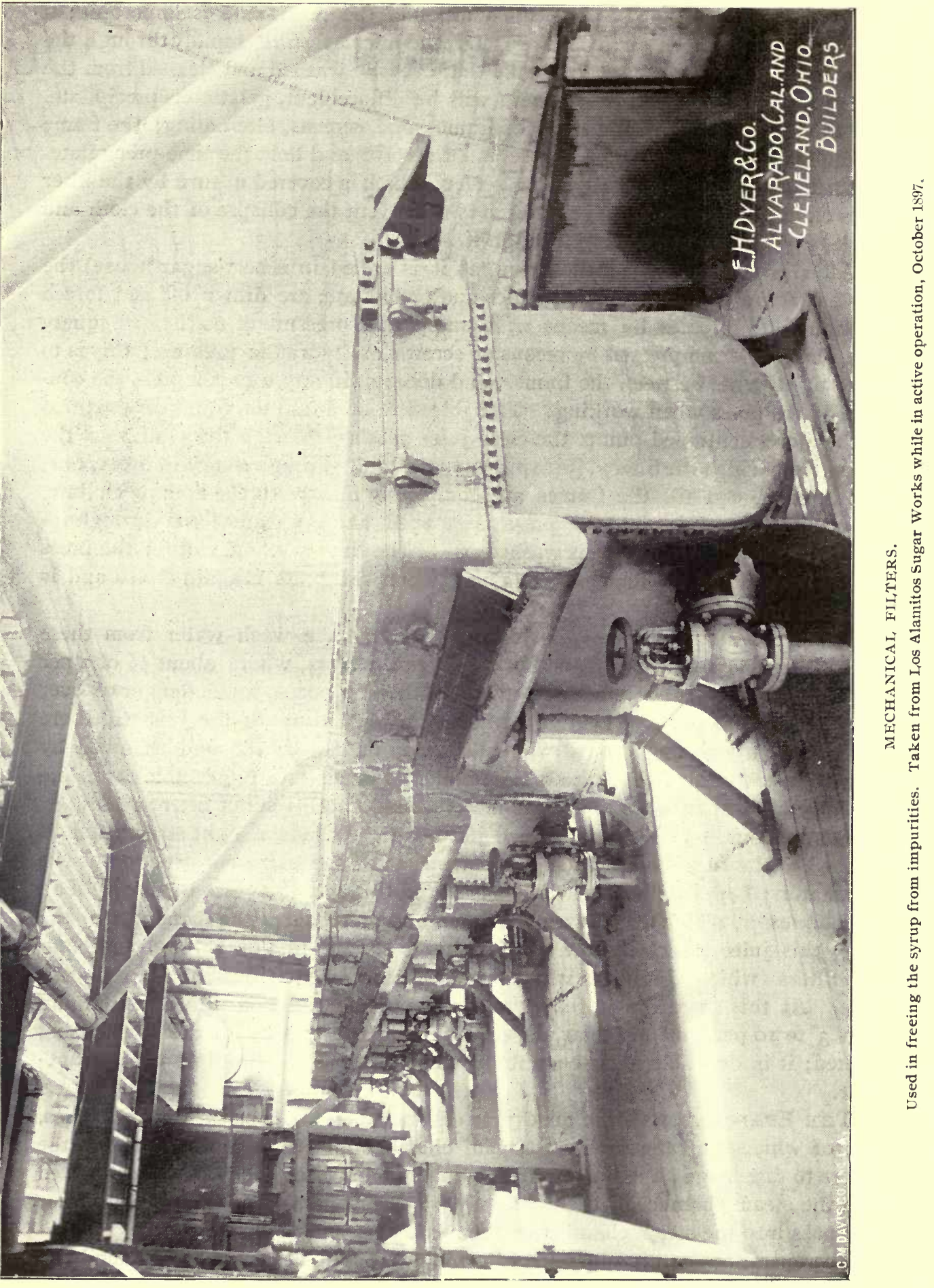


rising from it have a temperature of about Ioo C., which passes over to the steam chamber of the next body and causes it to boil; the steam arising from it has a temperature of about 88 degrees, which passes over to the steam chamber of the third body causing it to boil; the temperature of the steam arising and passing over to the fourth body has a temperature of 76 degrees, which causes it to boil. The difference in temperatures at which the liquid boils in each body is caused by the difference in pressure, which is maintained by means of a condenser and vacuum pump; the vapor arising from the last effect or body passes to a condenser producing a vacuum in the last body of about $26^{\prime \prime}$, the liquid in the last effect thereby boiling at a temperature of $60 \mathrm{C}$. The fourth acting as a condenser and producing a vacuum to the third, the third for the second, and the second for the first.

The juice, flowing through the four effects, becomes more condensed as it passes along, going in at a density of about ro, and coming out at 5o, which not only concentrates the sugar, but the impurities; this, which is technically called "thick liquor," is again submitted to the fumes of sulphurous acid, which neutralizes it, destroys coloring matter, etc. The "thick liquor" is again passed through mechanical filters that remove any solid foreign matters, after which it is boiled in the vacuum strike pan where the sugar is crystallized.

VACUUM PAN.-The "vacuum strike pan" is a closed cast-iron vessel, about I I feet in diameter and I4 feet high, and holds 35 tons of "melada" (sugar and molasses) when full.

In the lower portion are situated a number of copper coils through which the steam passes without coming in contact with the boiling mass; the vapor arising passes to the condenser; a pump draws off the non-condensable vapors. During the operation a vacuum is maintained in the apparatus, the mass boiling at a low temperature, which prevents burning. The operation is as follows :

Juice is admitted to the pan, and when about half full steam is turned on and the contents evaporated till it is "just about to sugar" (as would be said in a maple camp); at this moment fresh juice is admitted, and the whole mass thinned, but not enough to dissolve the microscopic crystals; it is again allowed to concentrate by evaporation, thickened, and the sugar in the freshly admitted juice will join the microscopic crystals, which increasing in size will now be apparent to the eye; the mass is not allowed to concentrate enough to form more microscopic crystals, but again thinned by adding fresh juice before that point arrives which causes the crystals to grow in size without forming new ones; this operation of concentrating and diluting the mass goes on till the "strike pan " is full, the size of the crystal and the hardness depending upon the way in which the operation is conducted. It is at the will of the operator whether large, small, hard or soft crystals are made ; by keeping the average of the boiling mass thin, the crystals will be large; thick, they will be fine; hot, they will be hard; cool, and they will be soft.

When the operation is complete, the whole mass ("magma") is concentrated till it contains about 75 per cent. sugar and 25 per cent. molasses (the latter being 7 to ro per cent. water) in its composition. The steam is then shut off, air admitted, and a large valve at the bottom opened, the entire mass, weighing 35 tons, allowed to run out as soon as possible before it has time to solidify.

The MIXER.- The "magma" falls into a large iron tank, with revolving pro- 


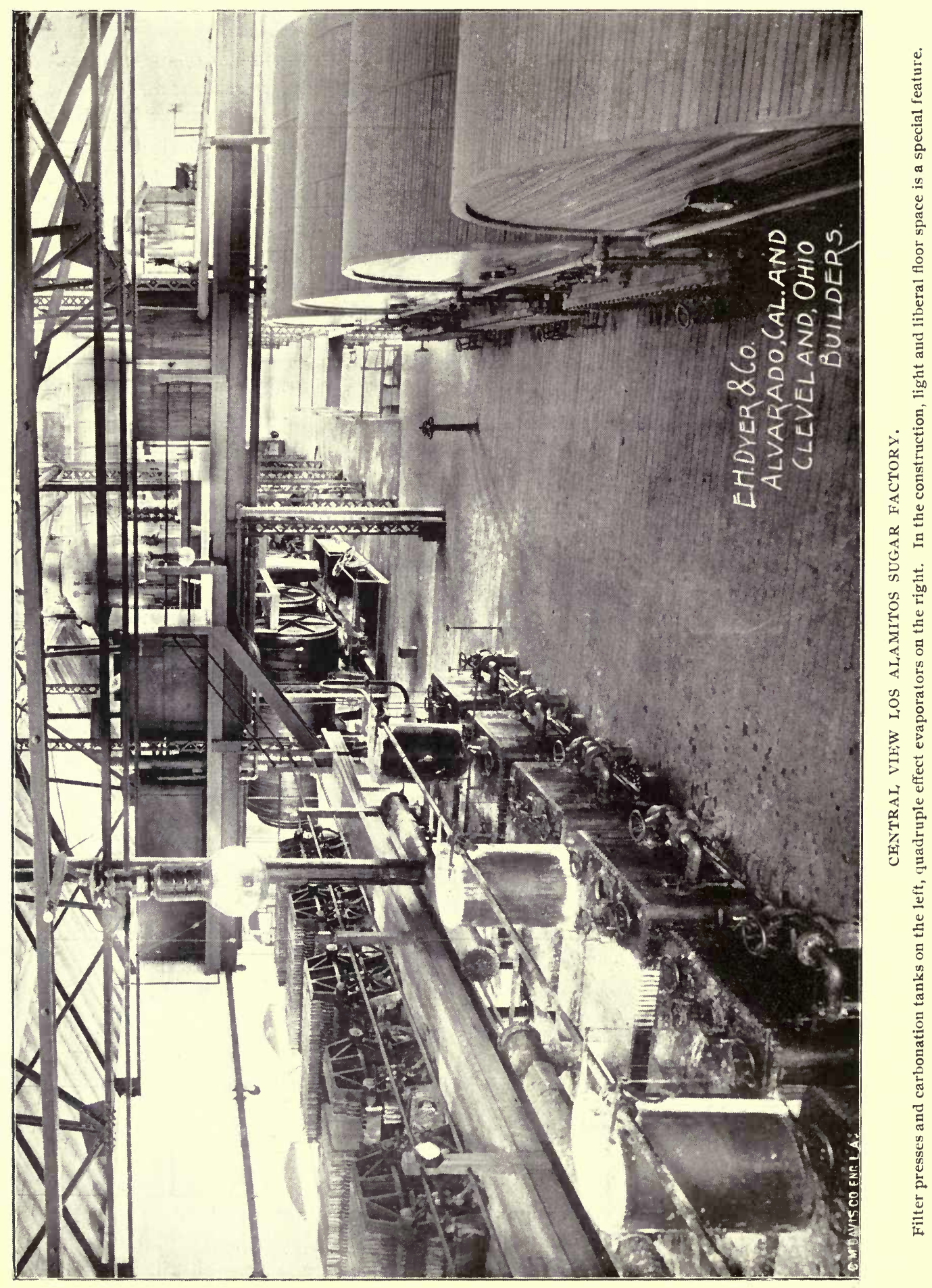


peller arms constantly revolving, which is termed a "mixer." Attached to and directly underneath the mixer, are 8 centrifugals, 40 inches diameter.

THE Centrifugals. - These machines consist of revolving "baskets " surrounded by safety curbs; the baskets are lined with a finely perforated brass screen. About 500 pounds of the "magma" is taken into a centrifugal at a time ; the machine is caused to revolve by means of suitable belts and pulleys till it attains a velocity of Iooo revolutions a minute; the centrifugal force, which is about 40 pounds per square inch, throws the "magma" to the sides, the screen holding the sugar back, the molasses is thrown off through the screen till it strikes the sides of the safety curb, flows off in a pipe at the bottom, and is collected in tanks for further manipulation.

After the "magma" has been in the revolving centrifugal a few minutes, it is entirely freed from syrup, then a jet of water is sprayed on it to remove the last trace of molasses, the machine is stopped, and the sugar falls through an opening in the bottom into a conveyor which carries it to an elevator connected with the dryer.

THE DRYER.-The "dryer" is a hollow iron cylinder 6 feet in diameter by 30 feet long, which revolves slowly; this motion causes the sugar to be continually dropped on warmed pipes, which, with a current of hot air that is forced through it, completely removes every vestige of moisture from the sugar ; the sugar passing from the "dryer" goes over a screen which removes any lumps that may have formed, and falls into a hopper from which it is sacked or barreled and is ready for the market.

The molasses that came from the "magma" is again boiled in the vacuum strike pan, and another crop of sugar obtained from it, and also another lot of molasses ; this second lot of molasses is too poor in sugar to be again crystallized in the vacuum pan ; it is, however, concentrated to what is called "string proof" in the vacuum pan, and dropped when finished into crystallizers, where it is continually agitated, which, with careful attention to temperature, causes all sugar that can be obtained to crystallize.

OLD METHODS.-The usual custom (instead of recovering the last sugar by means of crystallizers) is to deposit it in tanks, where, if remaining six months, it would gradually crystallize ; but by the use of "crystallizers" the last sugar can be obtained in four or five days.

There is yet remaining a molasses too poor in sugar to be used except by separate and expensive operations, the desirability of which depends on the price of sugar recovered.

The cheapest and most popular being the "Osmose" process : the molasses, in suitable machines, is made to pass over a specially prepared parchment ; on the other side is a current of hot water; the salts that dissolve more readily than sugar diffuse through this membrane to the water with which it is carried off; the molasses which had been too impure to crystallize, now having become rid of some of its impurities, will again crystallize; this operation is carried on till there is no molasses remaining.

The other is the "Substitution" process, and is based on the fact that finely divided quick lime will, when in the presence of sugar, at a low temperature, form an insoluble combination (sucrate of lime); this sucrate, when formed, is recovered in filter-presses-same as before described-the impurities washed away 


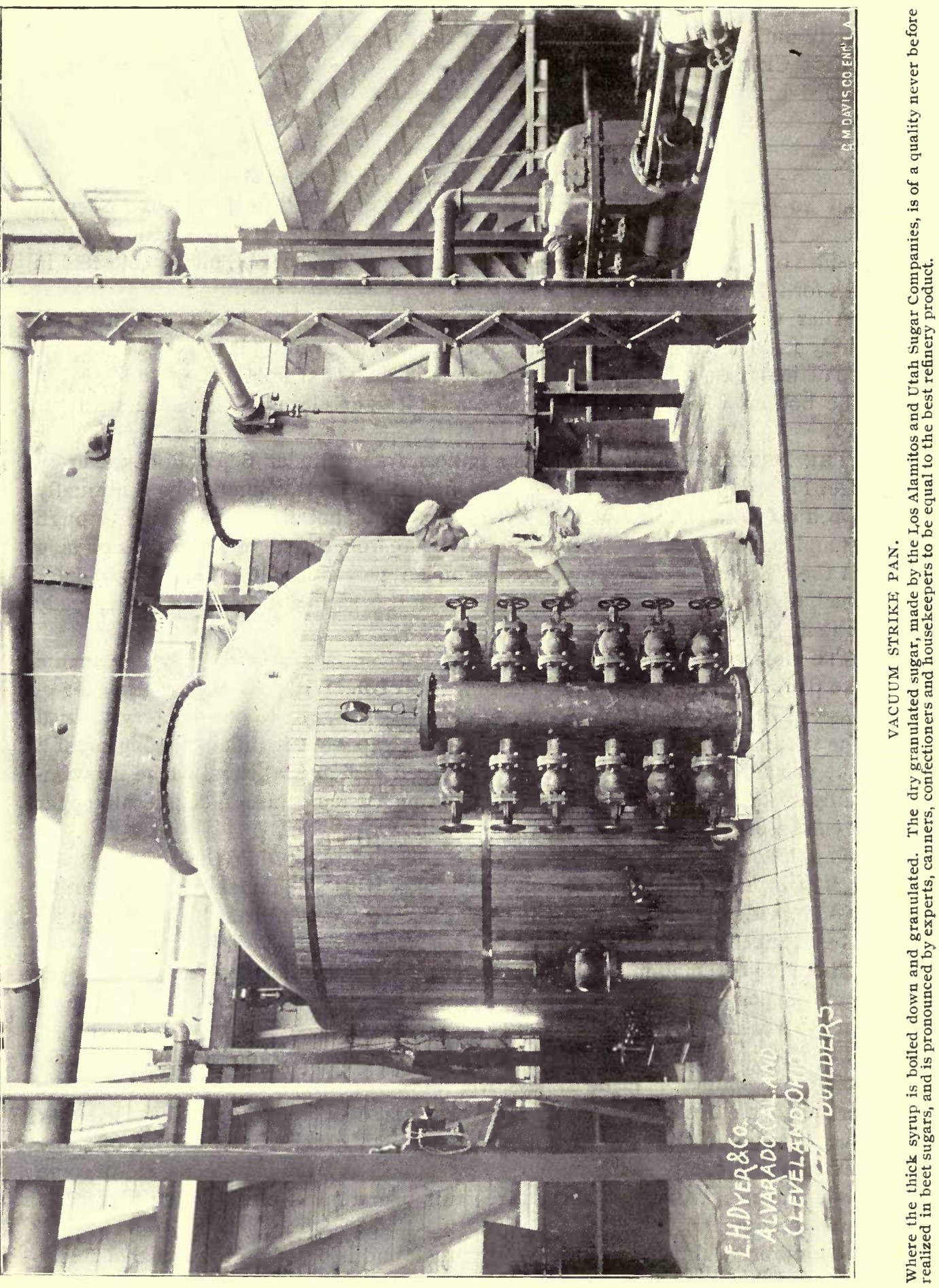


with water, and the sucrate used to clarify the juice instead of lime, the sugar being freed by carbonic acid gas as described under carbonation.

This is, briefly, how beet sugar is extracted and made equal in quality to the finest refinery product. Technically it is "Cane Sugar." (See U. S. Dispensatory.)

\section{ITEMS OF INTEREST.}

How THE TARE IS ARRIVED AT.-At the laboratory the tare man assorts the different samples, by contract number; if there be more than one sample, they are mixed and an average fifty-pound sample is taken, weighed, washed and reweighed; the difference in weight, multiplied by two, gives the tare per cent. Each weight is multiplied by the polarization, and the sum of the products, divided by the total weight of the beets, gives the average weight of sugar.

Why BeEts With Purity Below 80 ARE OBjectionable AND ARE OF NECESSITY REJECTED.-In a previous paragraph, it has been explained as clearly as possible what "purity" means, and how it affects the crystallization of sugar. Farmers frequently complain that it is not neceseary to reject beets of 75 purity when 80 purity is the standard. Perhaps the fact that the waste molasses from which the factory derives no revenue whatever analyzes 46 to 48 per cent. sugar, with 57 to 60 purity, may illustrate the truth that beets with 12 per cent. sugar and 75 purity are not desirable ; the percentage of sugar crystallized is so small that it is unprofitable, if not an absolute loss of money, to process them at all.

The extraction of sugar is one of the fine problems in chemistry, dealing with almost infinitesimal fractions in quantities and results. The results of the campaign, whether to the profit side of the ledger, or to the contrary, depend solely upon the laboratory; that is, providing the general business management is what it should be. It is not to be expected that the farmer, as a class, will fully comprehend the matter, but experience and close observation will finally make this and other vital matters connected with this great business clear, and distrust will disappear.

Profits. Farmer vs. CApital. - A crop that yields, gross, from \$40 to \$100 per acre in comparison to other field crops, is of itself a convincing argument, and in proportion to the risk is fully equal to the factory proportion of the profits.

If capital is to be invited into this new field of enterprise only upon the condition that it will share equally with the grower all that can be made in the business, one of two things will happen,- - capital will not invest at all, or capital will own both land and factory.

The price of beets will unquestionably remain about $\$ 4$.oc per ton at the factory unless a very low sugar market forces the price down, which is not likely, as the price of refined sugar in the United States to the consumer is very low as compared with foreign countries.

Sugar Production and Consumption.-- "It has been alleged that sugar production is already overdone ; witness the present low price of its product. While it must be doubted that sugar will again rise to the high prices that have ruled in the past, it is also true that the low prices will continue to stimulate and increase consumption. Within the easy recollection of the present generation sugar was a luxury, too costly to be used otherwise than sparingly, and diligently claimed to be particularly injurious to children in general, whose natural appetite craved a more liberal allowance of what is now justly considered an alimentary 


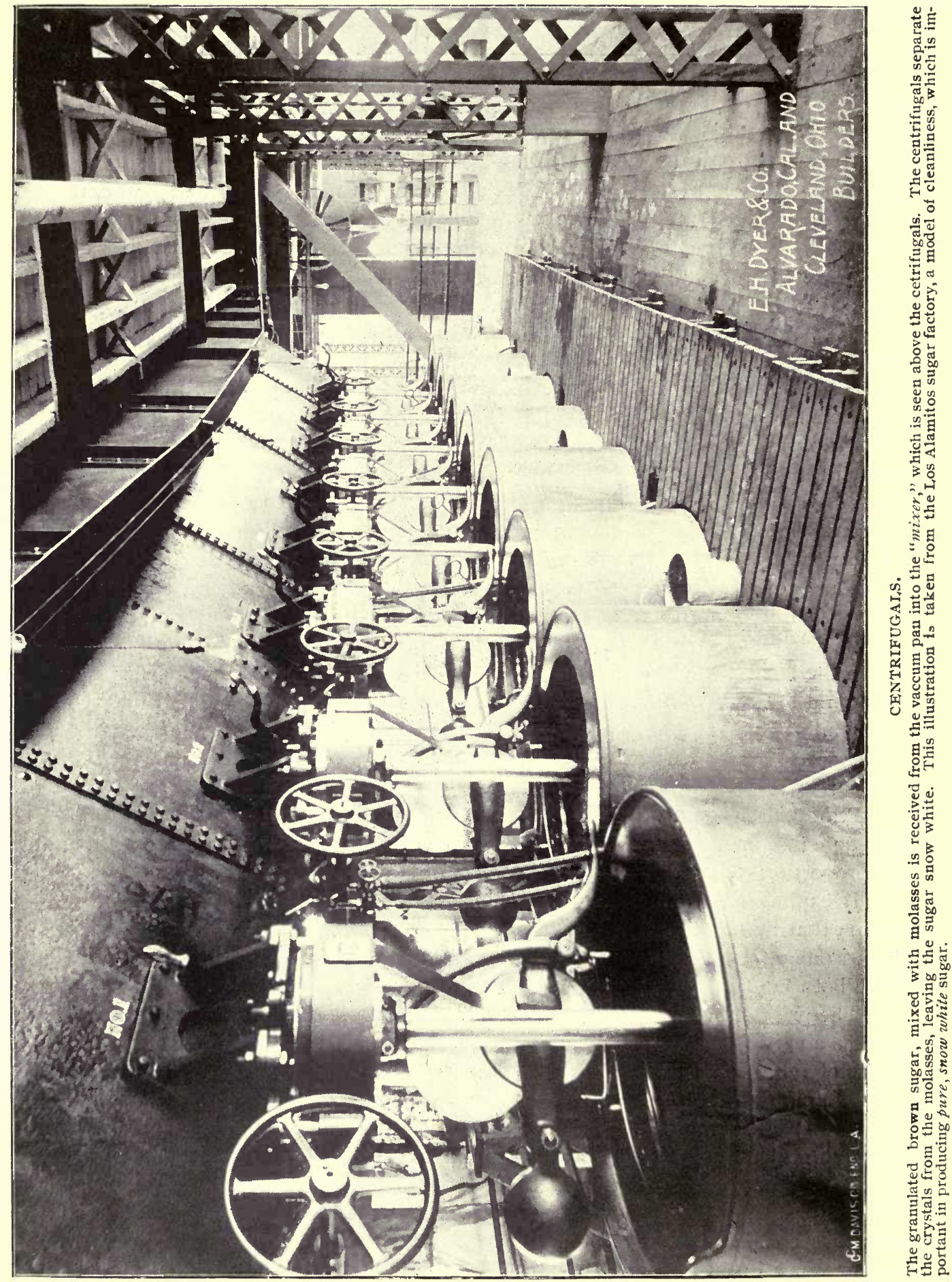


article, of which the use, like that of any other created thing, may be abused, but whose supposed unhealhtfulness has largely vanished from sight since its purchase does not tend unduly to deplete the purses of parents. The tables below, showing the consumption of sugar per capita during different periods and in different countries, may serve to allay the apprehension of those who fear that sugar will shortly become a drug in the markets of the world.

Table showing consumption of sugar in the United States, per capita, from I 867 to 1896 , inclusive :

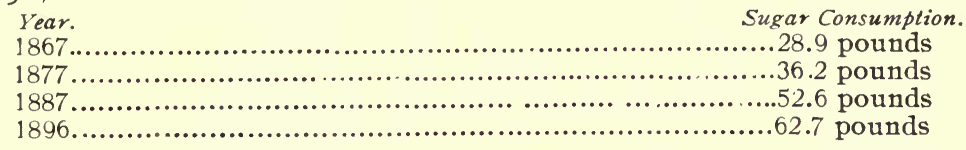

It thus appears that in thirty years covered by this table the consumption of sugar in the United States has more than doubled. In England, in a portion of the same period, the figures stand as follows: In $1876,59 \mathrm{lbs}$. ; in 1894 , 86. I lbs. In the corresponding years the consumption in the United States was only 37. I lbs. and $62.6 \mathrm{lbs}$. But while the population of England is thus ahead of the United States in the consumption of sugar, the rate of increase in consumption has been greater in the United States than any country in the world, as shown in subjoined table :

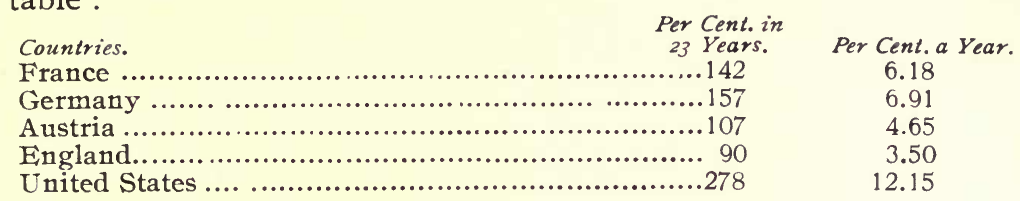

Consumption of sugar per head for various countries, I894-95 :

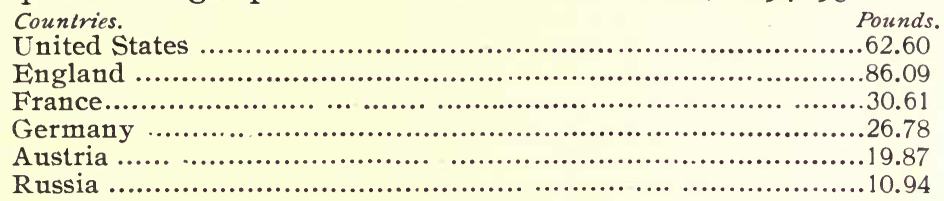

Two prominent facts are shown by the above tables. The first is that in the United States and in England the consumption of sugar increases in a more rapid ratio than the population; and similar tables show the same to be true of all European countries at least. There is probably a natural limit to the possibility of sugar consumption even by the American boy and his elders; but it is not likely that that limit will be reached within the next quarter century.

Another point shown is that if sugar consumption is not, like that of soap, to be considered the criterion of the most civilized nations, it seems certainly to follow closely the ratio of their progressiveness and commercial relations with the world at large. Thus England stands at the head and Russia at the foot of the scale. But if this is true, it inevitably follows that as social progress and intercommunication of all nations advance (and that this will be the case no sane person will question) an increase of sugar consumption will be sure to follow. The time between the present and that when the sugar consumption of all nations shall have reached its natural maximum, would seem to offer an ample margin of safety against the glutting of the market for some generations to come."

ROTATION OF BEETS AND WHEAT.-The "Pajaronian" of Watsonville publish es an interesting statement of the returns of wheat crops in Pajaro valley in r897. 


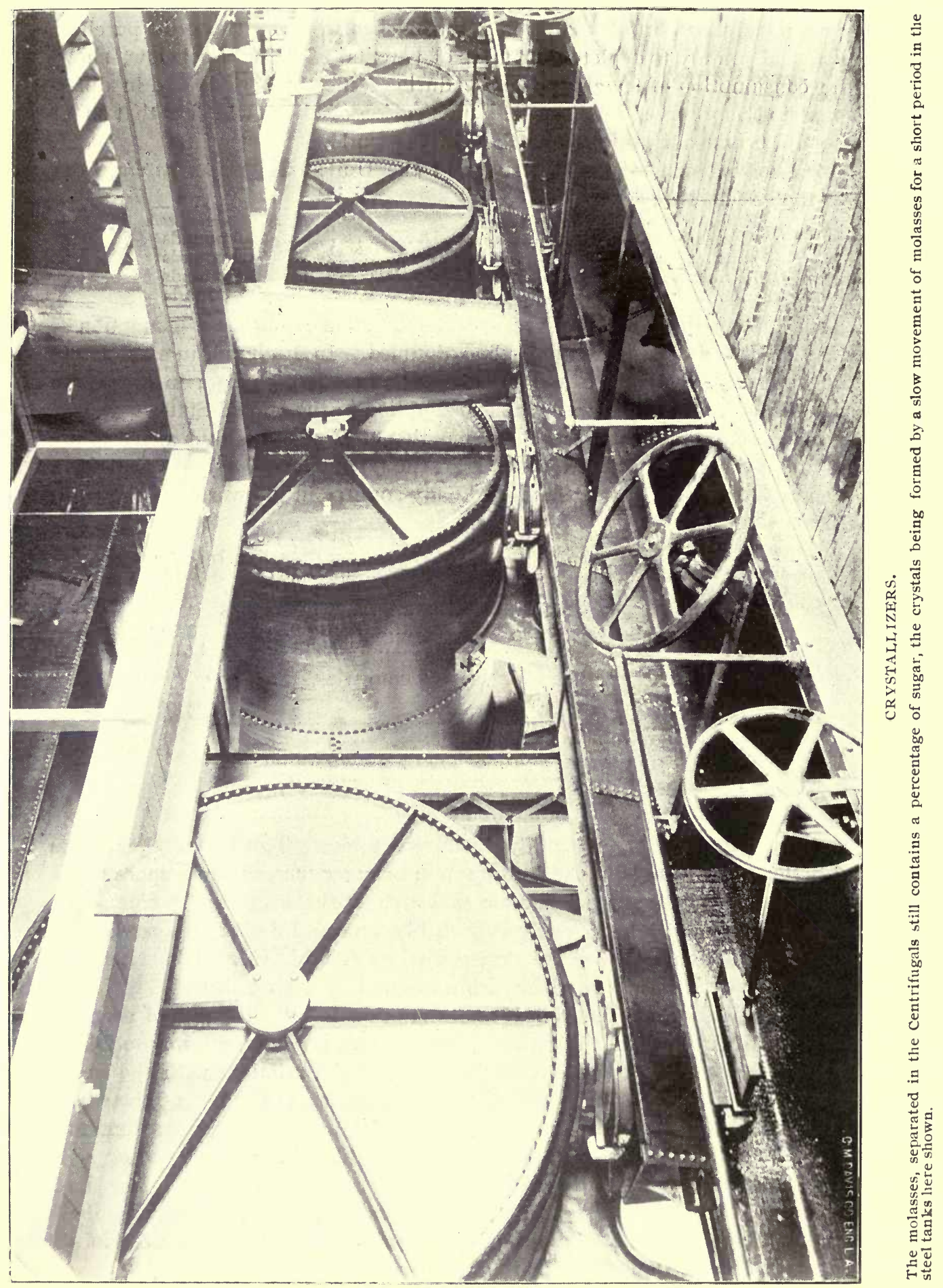


following crops of sugar beets in previous years. The statement is credited to P. W. Morse, an officer of the Watsonville sugar factory, who has supervised the field work in the Pajaro and San Benito valleys:

\begin{tabular}{|c|c|c|c|c|}
\hline NAME. & 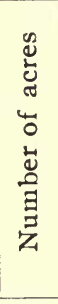 & 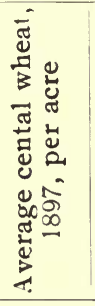 & 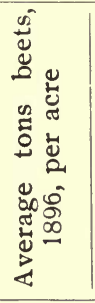 & 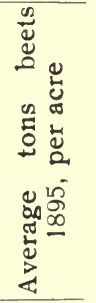 \\
\hline 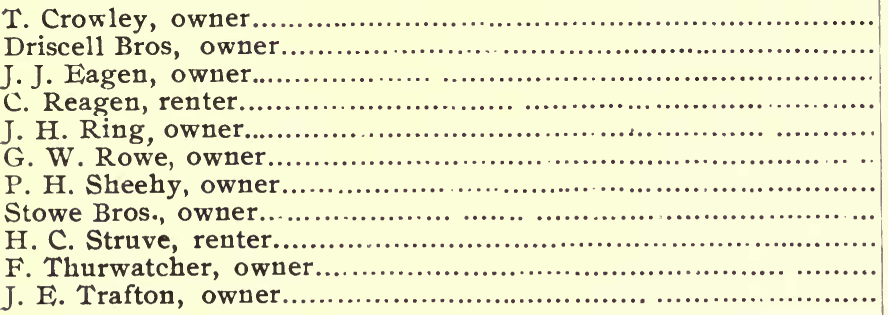 & $\begin{array}{l}20 \\
60 \\
30 \\
30 \\
16 \\
35 \\
10 \\
80 \\
29 \\
24 \\
70\end{array}$ & $\begin{array}{l}25.55 \\
27.18 \\
23.33 \\
26.40 \\
27.75 \\
27.70 \\
27.69 \\
26.94 \\
22.0 \\
25.75 \\
28.00\end{array}$ & $\begin{array}{l}20.31 \\
20.95 \\
12.89 \\
17.64 \\
1849 \\
18.79 \\
18.13 \\
13.16 \\
1363 \\
18.47 \\
2263\end{array}$ & $\begin{array}{r}1160 \\
6.91 \\
\ldots \ldots . \\
1130 \\
11.21 \\
854 \\
9.42 \\
10.88 \\
10.59 \\
12.25 \\
13.09\end{array}$ \\
\hline & 404 & 26.47 & 17.85 & 10.55 \\
\hline
\end{tabular}

Above list contains all Pajaro valley farmers who raised wheat on land farmed to beets in I896. All except J. J. Eagen, raised beets on the same land in 1895 . Average price of wheat at shipping point was $\$ 1.46 \mathrm{I} / 2$ per cental, and of beets $\$ 4$ per ton. Returns per acre (not including value of beet tops or straw) were:

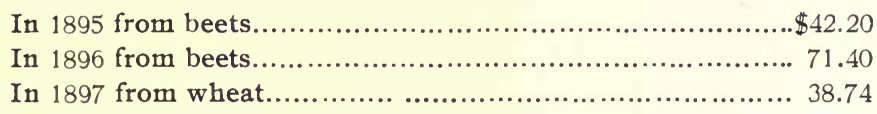

Average rental value of land was $\$$ I I.35 per acre, or 43 cents per cental. Average cost of raising wheat, $\$ 8.33$ per acre, or $3 \mathrm{~L} / 2$ cents per cental. Total cost $74 \% \frac{1}{2}$ cents per cental. Profit above rent and cost of raising was 72 cents per cental, or \$19.06 per acre, plus value of straw and stubble, which were worth on an average $\$$ I.50 per acre. Cattle were fed on the stubble and most of the straw was baled and sold to the local paper mill.

Quality of wheat raised ranked as milling and No. I shipping.

Above returns are compiled from actual figures of farmers. In all cases they have made liberal allowance for the value of their work and rental value of their land. Figures, therefore, rather overrate cost of production.

Influence, of Sugar BeEt Culture in Increasing Crop of All AgriCUlTURAI, Products. - The profit of sugar beet culture for the farmers is shown in the following experiences in Germany and A ustria-Hungary. The ten years average crop from a German farm of 625 acres in cereals was 5,736 bushels of grain before the beet culture was introduced. When the beet culture was introduced and they planted each year 125 acres with sugar beets, the average crop of grain from the remaining 500 acres was 5,730 bushels yearly. Another German farm of 625 acres in Saxony showed the following figures: Before the beet culture, the ten years average crop of grain was yearly I3,879 bushels. When each year there were planted $\mathrm{I} 35$ acres of beets, the yearly crop was $\mathrm{I} 4,365$ bushels from the re- 


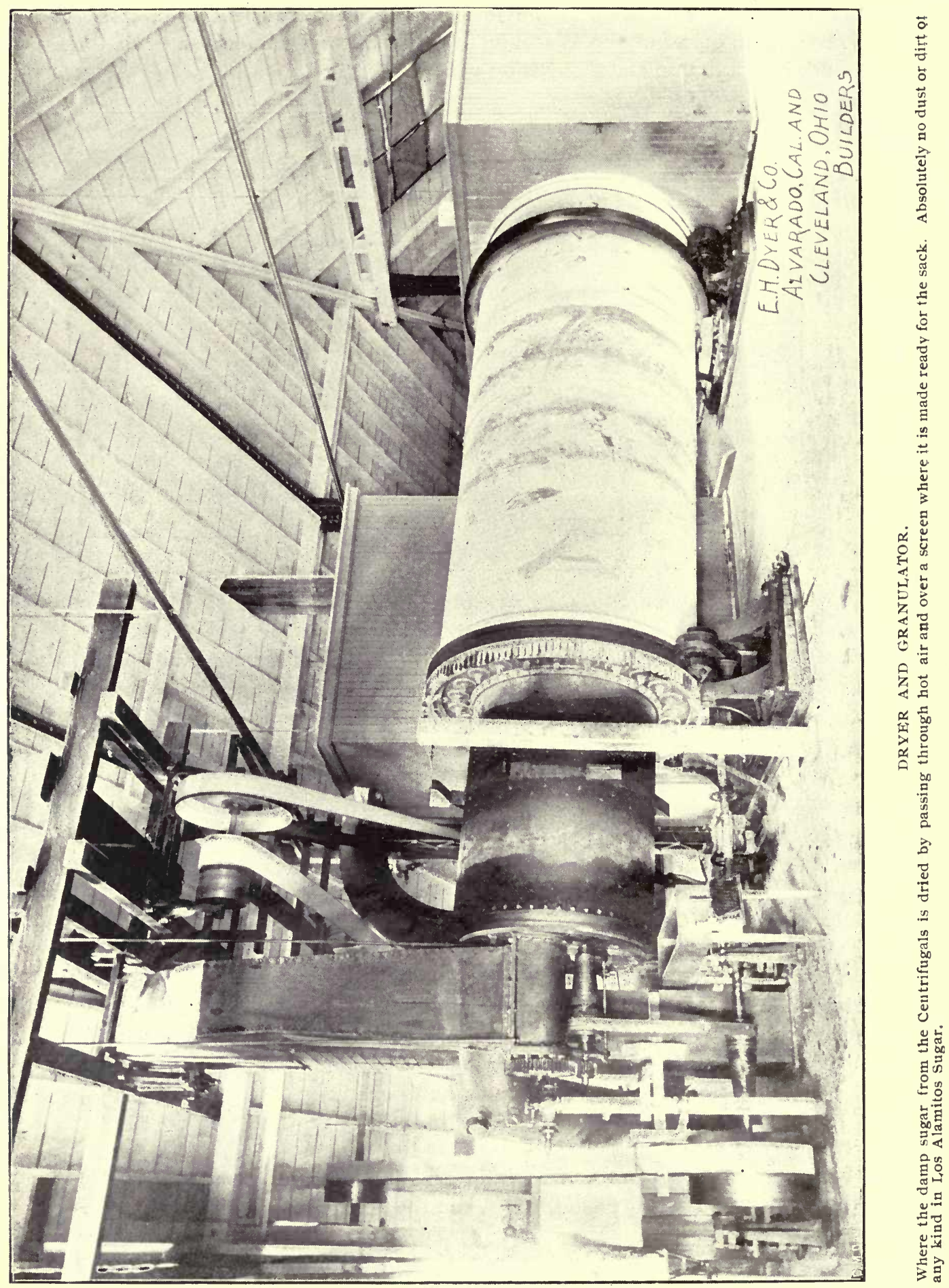


maining 490 acres, and when later there were planted 220 acres in beets, the average grain crop was 13,395 bushels yearly from the remaining 405 acres.

Thirty-five other German farms showed the following increase after they introduced beet culture, in ten years' average per acre:

Before the beet culture-

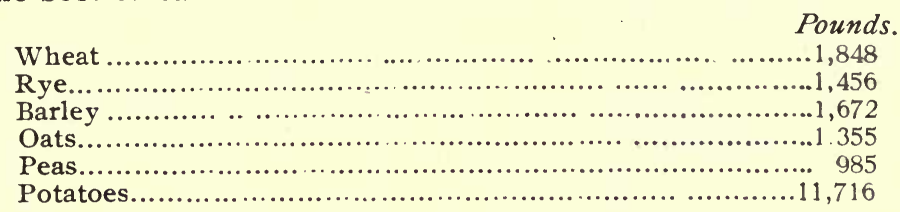

After introducing beet culture-

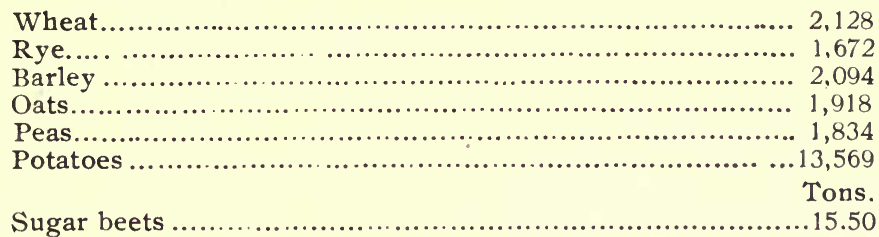

Austria-Hungary increased the crops after introducing sugar beets and deep culture, as follows: In winter crops, I 2 to 5 per cent; in corn, ro to 30 per cent; in tobacco, 20 to 24 per cent, and in beets 30 per cent.

There was an average increase in all crops of about $2 \mathrm{I}$ per cent in Germany and Austria-Hungary, in consequence of sugar beet culture.

By-PRODUCTS.--The by-products of the sugar factory consist of lime-cake, waste molasses and pulp. The latter is in proportion, 46 per cent. of the raw product. As a food for dairy cows, for beef cattle or for sheep, it has no superior. It is the cheapest food obtainable at $\$ \mathrm{I}$.oo per ton at the factory. When carefully housed in well constructed silos, it has no competitor as a food for the animals named. It is not suitable for hogs. They will grow, but not fatten.

LetTer From a DAIRYMan in Riverside to a DaIryman in Los AngeLES. - "DEAR SIR : Yours of the 2oth at hand, and in reply will say that my experience in feeding beet pulp is as follows:

First: I find it best not to feed it until it is at least ten days old, and the older the better. I was feeding ninety cows, and when I commenced feeding, all my cows with the exception of nine ate it the first day; all of them ate it the second day. For three or four days they dropped in their milk, after that they went up in their milk to more than they gave on any other feed, and the quality was increased. The week before I commenced feeding pulp I tested my milk, and it took $53 / 4$ gallons of $\mathrm{m}_{\mathrm{i}} \mathrm{lk}$ to make $\mathrm{I}$ gallon of cream, and $\mathrm{I} 2$ gallons of cream to make ro full rolls of butter. After feeding the pulp two weeks I again tested the milk, and five gallons of milk made I gallon of cream, and I 3 gallons of creain made 2 full rolls of butter.

Second. I feed my 90 cows 45 pounds each of pulp at a feed with six pounds of hay. I put the hay in the mangers and the pulp on top ; or to put it exact, I feed four tons of pulp per day and one-half ton of hay.

Third. The pulp costs me laid down at my dairy, $\$ 2.25$ per ton.

Fourth. It is cheaper at $\$ 2.50$ per ton than hay at $\$$ IO per ton, and than bran at $\$ 20$. 


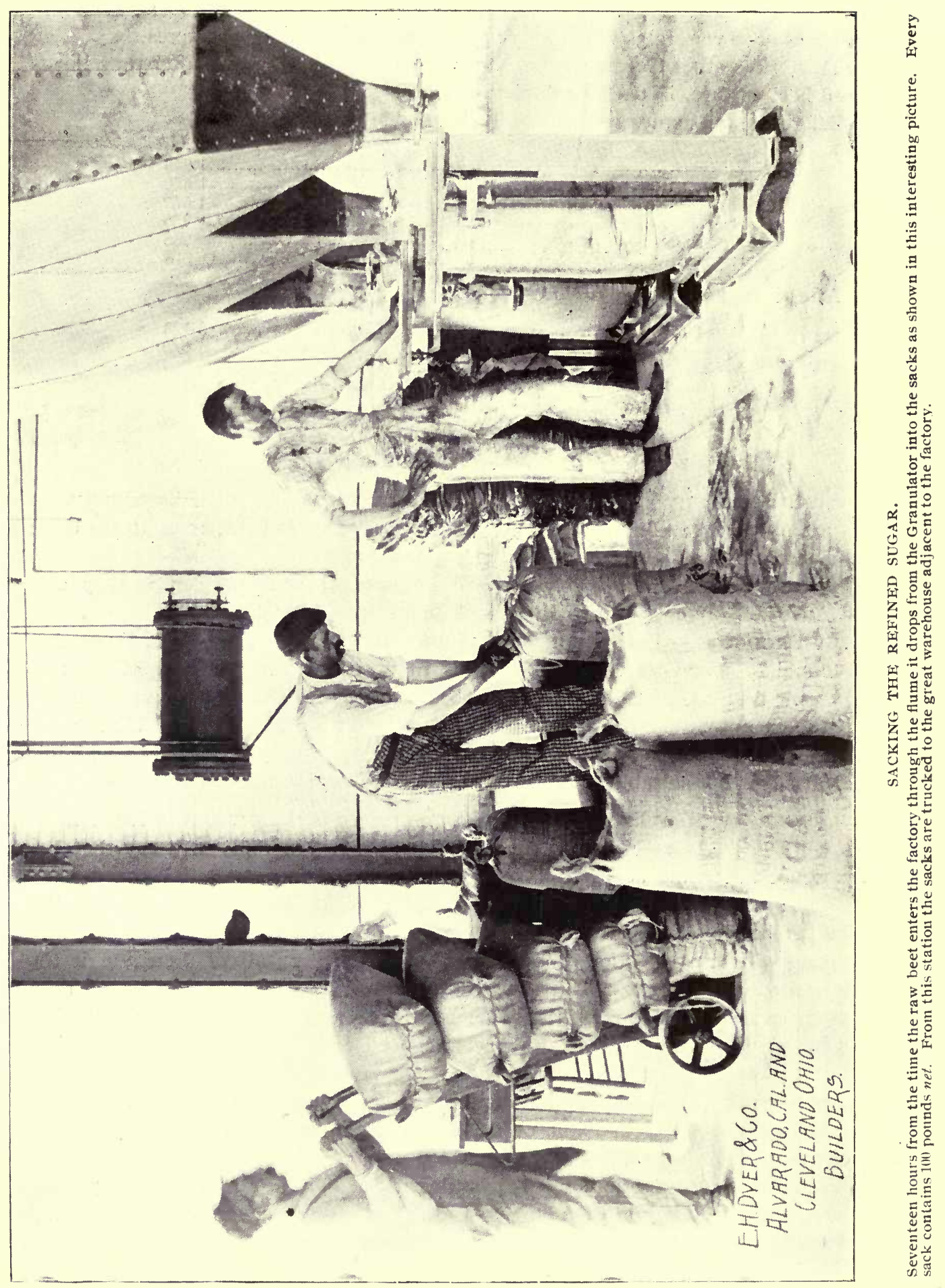


I weigh all my feed and weigh all my milk, and can get more pounds of milk feeding pulp than any other feed I have ever fed and for less money. I feed my cows the year round; they never are turned out to pasture. My aim is to feed my cows all they will eat up clean, and I find it pays me to do it."

The CosT of MAKIng a CROP is an important one, but it seems manifestly unfair to charge up every item of labor, unless it is done with other farm crops in the way of comparison. The amount the farmer pays--seed and labor-should be charged; but his own labor is a legitimate part of the profits. In ten acres the cost should be :

Seed

Help.

Total

Results : 120 tons @ $\$ 4$ per ton.

Less expense.

Profits

$\$ 41000$

FIRST INSTANCE. ILLUSTRATION, CHARGING EVERY ITEM OF LABOR.

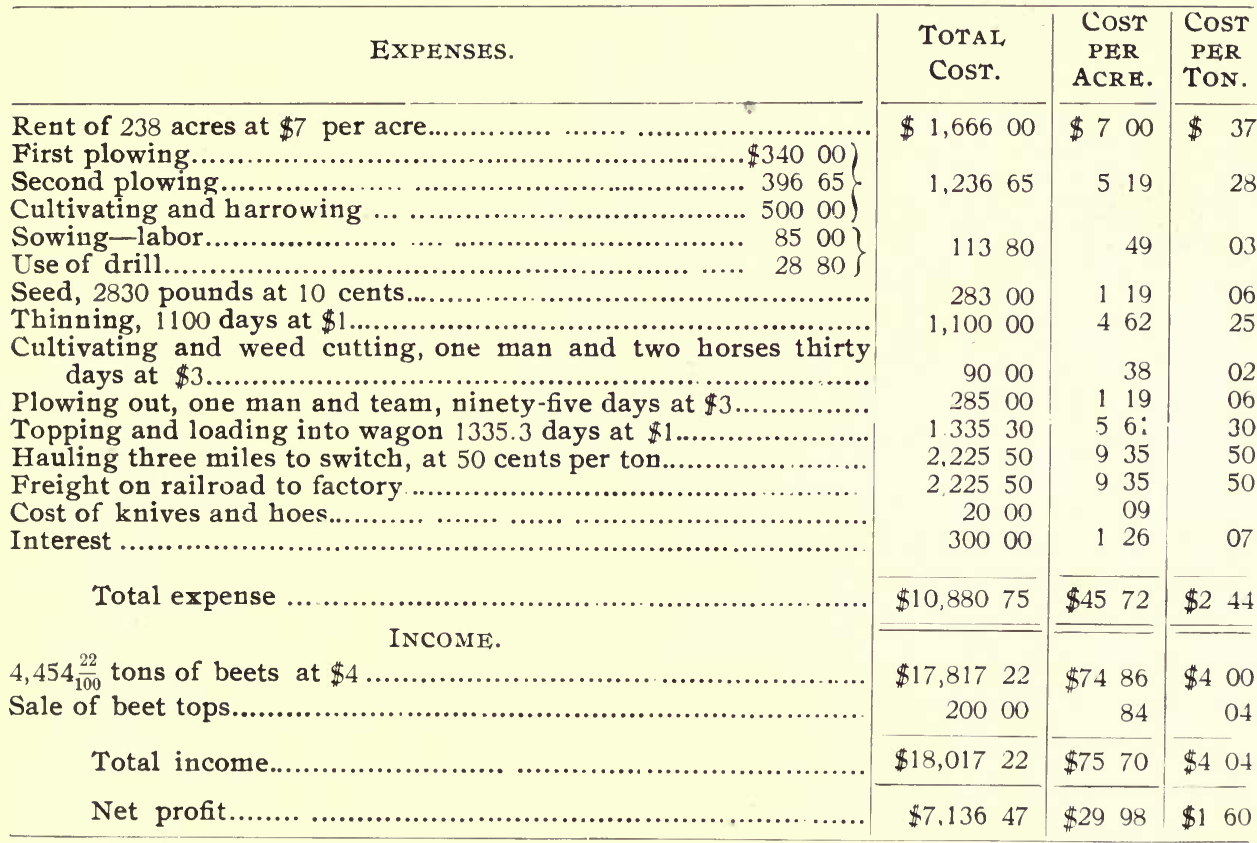




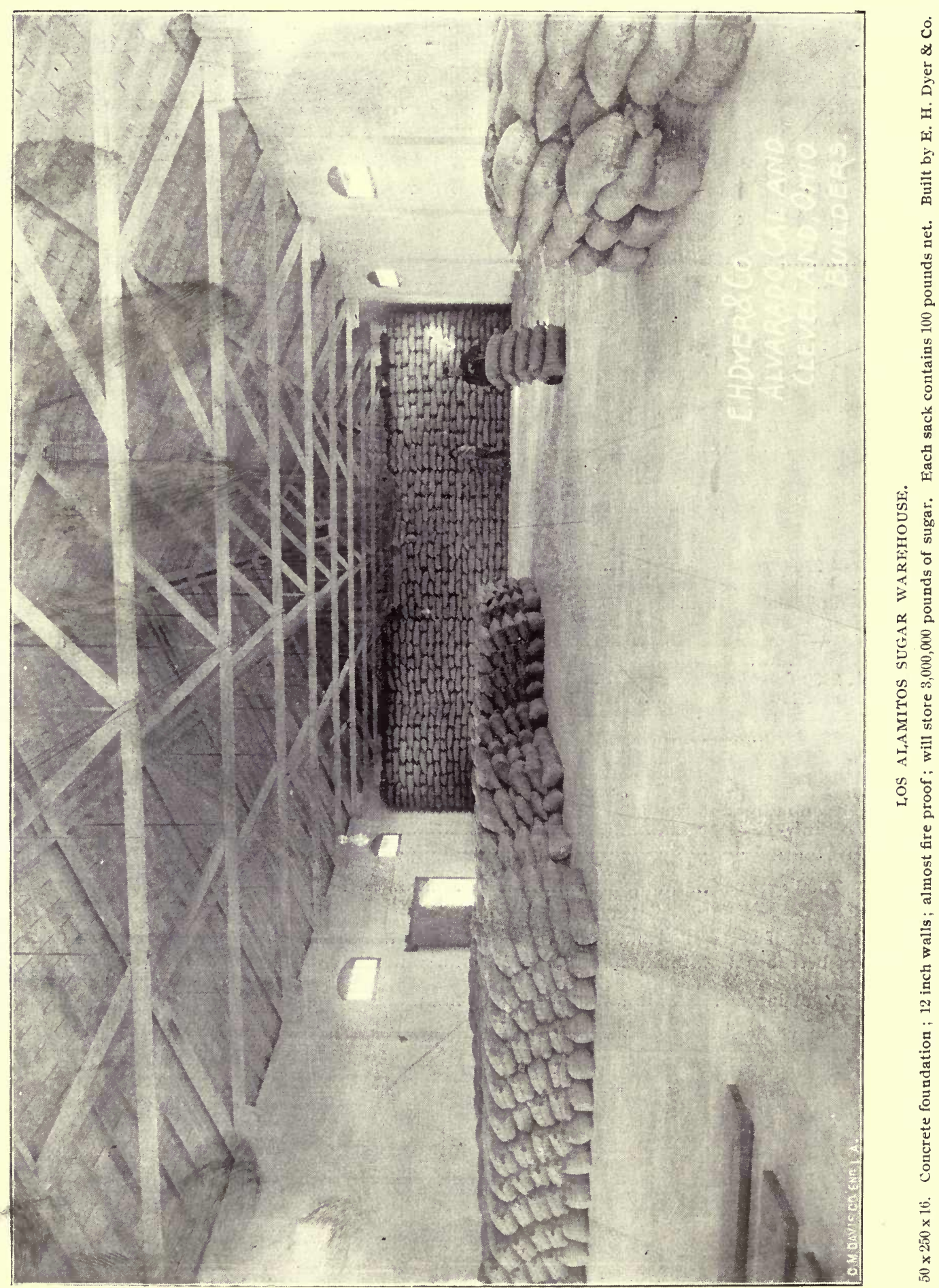


SECOND INSTANCE.

COST PER ACRE.

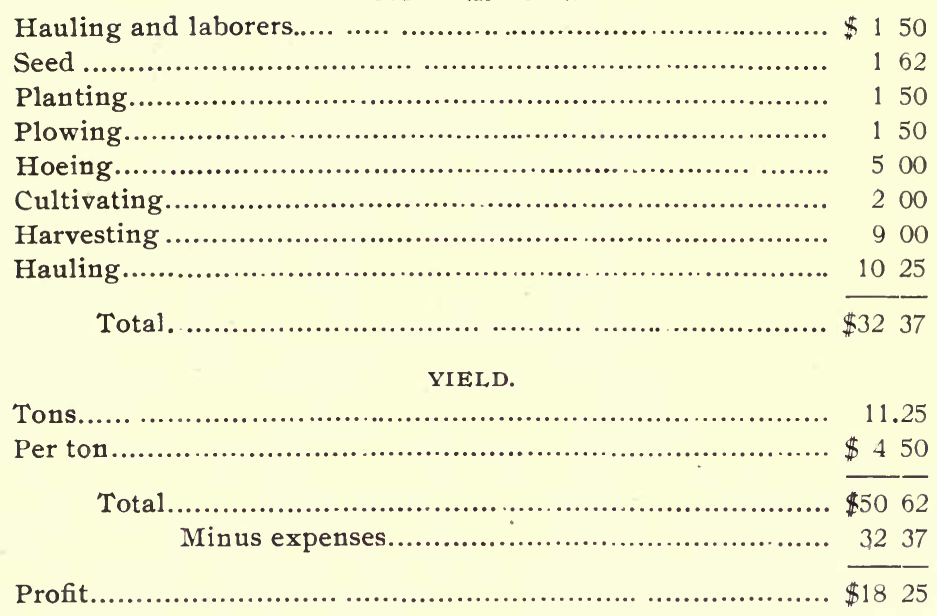

RECORD OF A CROP OFF 40 ACRES THAT PAID \$3O PER ACRE NET PROFIT IN NEBRASKA.

EXPENSES.

Seed.

Hand work at $\$ 13$ per acre.

Topping beets at $\$ 3$ per acre

Freight at $80 \mathrm{c}$ per ton.

Extra hand labor.

Total

Balance for team work, use of land and net profit

53840
PROCEEDS.

$\$ 10700 \quad 5772 / 3$ tons at $\$ 5 \ldots \ldots \ldots \ldots \ldots \ldots \ldots \ldots \ldots . \$ 288833$

$48000 \quad 461 / 3$ tons at $\$ 2.50 \ldots \ldots \ldots \ldots \ldots \ldots \ldots \ldots . \ldots \ldots \ldots . \ldots \ldots$

12000 siloed................................ $77 \quad 34$

$15400 \quad$ Total............................ \$3081 50

Less expense ........................ 139940

$\$ 168210$

The above are all actual experiences of beet farmers.

In Storing Beets when Frost Compels Harvesting at a Stated PerIOD, there are various methods of constructing silos. The entire subject is an almost untried field, and we will not advise, except in cases where we know the temperature to be expected, and this must be done by correspondence. $\mathrm{Mr}$. Cutler of the Lehi factory writes:

New METHOD of STORING BeETS.-When this factory was first built, we erected five frost-proof beet sheds, which were made of lumber, walls lined with straw. They are five hundred feet long and twenty-six feet wide, constructed with a sluice in the center, so that the heets can be shoveled into it and brought to the factory by water, which is not only economy but it gives them a thorough washing.

We have discovered since then, that frost is something we are not afraid of, providing that our beets are brought here in a perfect state. We have erected since then several platforms, one of which has sides to it, but the top is left entirely open. It is five hundred feet long by thirty-four feet wide, and will hold fully 3000 tons of beets. We also have other platforms with a sluice in the center, but without any sides, and we use a movable railroad track-as fast as the beets are unloaded, the track is moved farther out, until we have an enormous pile resting on the plank or platform as above described. 


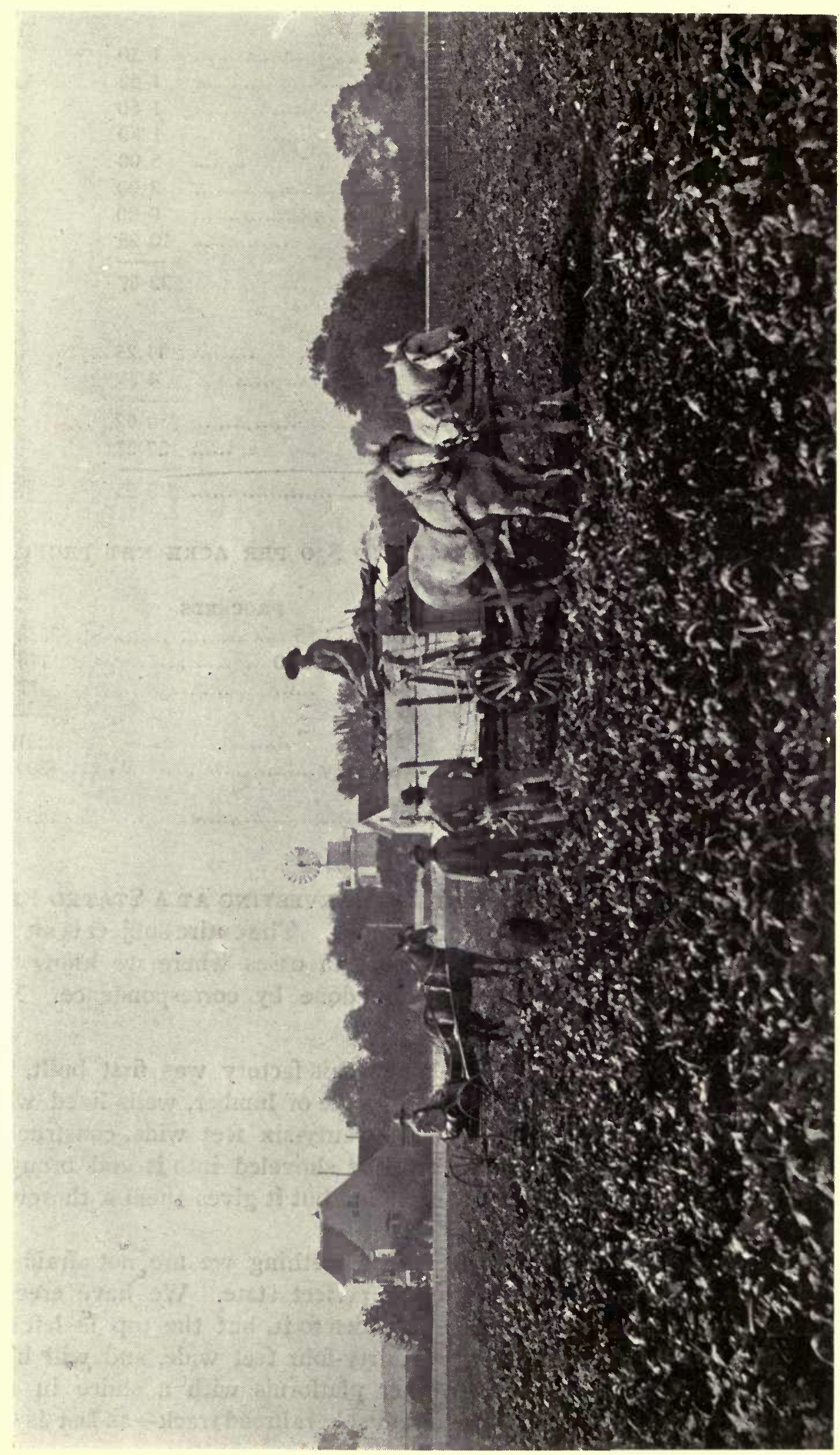

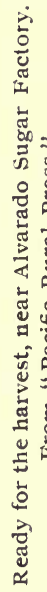


This year we are trying some further storage, and have just finished two sluices which have been constructed and inserted on the bare ground, and we expect to store 6000 or 7000 tons of beets in that manner. When the frost comes, it freezes over the surface of the stored beets to a depth of two or three beets, but there is enough vegetable heat generated in the large pile to keep the beets in good condition, and we have never lost a beet yet through frost-we are more afraid of the sun's rays than we are of frost.

WHAT CAN BE DONE WITH GREEN BEETS AND THOSE OF LOW PURITY, AND CONSEQUENTLY UNFIT FOR FACTORY USE.

Sugar BeEts as CatTle Food.-C. S. Plum, director of the Purdue, Indiana, experiment station, has very commendatory words for the sugar beets in a recent report. While the beets have not more than one-sixth the muscle-forming food of clover hay, yet they have important use in abetting digestion. He says that the practice speaks loudly in favor of beets in winter, combined with dry feed, and that sugar beets take the lead. "They contain more nutriment than mangels, carrots, rutabagas or common turnips." Their sugar, he says, adds to their palatability. For sheep and milch cows they rank high. They regulate the bowels and give an elegant gloss to the skin. At the late dairymen's association at Compton, more of the feeders favored stock than sugar beets. Prof. Plum rightly states that chemical analysis does not tell the full value of such food. He says that they rank very high in Great Britain, and are valued at from $\$ 2$ to $\$ 2.50$ per ton in the United States. He says that the feeding experiments at the Purdue station have been very favorable to sugar beets. While in Ohio a comparison was made by feeding silage and field beets to dairy cattle. The beets caused the best gains in weight of cows, size of milk flow and production of butter fats. Sugar beets, unlike turnips, never give any taint or unwholesome flavor to milk or any of its products.

Prof. Plum recommends slicing and feeding about fifty pounds per day, with a sufficient amount of dry feed. The pulp from the sugar factories is very valuable for dairy stock. Cows eat about Ioo pounds each per day with about 5 pounds of dry food. The California experiment station finds that the pulp contains nearly as much of the proteids as does corn silage, and that the feeding value is $\$ 2.02$ per ton, while corn silage is worth $\$ 3.22$ per ton. But pulp can be put into the silo with entire success, and with the great number of factories being built, beet pulp as silage must take a prominent place as food for the dairy.

NOTE.-The quantity of beet pulp consumed per head of cattle, is nearer 75 pounds than 100.-ED.

RELIABLE BEET SEED. - Sugar beet seed from reliable sources can be ordered from Meyer \& Raapke, Omaha, Neb., agents for Klein Wanzleben original. An excellent beet, adapted to the average soil and climate in the United States.

Vilmorin-Andrieux \& Company, Paris, France. An exceedingly rich beet.

Deppe Brothers-Earnest Rolker \& Son, agents, New York City, N. Y. This well known variety has been very successful in the West.

There are other reliable seedsmen in Europe, whose seeds we have not yet tested in large quantities for factory supply. 


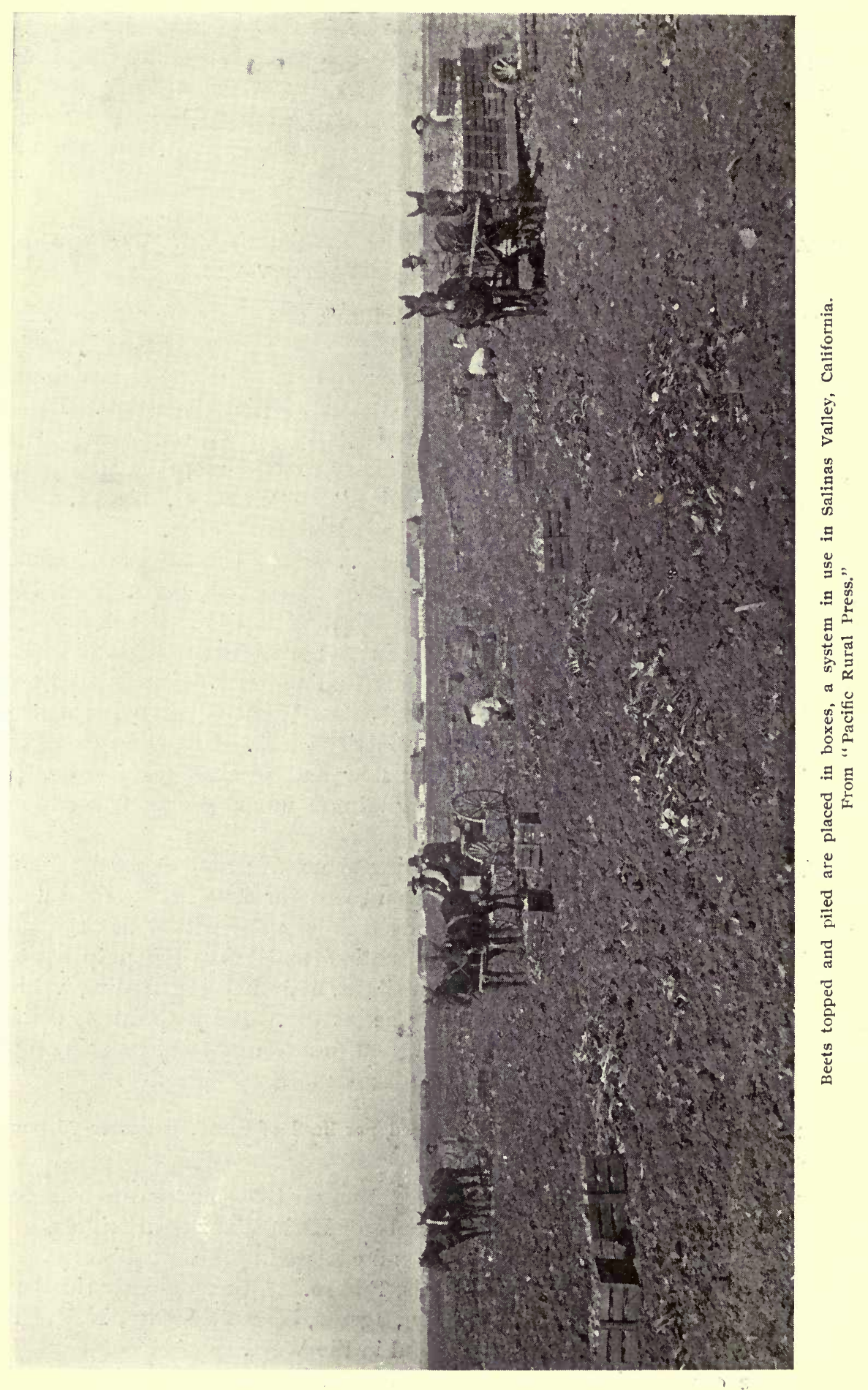


ANALYSIS OF LIME CAKE FROM FILTER PRESS.-A BY-PRODUC'T.

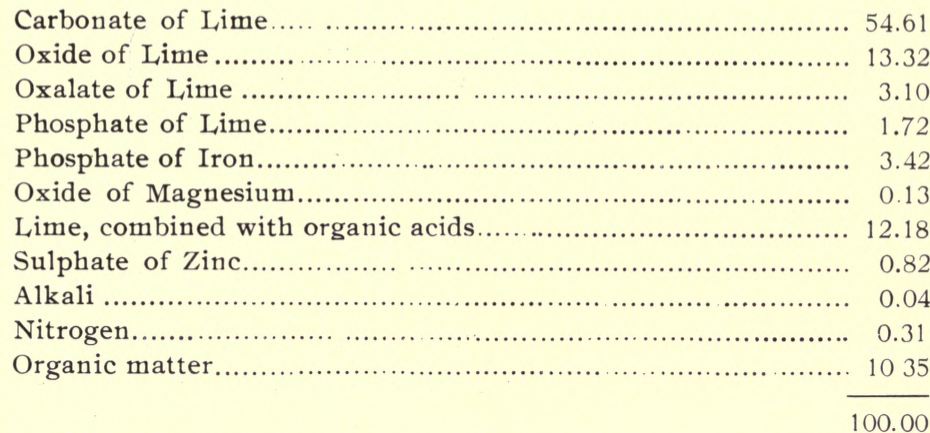

AMERICA LEADS THE WORLD.

It is the writer's intense belief that America is for Americans ; whatever they undertake, they do well; the ultimate destiny of the United States is so far beyond the conception of the careless thinker, that pleasure has been taken in proving that so far as making the most intricate, the most perfectly adjusted machinery demanded by an industry more exacting than almost any other in the world, we lead rather than follow the bright chemists and mechanical engineers of Europe.

A visit to any of the German or French made plants in the sugar houses of the United States, and then to the Lehi and Los Alamitos factories will convince any person of business experience that, not only in results, but in arrangement of the various parts of the work, special study has been made with a view to economy of labor; a matter of little importance to European corporations where labor is so poorly paid ; but of great moment to us, where the commonest labor receives $\$ \mathrm{I} .75$ per day.

In fact, study American machinery as you choose, her vehicles, her mining machines, her agricultural implements, or her technical works in steel, copper or sugar, and we lead the world. 


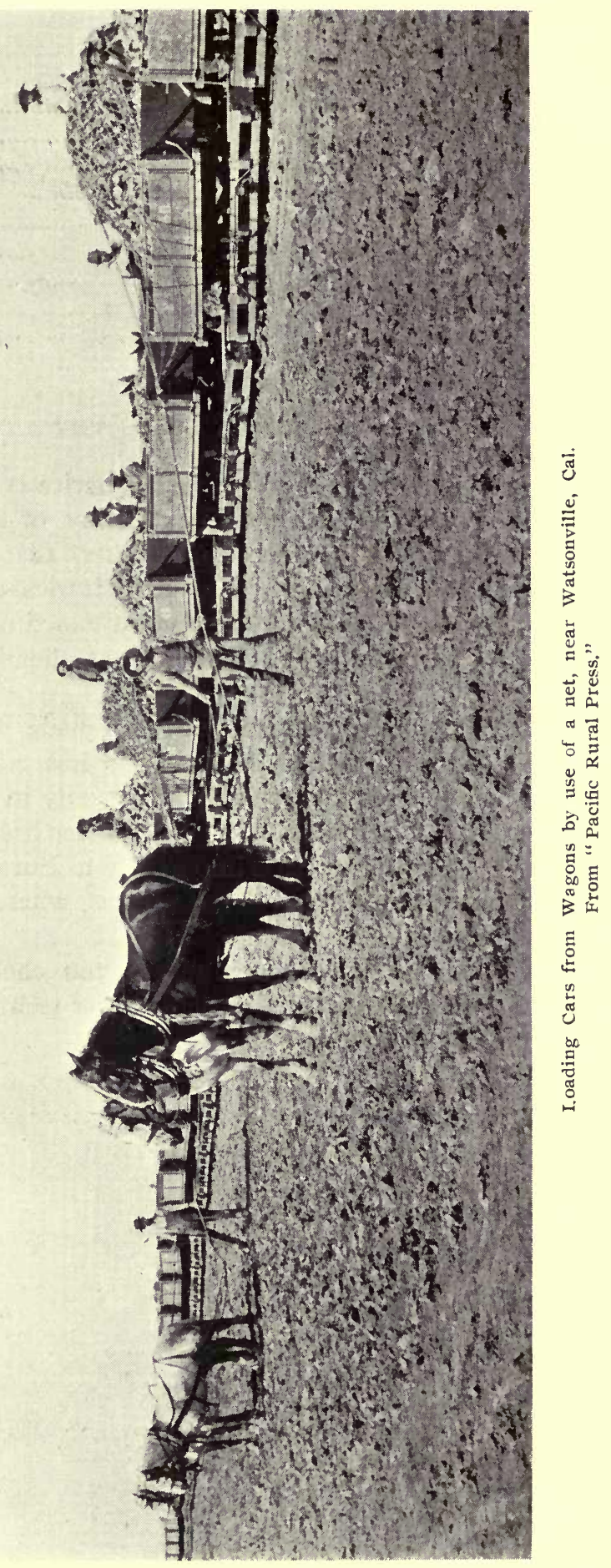




\title{
American Beet Sugar Factories
}

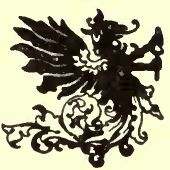

\author{
"The Location" \\ "The Machinery" \\ "The Technical Management"
}

\section{ALL IMPORTANT MATTERS ...}

That demand the serious consideration of those who intend to build Beet Sugar Factories.

The hard common sense that has so well served the successful American business man in other enterprises, is not alone sufficient to decide the questions involved in the selection of a proper location, the equipment and construction of a beet sugar plant.

The site being chosen, the building must be adapted to the demands made by the machinery; the machinery must be of the latest and most approved type.

The technical management must be up-to-date and capable of producing the best possible results, at the least expense. The sugar factory being a vast laboratory, only chemists perfectly acquainted with the specific branches of chemistry involved in the operations of a sugar factory can be profitably engaged.

The machinery must be constructed so as to show highest efficiency with economy of labor, efficiency first; the object being to secure the highest extraction at reasonable expense.

In selection of site for sugar works important physical conditions are to be considered, which are always apparent to the experienced, and have much to do with net results.

All the foregoing features are noticeable in the successful plants erected by the Pioneer American Beet Sugar Construction Company.

\section{E. H. DYER \& CO. \\ $-\mathrm{OF}-$}

ALVARADO, CALIFORNIA, and CLEVELAND, OHIO,

Who have had 20 years experience in the manufacture of beet sugar (alway's successful), and still largely interested in the most profitable beet sugar farms and sugar factories in the United States, with

\section{Facilities Unsurpassed by no Firm or Country}

In the Manufacture of Complete Machinery

for the most modern sugar houses, offer their services to the American people as Builders, Technical Managers and Agricultural Experts in the development of the great industry, and will contract to build beet sugar houses of latest type, guarantee their successful operation, and furnish skilled men to run them.

\section{ADdRESS: E. H. DYER \& COMPANY}

Cleveland, Ohio

Or, Alvarado, California

Factories Built by E. H. Dyer \& Co., to whom they refer: Utah Sugar Company, Lehi, Utah.

Los Alamitos Sugar Company, Los Alamitos, California.

Now Building $\left\{\begin{array}{l}\text { Ogden Sugar Company, Ogden, Utah. } \\ \text { La Grande Sugar Company, La Grande, Oregon. }\end{array}\right.$ 

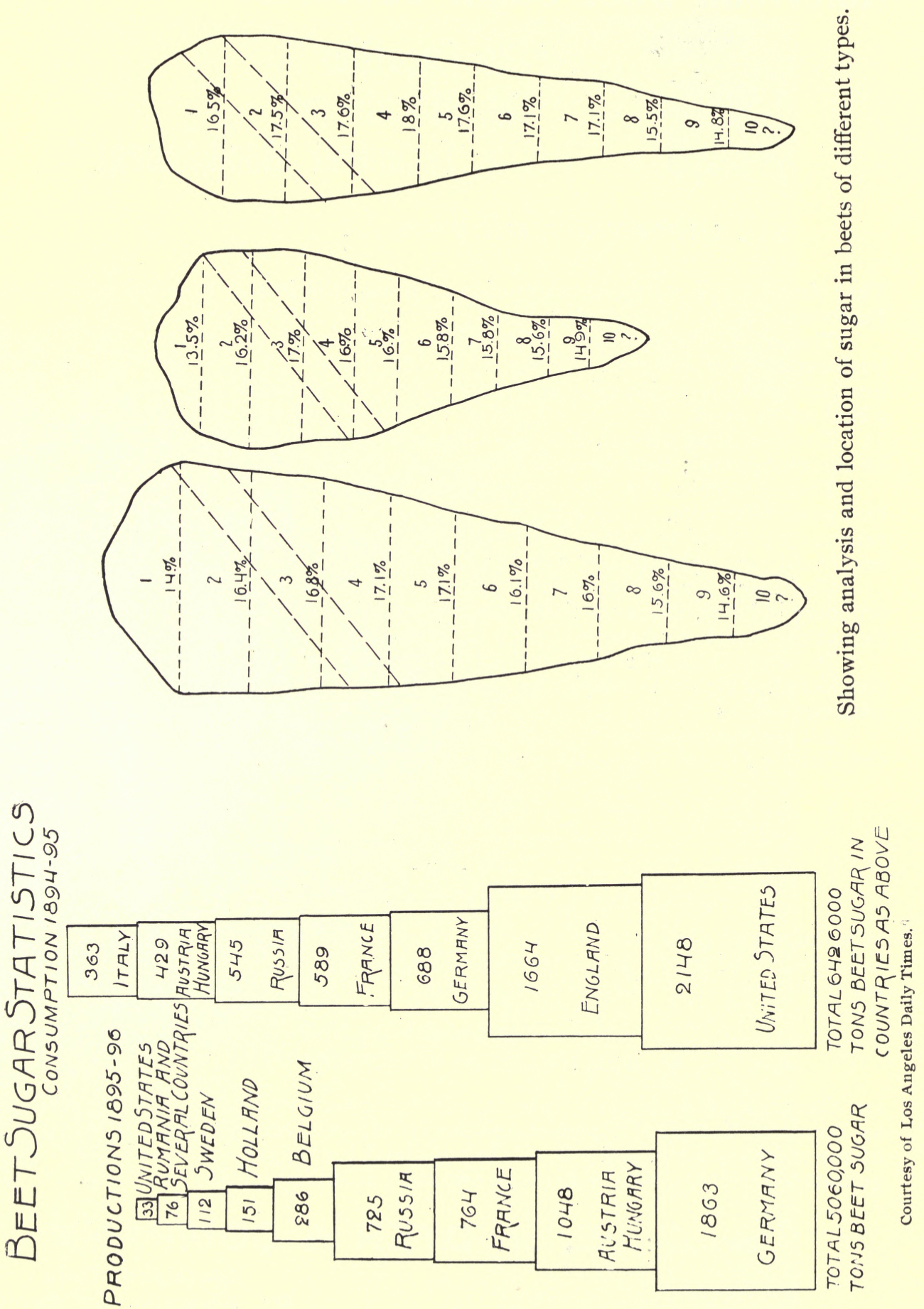


\section{Use Petroleum and....}

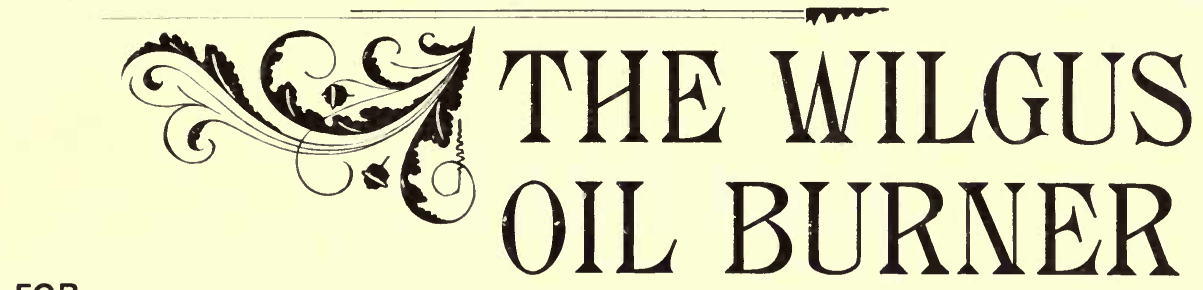

FOR ....

\section{ECONOMY AND EFFICIENCY}

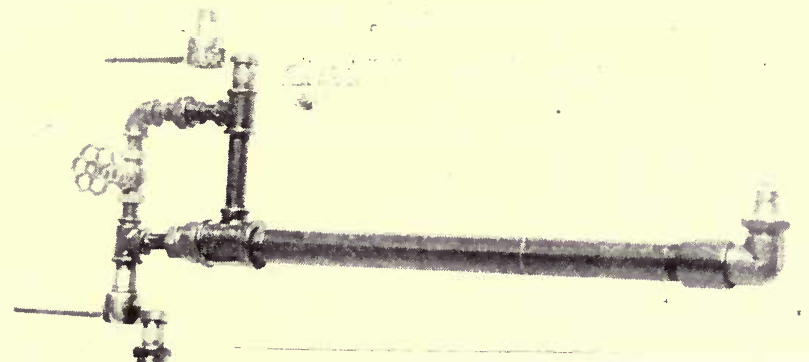

The great success that has attended the use of Wilgus Oil Burner in the Beet Sugar factories at

\section{CHINO \\ LOS ALAMITOS and CROCKETT}

$$
\text { .... in }
$$

\section{CALIFORNIA}

And by ALL the STREET RAILWAYS, Electric Light and Power Companies, Hotels and Breweries in Los Angeles, and by many manufacturing plants and power companies in San Francisco and elsewhere, prove conclusively that no fuel can compare with Petroleum, at a reasonable price, if the Wilgus Burner be used.

The burner requires $3.07 \%$ of the water evaporated in the boiler to vaporize the oil and produce perfect combustion. The heat is all retained in the fire box and is not blown to the back end of the boiler and up the smoke stack; requires no bridge wall, and operates with very little oil pressure. The fire can be reduced to $90 \%$ below the maximum capacity of the burners ; will burn oil of 12 to I 4 degrees gravity, with an asphalt base, or higher gravity with paraffine base, equally as well. Has patent quick adjusting unions to remove burner from beneath the boiler and replace without allowing steam to run down, and in water tube boilers the flame does not come in contact with the boiler but directs the entire energy of the flame to the tubes with the consequent result of high efficiency and greatest possible economy.

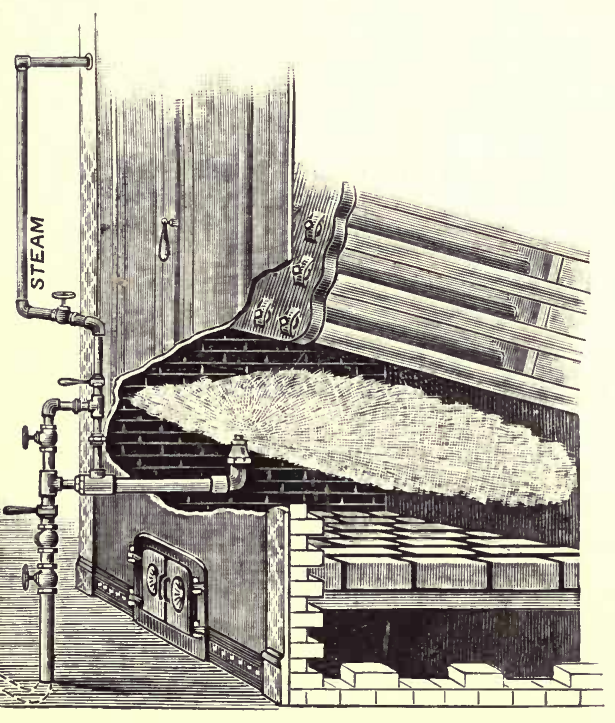

REFERENCES ...

Los Alamitos Beet Sugar Co.

Los Angeles Railway Co.

Pasadena and Pacific Railway

Los Angeles Traction Co.

The Los Angeles Ice and Cold Storage Co.

Maier \& Zobelein Brewery

Cudahy Packing Co. and any user of my burner.
MANUFACTURED AND SOLD BY...

D. C. WILGUS

126 E. Third St., Los Angeles, Cal. 


\section{SOUTHERN PACIFIC SYSTEM}

$\mathrm{OF}=$

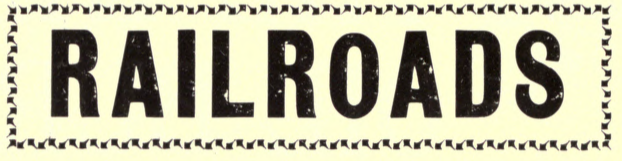

THE GREATEST IN THE WEST

REACHING ALL THE IMPORTANT CITIES

WEST

Portland, Oregon

Ogden, Utah

New Orleans, Louisiana

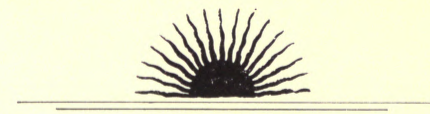

\section{The "Sunset Roule" from ... PORtLAND, oregon}
Through ...... . SAN FRANCISC0
LOS ANGELES
EL PASO and SAN ANTONI0, Texas
To . . . . . NEW ORLEANS

Opens up the cream of the Pacific Coast. Its fertile valleys, the rich mineral regions, the vast areas of magnificent forests are only reached

by the Southern Pacific Railway.

\section{THE BEET SUGAR FACTORIES}

$\begin{array}{ll}\text { At...... CHINO } & \text { LOS ALAMITOS } \\ \text { WATSONVILLE } & \text { SALINAS VALLEY } \\ \text { HUENEME and } & \text { ALVARADO } \\ \text { Six in all } * * * & \end{array}$

ARE ONLY REACHED BY THE SOUTHERN PACIFIC LINES

Sugar factories are never located on bad lands, and it is significant that all of them are situated upon the Southern Pacific Company's railways. Route your freight and purchase your tickets via The Southern Pacific; Shasta, Ogden or Sunset Route, and you will make no mistake.

J. C. STUBBS

Second Vice-Pres't, San Francisco 


$+i$

KINGSLEY-BARNES G NEUNER CO.

PAINTERS, ENGAAVEAS AND BINDENS

LOS ANGELES, CALIFOANIA
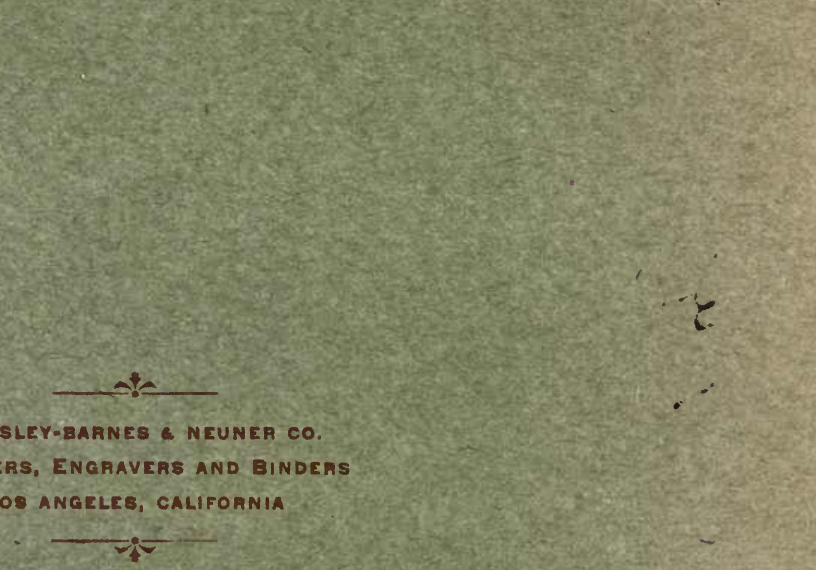

$\sec ^{2} x^{2} x^{2}$

Sot

tis.

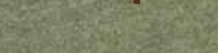






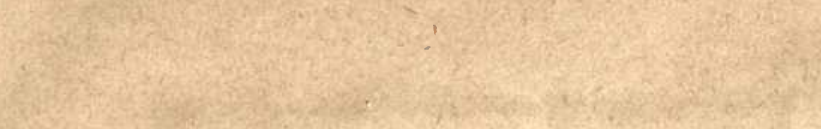

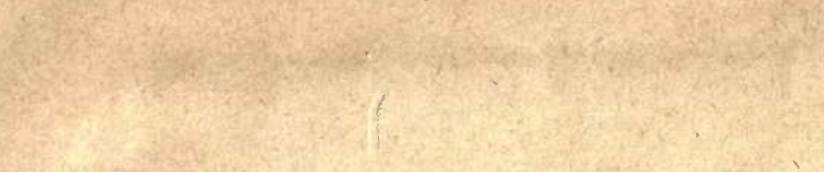

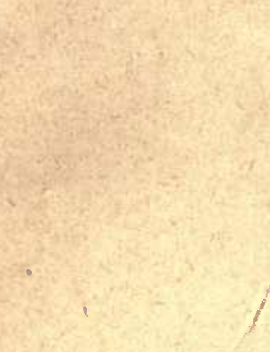


THIS BOOK IS DUE ON THE LAST DATE STAMPED BELOW

AN INITIAL FINE OF 25 CENTS

WILL BE ASSESSED FOR FAILURE TO RETURN THIS BOOK ON THE DATE DUE. THE PENALTY WILL INCREASE TO 50 CENTS ON THE FOURTH DAY AND TO \$1.00 ON THE SEVENTH DAY OVERDUE.

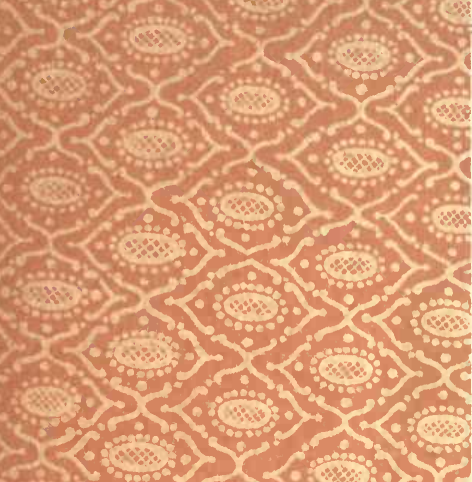

SEP 131932 JUN 41960

LIBRARY USE

AUG 151952

13 Niar 5875
nxan iso

hing :?:?

Hor'60WR

REC'D LD

APR 221960

30 May' $60 W W^{\prime}$

LD 21-20m-6,'32 


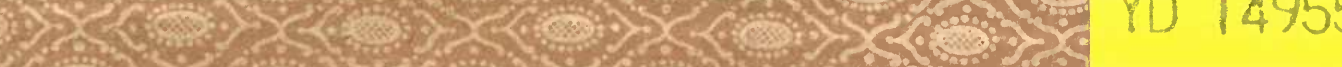

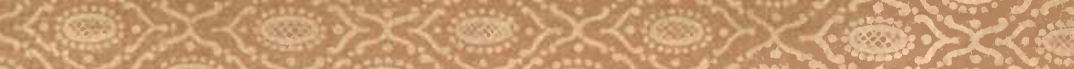

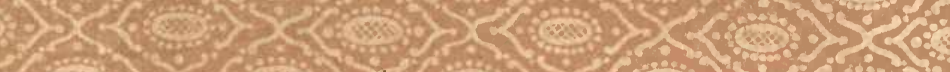

38

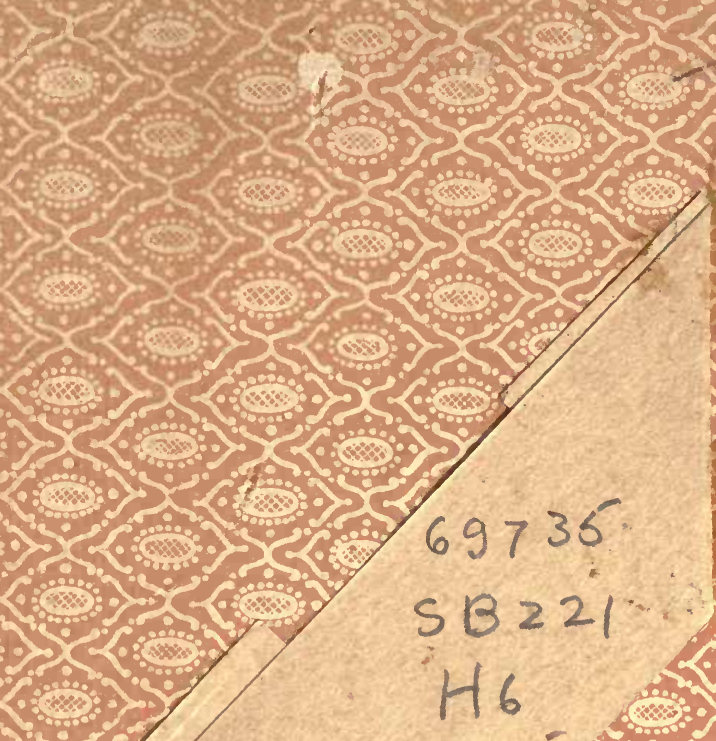

intiog

$\rightarrow 20$ h

sis ?

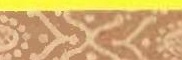

$\left.x_{0}\right)^{2}$

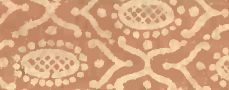

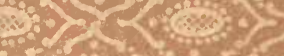

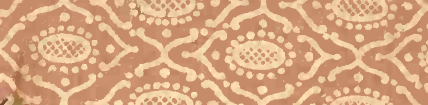

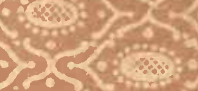

ons 5

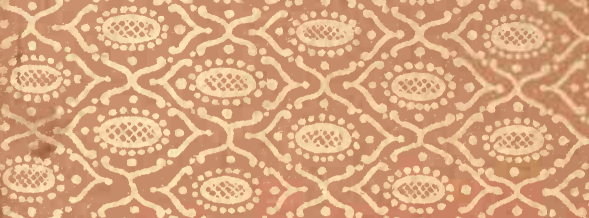

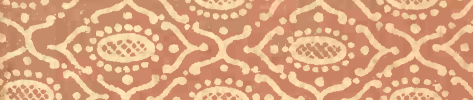

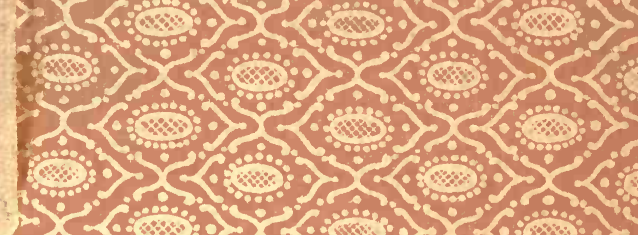
15

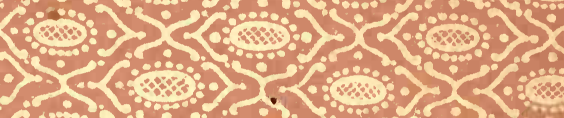

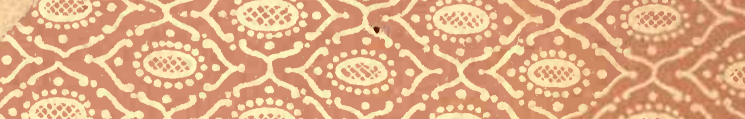

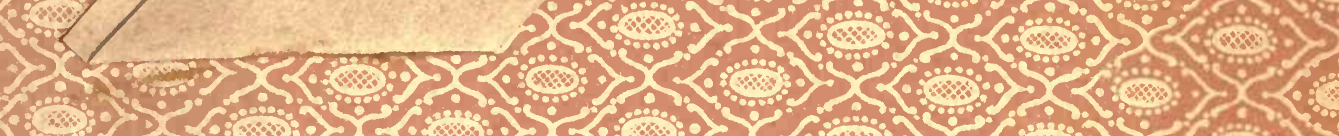

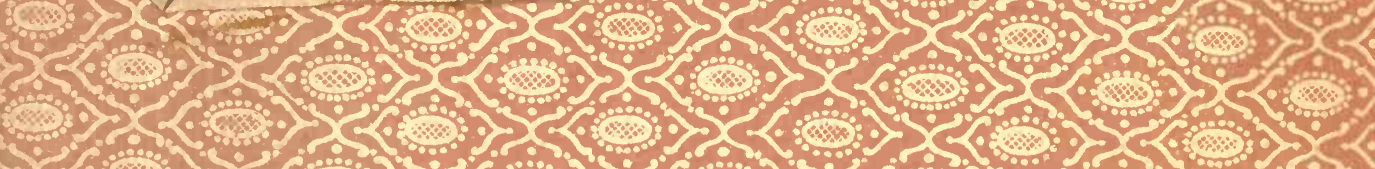

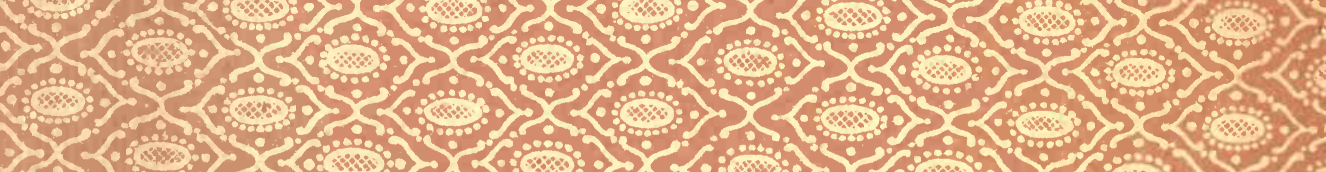

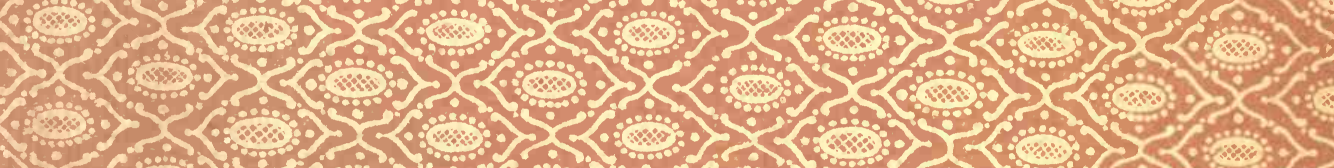

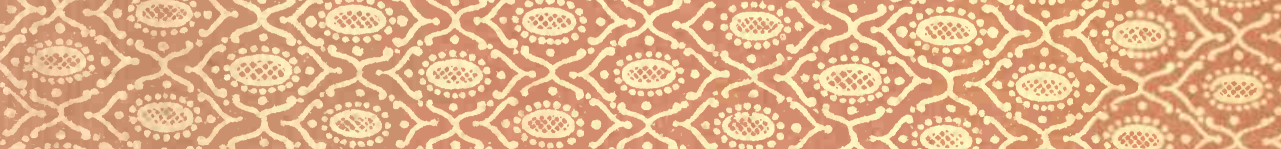

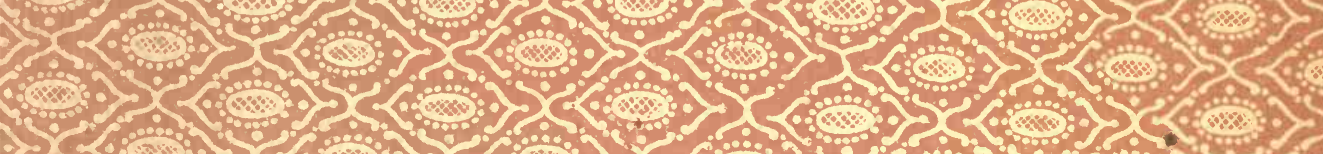

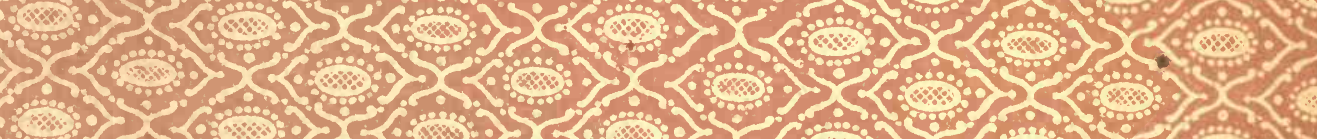
3.25
3

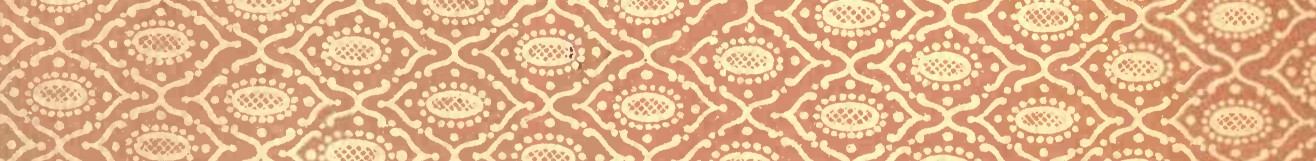

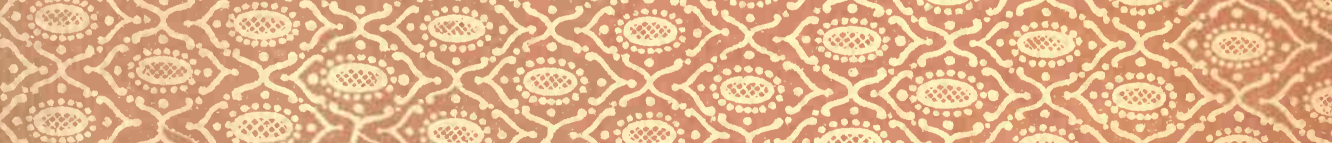

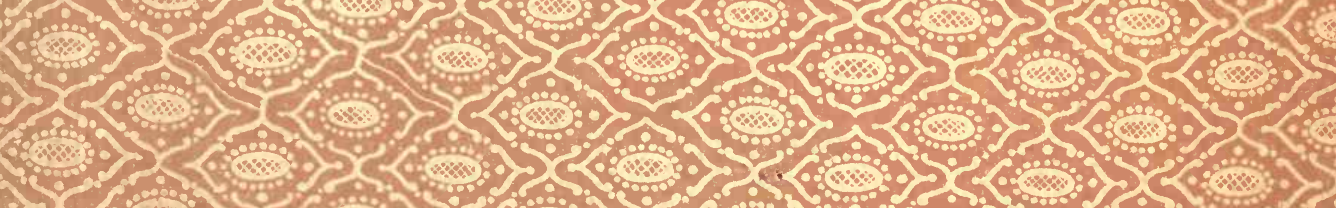

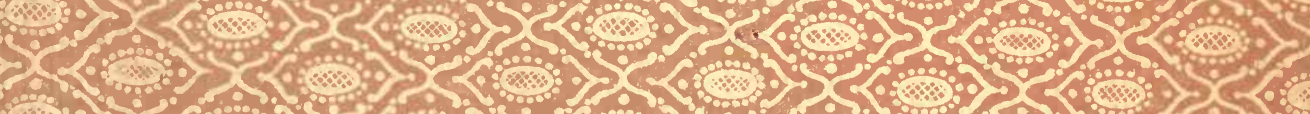

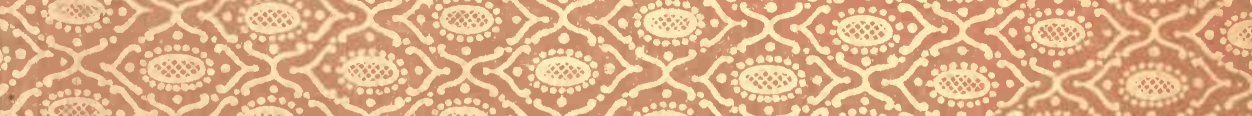

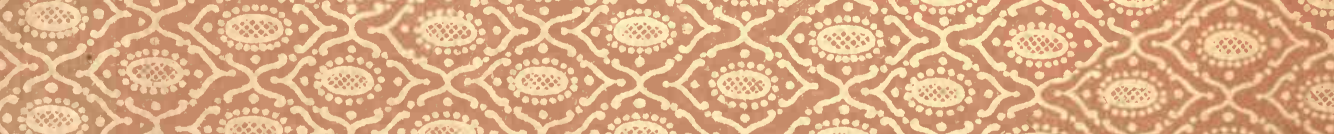

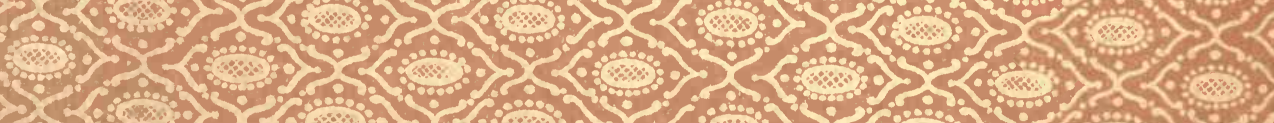

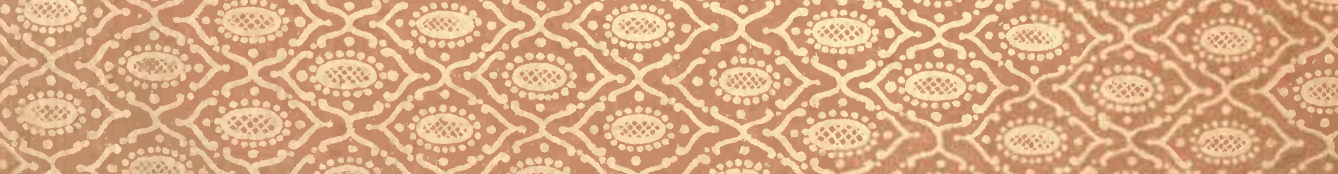


